\title{
Location-Dependent Mechanical Property Evaluation on Additively Manufacture Materials
}

Nuclear Science and Engineering Division 


\section{About Argonne National Laboratory}

Argonne is a U.S. Department of Energy laboratory managed by UChicago Argonne, LLC under contract DE-AC02-06CH11357. The Laboratory's main facility is outside Chicago, at 9700 South Cass Avenue, Argonne, Illinois 60439. For information about Argonne and its pioneering science and technology programs, see www.anl.gov.

\section{DOCUMENT AVAILABILITY}

Online Access: U.S. Department of Energy (DOE) reports produced after 1991 and a growing number of pre-1991 documents are available free at OSTI.GOV (http://www.osti.gov/), a service of the US Dept. of Energy's Office of Scientific and Technical Information.

Reports not in digital format may be purchased by the public from the National Technical Information Service (NTIS):

U.S. Department of Commerce

National Technical Information Service

5301 Shawnee Rd

Alexandria, VA 22312

www.ntis.gov

Phone: (800) 553-NTIS (6847) or (703) 605-6000

Fax: (703) 605-6900

Email: orders@ntis.gov

Reports not in digital format are available to DOE and DOE contractors from the Office of Scientific and Technical Information (OSTI):

U.S. Department of Energy

Office of Scientific and Technical Information

P.O. Box 62

Oak Ridge, TN 37831-0062

www.osti.gov

Phone: (865) 576-8401

Fax: (865) 576-5728

Email: reports@osti.gov

\section{Disclaimer}

This report was prepared as an account of work sponsored by an agency of the United States Government. Neither the United States Government nor any agency thereof, nor UChicago Argonne, LLC, nor any of their employees or officers, makes any warranty, express or implied, or assumes any legal liability or responsibility for the accuracy, completeness, or usefulness of any information, apparatus, product, or process disclosed, or represents that its use would not infringe privately owned rights. Reference herein to any specific commercial product, process, or service by trade name, trademark, manufacturer, or otherwise, does not necessarily constitute or imply its endorsement, recommendation, or favoring by the United States Government or any agency thereof. The views and opinions of document authors expressed herein do not necessarily state or reflect those of the United States Government or any agency thereof, Argonne National Laboratory, or UChicago Argonne, LLC. 


\section{Location-Dependent Mechanical Property Evaluation on Additively Manufacture Materials}

prepared by

Meimei Li, Wei-Ying Chen, Xuan Zhang, Florent Heidet

Nuclear Science and Engineering Division, Argonne National Laboratory

Edward J. Listwan, David L. Rink, Joseph T. Listwan

Experimental Operations and Facilities Division, Argonne National Laboratory

August 2021 


\title{
Location-Dependent Mechanical Property Evaluation on Additively Manufacture Materials
}

\author{
Meimei Li, Wei-Ying Chen, Xuan Zhang, Florent Heidet, Nuclear Science and Engineering \\ Division, Argonne National Laboratory \\ Edward J. Listwan, David L. Rink, Joseph T. Listwan, Experimental Operations and Facilities \\ Division, Argonne National Laboratory
}

\begin{abstract}
This report summarizes research activities conducted at Argonne National Laboratory in support of the development, qualification and certification of additively manufactured (AM) metallic components to allow for innovative reactor design and licensing for the Transformational Challenge Reactor (TCR). Focus is on the evaluation of high temperature mechanical properties including creep and fatigue of 316L stainless steel manufactured by the laser powder bed fusion process. Creep behavior of AM 316L stainless steel was evaluated for rods printed by either or a combination of both lasers of the dual-laser system of a Concept Laser-M2 printer to examine the consistency across the build plate. Creep tests were conducted at temperatures of 550, 575, 600, and $650^{\circ} \mathrm{C}$ and stresses between 175 and $300 \mathrm{MPa}$ using ASTM standard-sized specimens. The effect of heat treatments at different temperatures on creep properties of AM 316L SS was examined to understand the processing-microstructure-property relationship. Fatigue properties of AM 316L SS were investigated for two print geometries (rod and plate) and in two build orientations of printed plates. Locations of specimens in the build were carefully tracked such that the testing data can be directly related to location-specific in situ data to establish links between printing process, post-printing treatment, microstructure and mechanical properties. The work is to support the development of a digital platform informed approach to AM component qualification and certification for nuclear applications.
\end{abstract}

\section{Contents}

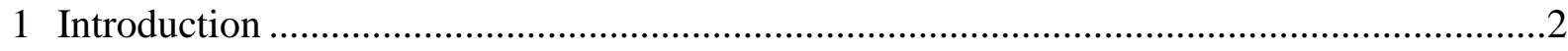

2 Creep Behavior of Printed Rods of AM 316L SS ……….................................................

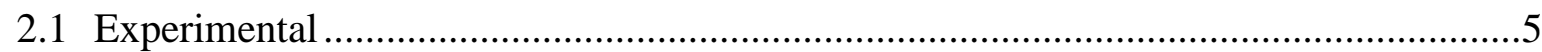

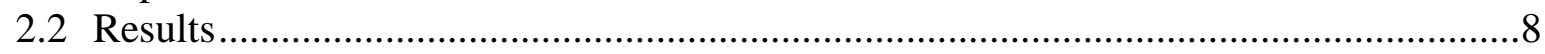

2.2.1 Creep Behavior of Printed Rods in the As-Built Condition ..................................

2.2.2 Microstructure of Printed Rods in the As-Built Condition ....................................11

2.2.3 Microstructural Evolution under Creep Loading ...............................................12

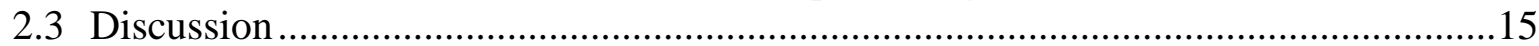

2.3.1 Creep Deformation Mechanism in AM 316L SS ..............................................15

2.3.2 Fracture Deformation Mechanism in AM 316L SS.............................................18

3 Effect of Heat Treatment on Creep Behavior of AM 316L SS ……………………….......20

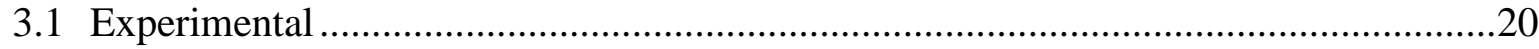




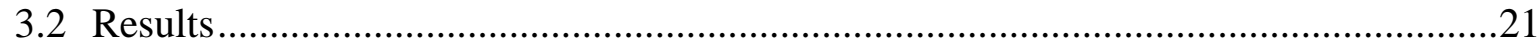

3.2.1 Creep Behavior of Heat-Treated Rod Specimens ...............................................21

3.2.2 Microstructure of Heat-Treated Rod Specimens ...................................................23

3.2.3 Microstructure of Heat-Treated Rod Specimens after Creep …………………...28

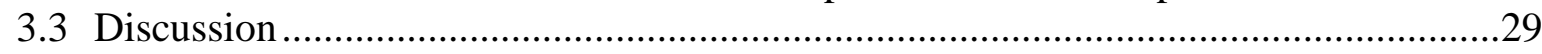

3.3.1 Effect of Post-Build Heat Treatment on Creep Bahvior of AM 316L SS ...........29

3.3.2 Effect of Post-Build Heat Treatment on Microstructure of AM 316L SS ............30

3.3.3 Effect of Heat Treatment on Creep Deformation Mechanism of AM 316L SS ..32

4 Fatigue Performation of Printed Rods and Plates of AM 316L SS .......................................35

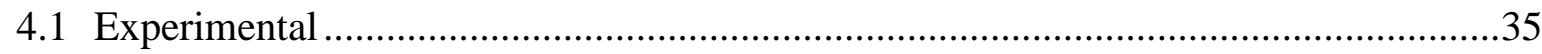

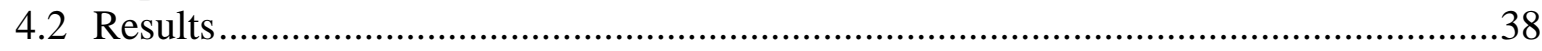

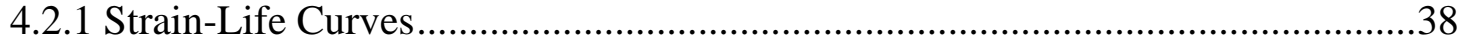

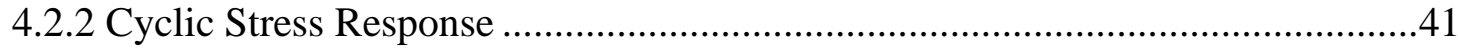

4.2.3 Microstructural Evolution under Cyclic Loading ..............................................43

5 Evolution of Tensile and Creep Properties of Printed Plates using Subsized Specimens....48

5.1 Experimental ................................................................................................

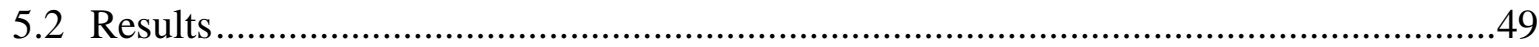

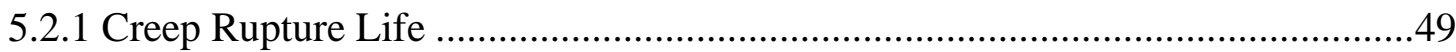

5.2.2 Tensile Stress-Strain Curves ……………………………………………....50

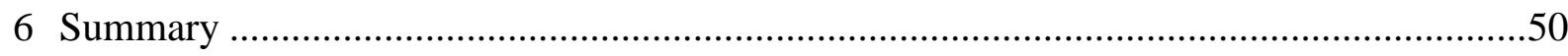

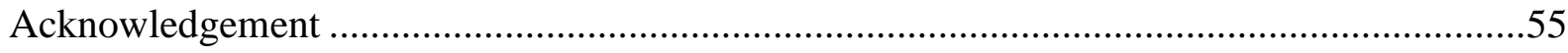

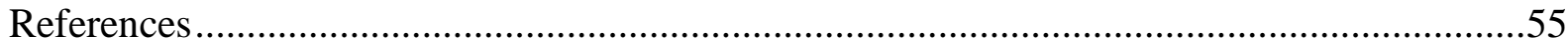

\section{Introduction}

Type 316 austenitic stainless steel has been widely used in various types of nuclear reactors, including current nuclear power plants and next-generation advanced reactor concepts. Additive manufacturing as a disruptive manufacturing technology has opened up unprecedented opportunities for designing components with controlled microstructure, enabling smart designs of reactor components with complex geometries, design freedom and possibly enhanced performance [1]. Previous studies have shown that additively-manufactured 316L stainless steel (AM 316L SS) has considerably improved low-temperature tensile strength and good ductility but inferior creep resistance over conventionally-made wrought 316 SS [2-5]. The hightemperature mechanical performance of AM 316L SS, e.g. creep, fatigue and creep-fatigue must be thoroughly investigated for its applications in the Transformational Challenge Reactor (TCR), a gas-cooled microreactor being developed to demonstrate revolutionary technologies including additive manufacturing [6,7].

Laser powder bed fusion (LPBF), a metal additive manufacturing technology, uses laser beams to melt and consolidate metal powder lay-by-layer to form parts. It can fabricate complex components with high accuracy that is difficult to achieve by conventional manufacturing 
techniques, e.g. casting and forging. This new manufacturing technology has seen broad applications in a wide range of industries and is now routinely used to process austenitic stainless steels [8-10]. The microstructure of LPBF-produced 316L SS is, however, much more complex than that of conventionally-made 316 SS due to the high energy input and the rapid melting and solidification process. Various types of defects can be produced during the printing process, such as pores, cracks, and high residual stresses [10-14]. A highly non-equilibrium, heterogenous microstructure spanning multiple length scales was observed in 316L SS produced by LPBF, e.g. columnar grains within melt pools, subgranular cellular structures, high density dislocations within cell walls, boundary elemental segregation, and oxide particles distributed both at boundaries and in the matrix [15-18]. Post-build heat treatments are performed to relieve residual stresses and to produce desired microstructure and improved mechanical properties [19-28].

A number of studies have been carried out to understand the fundamental strengthening mechanisms and the roles of porosity, dislocation cell size, dislocation density, elemental segregation, and particles in the strength of AM 316L SS [2,4,5,17,27,29-33]. The lowtemperature high strength and good ductility of AM 316L SS has been attributed to dislocation cell structures formed during printing. Some studies suggest that the cell spacing is the key microstructural parameter controlling the strength of the AM 316L SS [17, 27,30]. Our earlier work has also shown that the creep rate of the AM 316L SS can be directly related to the dislocation cell size in the alloy [5]. Thermal annealing at high temperature can cause thermal instability of the microstructure of the as-built AM 316L SS. Several studies have shown that the hardness and room-temperature yield stress drop continuously with increasing annealing temperatures above $600^{\circ} \mathrm{C}$, and this strength reduction has been primarily attributed to the coarsening of cell structures [20-22, 27]. The variations of the as-built microstructure resulting from the variations in processing conditions, feedstock, or even printer types also complicate the understanding of the thermal stability of the microstructure of AM 316L SS. More importantly, few studies have been carried out to evaluate the high-temperature mechanical properties, e.g. creep, fatigue, and creep-fatigue and the roles of printing defects and unique microstructure of AM 316L SS in controlling the high temperature performance of AM components.

It has been broadly recognized that evaluation of the mechanical properties of AM components is challenging due to many variables involved in the manufacturing process. Thermal history of the part varies with laser power, laser scanning speed, layer height, laser spot size, scanning strategy, etc., making it difficult to compare the microstructure and mechanical properties of AM components. Even if processing parameters are kept constant, the thermal history of a part will be affected by the part geometry, e.g. rods vs. plates. Build orientation has also been found to have a strong effect on the mechanical properties of AM components due to their heterogeneous microstructure and uneven defect patterns and configurations. The "local" building orientation must be taken into account in the design process, particularly at locations of high local stress and strain concentrations. For accelerated qualification and certification of AM components, it is imperative that the testing datasets be tracked to specific locations and directly related to location-specific in situ data to establish robust processing - microstructure - property relationships. 
This report summarizes the findings of creep and fatigue behavior of AM 316L SS manufactured by the laser powder bed fusion process. AM316L SS in two different print geometries, namely, rod and plate, and two different build orientation, i.e. horizontal and vertical in terms of build direction relative to loading direction, was investigated, and specimen locations in the build were closely tracked such that the testing data can be directly related to locationspecific in situ data to establish links between printing process, post-printing treatment, microstructure and mechanical properties. The effect of heat treatments at different temperatures on creep properties was also investigated to understand the processing-microstructure-property relationship of AM 316L SS. 


\section{Creep Behavior of Printed Rods of AM 316L SS}

\subsection{Experimental}

Creep specimens were ASTM standard-sized round bar specimens. Specimens were fabricated from rods of Builds 20190308M2 and 20190315M2 of AM 316L SS printed by a laser powder bed fusion process using a Concept Laser-M2 printer at Oak Ridge National Laboratory [34]. Praxair 316L stainless steel powder and default printer settings were used for printing. The chemical composition of $316 \mathrm{~L}$ feedstock is given in Table 2-1.

The Concept Laser - M2 printer uses two identical laser systems in different regions of the powder bed to fabricate larger components. Rods used to fabricate creep specimens were printed by laser 1, laser 2 or two lasers, as shown in Fig. 2-1. Printed rods had a nominal diameter of 0.5 " and a nominal length of 4.125 ". They were printed vertically, and the ID of the rod was printed at the top end of the rod to keep track of the rod locations (Fig. 2-2 [5]). Creep specimens had a nominal gauge diameter of 0.25 ", a nominal gauge length of $1.25 \%$, and a total length of 3.60". One specimen per rod was machined. The axial direction of the specimen was along the build direction. To keep track of the exact location and the build direction of the specimen, the top of the upper grip section of the specimen was the top of the printed rod, and the upper grip section was designed to be 0.08 " longer than the lower grip section of the specimen (Fig. 2-2).

Specimens machined from rods of Build 20190315M2 had the same IDs as the rods. If rods were printed by laser 1, they were assigned IDs of L1-X where "L1" refers to "Laser 1" and "X" refers to the location in the build. Specimens fabricated from these rods are called "Laser 1 specimens" in this report. Specimens machined from rods printed by laser 2 had IDs of L2-X where "L2" refers to "Laser 2", "X" refers to the location in the build, and the specimens are called "Laser 2 specimens". Specimens machined from rods printed by both lasers were assigned IDs of S-X and are called "2-Laser specimens". Rods of Build 20190308M2 had no unique IDs. Rods printed by Laser 1 were labeled as "L1", and specimens were assigned IDs of "L1XX"; rods printed by Laser 2 were labeled as "L2", and specimens were assigned IDs of "L2XX". This dual-laser system enables a direct one-to-one batch variability within a single build while holding all other variables constant.

Creep tests were conducted at four temperatures, 550, 575, 600, and $650^{\circ} \mathrm{C}(0.49-0.55$ $\mathrm{T}_{\mathrm{m}}$, where $\mathrm{T}_{\mathrm{m}}$ is the melting point of Type $316 \mathrm{SS}$ ) and stresses between 175 and $300 \mathrm{MPa}$ in air. Several Laser 1 and Laser 2 specimens were tested under the same temperature and stress conditions to evaluate the consistency across the build plate. Table 2-2 lists the creep specimen information and test conditions.

Creep tests were conducted according to ASTM Standard E139-11, "Standard Test Methods for Conducting Creep, Creep-Rupture, and Stress-Rupture Tests on Metallic Materials." Tests were carried out on ATS Series 2300 Lever Arm Creep Testing Systems integrated with WinCCS II computer control and data acquisition software package. Each creep frame was equipped with a three-zone split-tube furnace capable of operation up to $1100^{\circ} \mathrm{C}$. All specimens were soaked at the test temperature for 1 hour prior to loading to ensure a stable test temperature. The temperature was monitored by 2 thermocouples with each attached to the grip shoulder section of the specimen. The temperature was maintained to a total variance of $\pm 1^{\circ} \mathrm{C}$. Creep strain 
was monitored by an averaging extensometer frame mounted on opposite sides of the specimen, and creep strain was calculated using the specimen nominal gauge length. All the specimens were tested to rupture. The creep elongation was calculated using the original adjusted gauge length of the reduced section of the specimen.

The microstructure of the as-built specimen was examined non-destructively before the creep test by synchrotron high-energy X-ray tomography at the beamline 1-ID at the Advanced Photon Source (APS) at Argonne National Laboratory. Porosity distribution was measured at the gauge section of the specimen by scanning the middle section of the gauge with an X-ray energy of $81 \mathrm{keV}$ and a pixel size of $1.172 \mu \mathrm{m}$. The microstructure of the as-built specimen was also examined destructively, using the bottom section of a printed rod. A thin sheet ( 250 $\mu \mathrm{m}$ thick) was sectioned, and disk specimens of $3 \mathrm{~mm}$ in diameter were punched from the thin sheet for transmission electron microscopy (TEM). After creep tests, gauge sections of broken halves were examined by synchrotron high-energy X-ray tomography at the APS. Metallographic specimens were prepared in the axial direction of the gauge of the other half of the fractured specimen to examine the creep fracture mode by optical microscopy. To examine the microstructure of creeptested specimens by TEM, disk specimens of $3 \mathrm{~mm}$ in diameter were cut from the gauge section away from the fracture surface of a specimen. TEM disk specimens were electropolished to perforation using an electrolyte of $95 \%$ methanol and $5 \%$ perchloric acid at $\sim-40^{\circ} \mathrm{C}$. Electropolishing of TEM disks was a challenge due to the presence of cracks and voids in the creep tested specimen. Electropolished thin foil specimens were further ion milled to obtain appreciable thin areas for TEM examination. TEM and EDS were conducted to examine dislocations, subgrains, second-phase precipitates and solute segregations on a FEI Tecnai F20ST TEM and a FEI Talos F200X TEM in the Center for Nanoscale Materials (CNM) at Argonne National Laboratory.

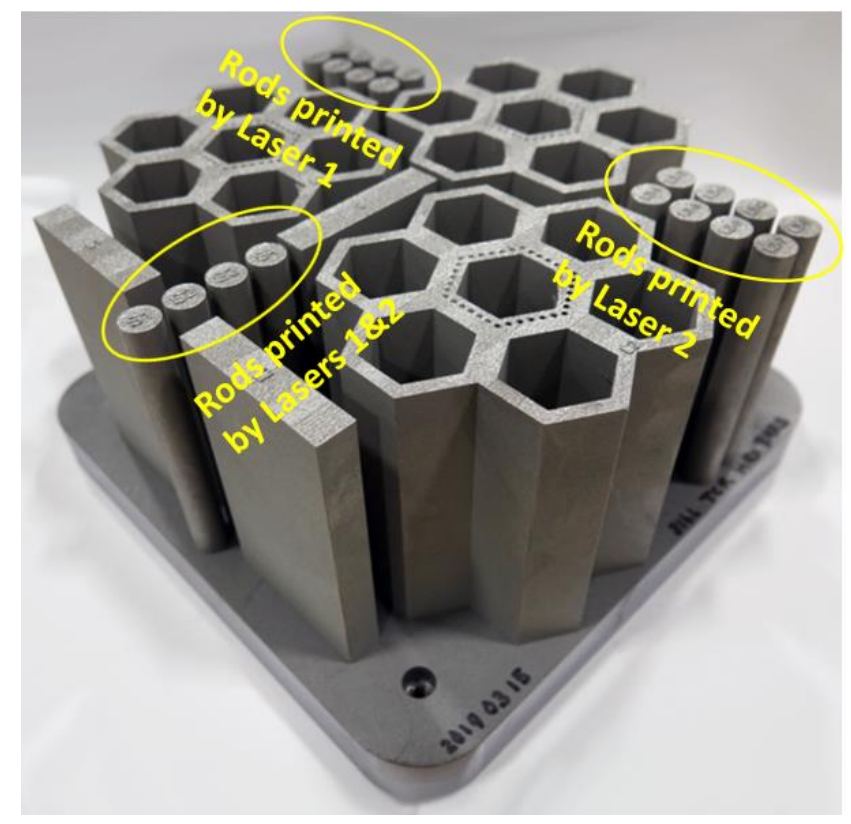

Figure 2-1. Build 20190315 showing the orientation and locations of rods printed by Laser 1, Laser 2, or both lasers. 

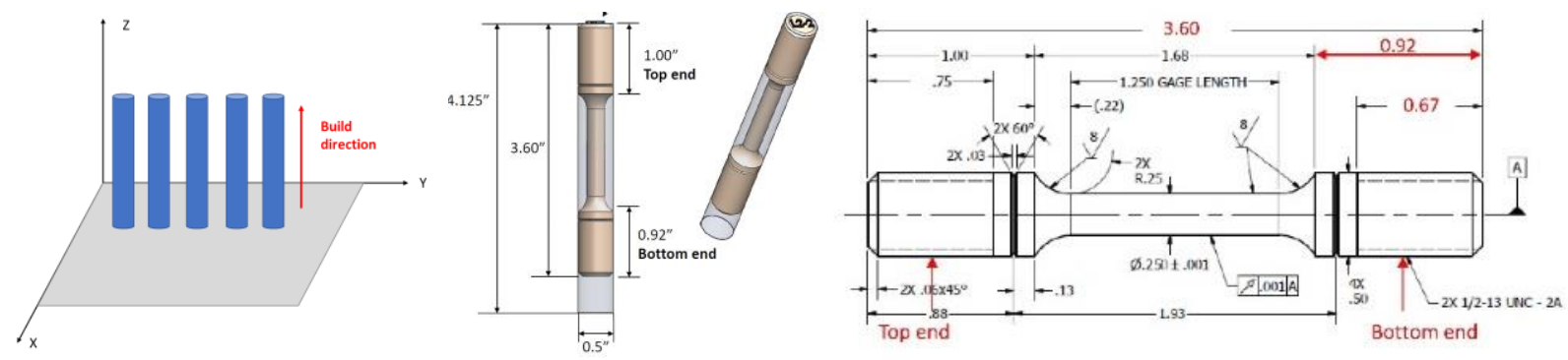

Figure 2-2. Specimen fabrication and orientation drawings (all dimensions are in inches) [5].

Table 2-1: Composition of the Praxair 316L stainless steel powder (wt\%).

\begin{tabular}{|l|l|l|l|l|l|l|l|l|l|l|l|}
\hline Fe & Cr & Ni & Mo & Mn & Si & N & Cu & Co & C & P & O \\
\hline Bal. & 17.07 & 12.08 & 2.41 & 1.19 & 0.46 & 0.01 & 0.01 & 0.1 & 0.006 & $<0.005$ & 0.05 \\
\hline
\end{tabular}

Table 2-2: List of creep rod specimens and testing conditions.

\begin{tabular}{|c|c|c|c|c|c|c|}
\hline $\begin{array}{l}\text { Specimen } \\
\text { ID }\end{array}$ & Build ID & Rod ID & $\begin{array}{l}\text { Laser } \\
\text { mode }\end{array}$ & Condition & $\begin{array}{c}\text { Test Temp } \\
\left({ }^{\circ} \mathrm{C}\right)\end{array}$ & $\begin{array}{l}\text { Stress } \\
(\mathrm{MPa})\end{array}$ \\
\hline L101 & 20190308M2 & L1 & Laser 1 & As-built & 650 & 225 \\
\hline L102 & $20190308 \mathrm{M} 2$ & L1 & Laser 1 & As-built & 650 & 200 \\
\hline L103 & 20190308M2 & L1 & Laser 1 & As-built & 650 & 175 \\
\hline L201 & 20190308M2 & L2 & Laser 2 & As-built & 650 & 225 \\
\hline L202 & $20190308 \mathrm{M} 2$ & L2 & Laser 2 & As-built & 650 & 200 \\
\hline L203 & 20190308M2 & L2 & Laser 2 & As-built & 650 & 175 \\
\hline L1-1 & $20190315 \mathrm{M} 2$ & L1-1 & Laser 1 & As-built & 600 & 200 \\
\hline L1-2 & $20190315 \mathrm{M} 2$ & L1-2 & Laser 1 & As-built & 600 & 225 \\
\hline L1-3 & $20190315 \mathrm{M} 2$ & L1-3 & Laser 1 & As-built & 600 & 250 \\
\hline S-1 & $20190315 \mathrm{M} 2$ & S-1 & Laser $1 \& 2$ & As-built & 575 & 200 \\
\hline$S-2$ & $20190315 \mathrm{M} 2$ & S-2 & Laser $1 \& 2$ & As-built & 575 & 225 \\
\hline S-3 & $20190315 \mathrm{M} 2$ & S-4 & Laser $1 \& 2$ & As-built & 575 & 250 \\
\hline L2-1 & $20190315 \mathrm{M} 2$ & L2-1 & Laser 2 & As-built & 550 & 300 \\
\hline L2-2 & $20190315 \mathrm{M} 2$ & L2-2 & Laser 2 & As-built & 550 & 250 \\
\hline L104 & 20190308M2 & L1 & Laser 1 & As-built & 550 & 275 \\
\hline L204 & 20190308M2 & L2 & Laser 2 & As-built & 550 & 275 \\
\hline
\end{tabular}




\subsection{Results}

\subsubsection{Creep Behavior of Printed Rods in the As-Built Condition}

Figure 2-3 shows the creep curves in terms of creep strain as a function of time for AM $316 \mathrm{~L} \mathrm{SS}$ tested at 550,600 , and $650^{\circ} \mathrm{C}$ [5]. The creep rupture data at 550, 575, 600, and $650^{\circ} \mathrm{C}$ is plotted in Fig. 2-4 in terms of the creep stress vs. the rupture time. Laser 1, Laser 2, and 2Laser specimens show comparable creep behavior. The batch variability of these specimens is insignificant in these short-term creep tests.

The Larson-Miller plot is given in Fig. 2-5. The creep data of the as-built AM 316L SS are compared with the literature data for conventionally-made 316 SS (CM 316 SS) [35,36]. The Larson-Miller parameter, $T\left(C+\log 10\left(t_{f}\right)\right)$ was calculated using $\mathrm{C}=17$ for both AM 316L SS and CM 316 SS. The creep data of all the specimens can be described by a single Larson-Miller plot. Relative to CM 316 SS, AM 316L SS has an inferior creep rupture strength. It should be noted that the carbon contents are significantly different in AM 316L SS and in CM 316 SS reported in the literature: the carbon concentration of 316L SS powder was $0.006 \%$, while Sasikala et al reported a carbon concentration of $0.048 \%$ in a CM 316 SS [35]. The data of CM 316 SS in [36] were derived from the $550^{\circ} \mathrm{C}$ and $600^{\circ} \mathrm{C}$ rupture equations developed by Oak Ridge National Laboratory, which represent the average behavior of Type 316 SS. The extremely low carbon content in AM 316L SS can be an important factor affecting the creep rupture strength, and the difference in carbon concentration between AM 316L SS investigated here and CM 316 SS reported in the literature complicates the comparison of creep properties of AM 316L SS and CM $316 \mathrm{SS}$.

All the creep tests of as-built AM 316L SS showed a very short primary and secondary creep followed by a continued increase in creep rate until failure, and the creep curves were dominated by accelerated creep, as shown in Fig. 2-3. The minimum creep rate was achieved at the early stage of the test, typically at a creep strain of $<1 \%$. The minimum creep rate was measured in the strain range of $0.2-0.6 \%$ for each test, and the data of the minimum creep rate is plotted as a function of the applied stress in Fig. 2-6. The minimum creep rate follows a power law relationship with the applied stress with a high stress exponent, which implies dislocation creep mechanisms. 


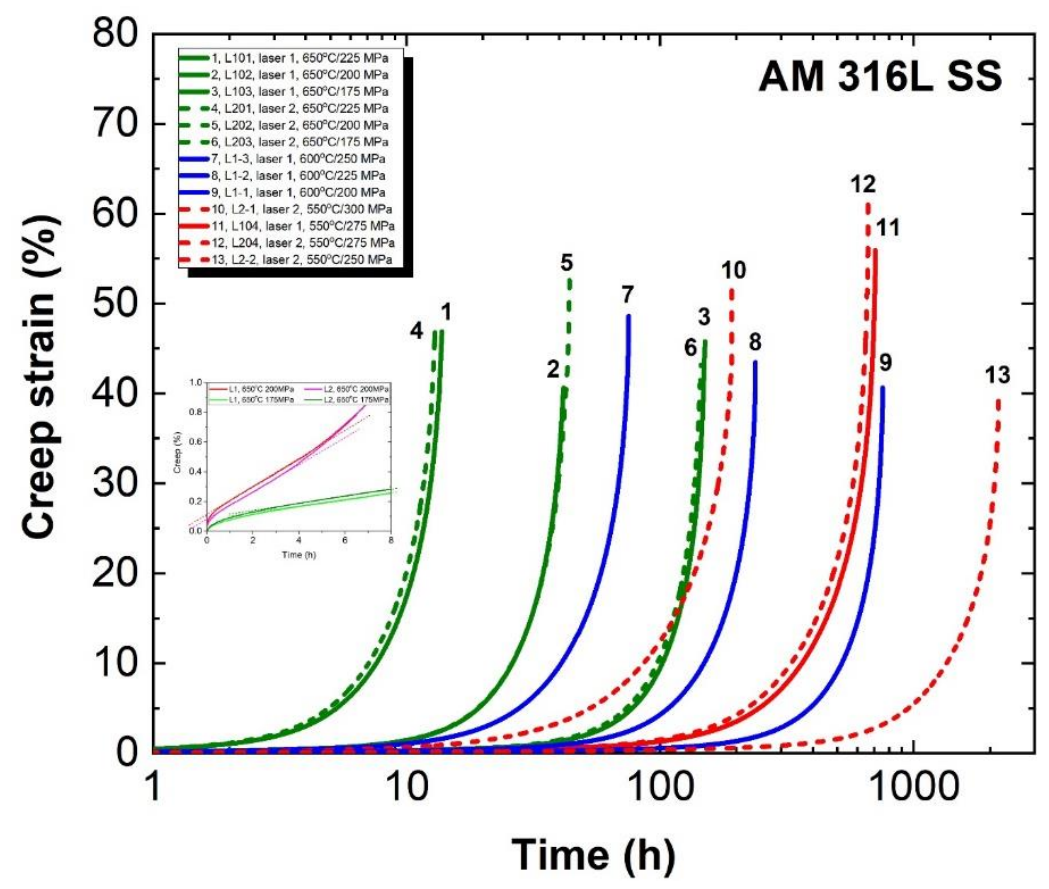

Figure 2-3. Creep strain as a function of time for AM 316L SS tested at 550, 600 and $650^{\circ} \mathrm{C}$. The insert shows the initial portions of several representative creep strain - time curves to illustrate the secondary creep of the curve [5].

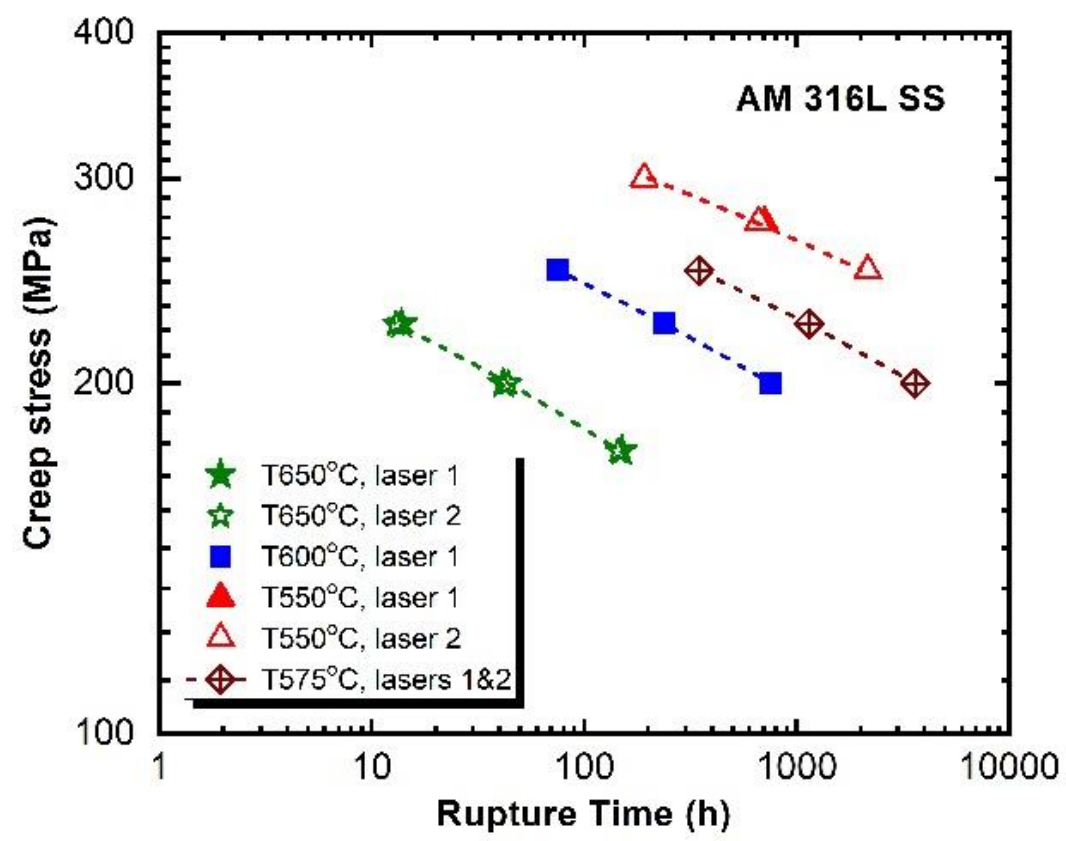

Figure 2-4. Stress-rupture life plot at $550,575,600$ and $650^{\circ} \mathrm{C}$ for AM $316 \mathrm{~L}$ SS. 


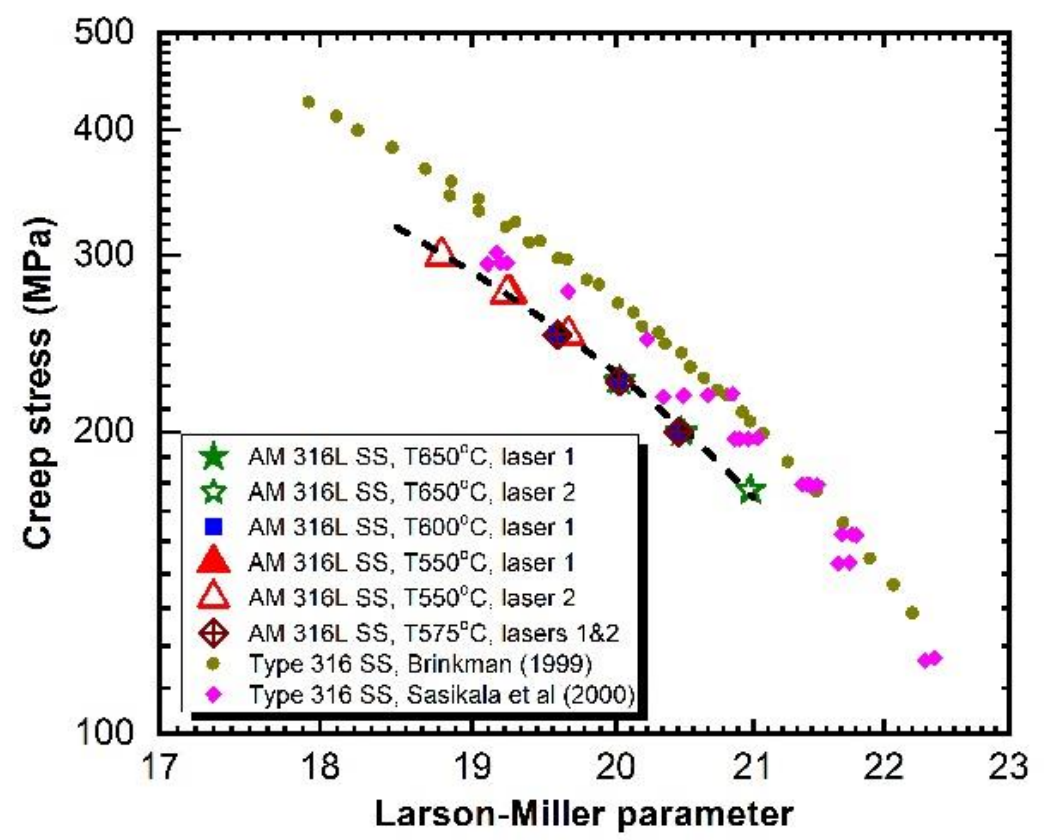

Figure 2-5. Larson-Miller plot for AM 316L SS tested at 550, 575, 600, and $650^{\circ} \mathrm{C}$.

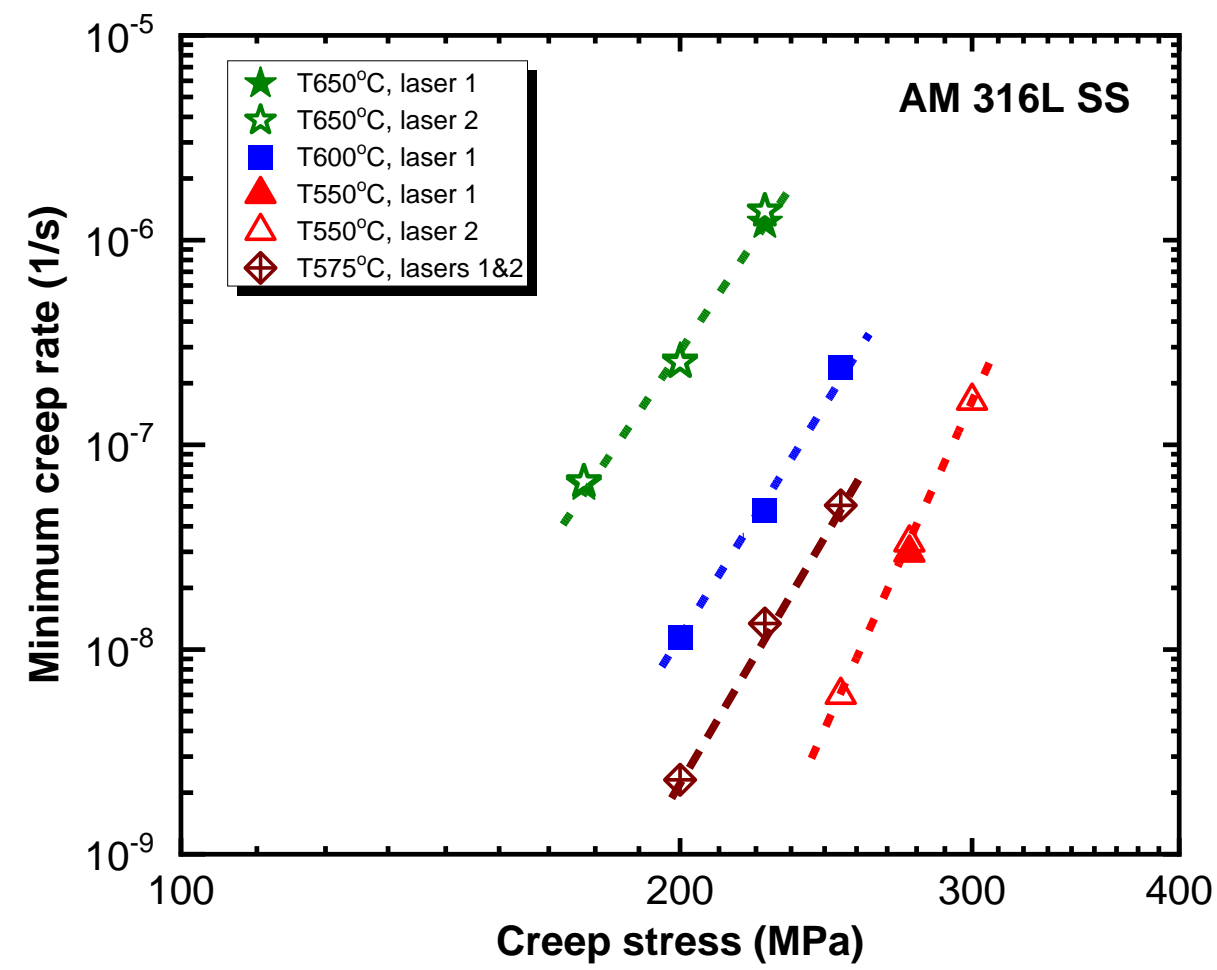

Figure 2-6. Minimum creep strain rates vs. creep stress for AM 316L SS tested at 550, 575, 600, and $650^{\circ} \mathrm{C}$. 


\subsubsection{Microstructure of Printed Rods in the As-Built Condition}

The microstructure of the as-built AM 316L SS was examined by TEM and is shown in Fig. 2-7 [5]. TEM images at various magnifications in Fig. 2-7(a) reveal well-organized dislocation cell structure with the mean cell size (width) of $530 \pm 62 \mathrm{~nm}$. The dislocation density is low inside the cells. Minimal misorientations were observed between dislocation substructures, and cell walls consisted of dislocation tangles. Particles were distributed both at boundaries and within cells. EDS elemental maps (Fig. 2-7(b)) reveal that these particles are oxides enriched in Si, Mn. The mean size of oxide particles is $25 \pm 9 \mathrm{~nm}$. Elemental segregation was also observed at cell boundaries which were enriched in $\mathrm{Cr}$ and Mo and depleted of Fe. These observations are consistent with the findings reported in the literature.
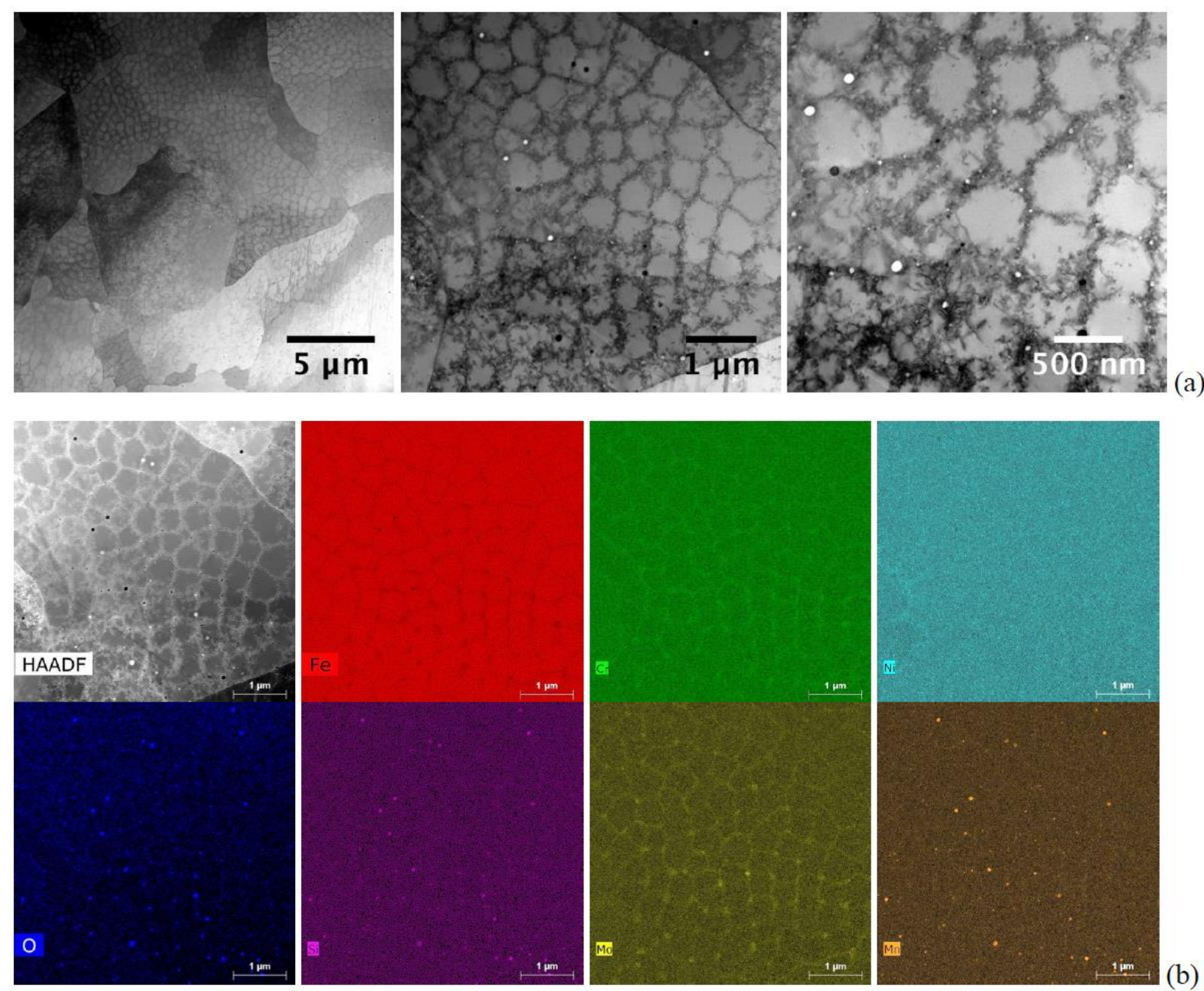

(a)

Figure 2-7. (a) Bright-field STEM micrographs at different magnifications showing dislocation cell structure and particles at boundaries; (b) HAADF micrograph and EDS elemental maps showing oxide particles and elemental segregation at boundaries in the as-built AM 316 L SS

[5]. 
X-ray tomography was conducted to reveal porosity in a printed rod. Figure 2-8(a) [5] shows $3 \mathrm{D}$ visualization of porosity across the entire cross section at the gauge midline of a rod creep specimen. The porosity in this volume is $0.10 \%$ with the mean size of $7.72 \pm 0.08 \mu \mathrm{m}$. It should be noted that pores with size $<2 \mu \mathrm{m}$ (which is the resolution limit) were not counted. Large pores were observed primarily near the centerline of the gauge and along the radial direction at given angles. Fig. 2-8(b) [5] is 3D visualization of a smaller cross-sectional area with a larger thickness in the central region of the gauge showing segregated larger pores. The porosity in this smaller volume is $0.18 \%$. Large pores have irregular shapes rather than spherical.

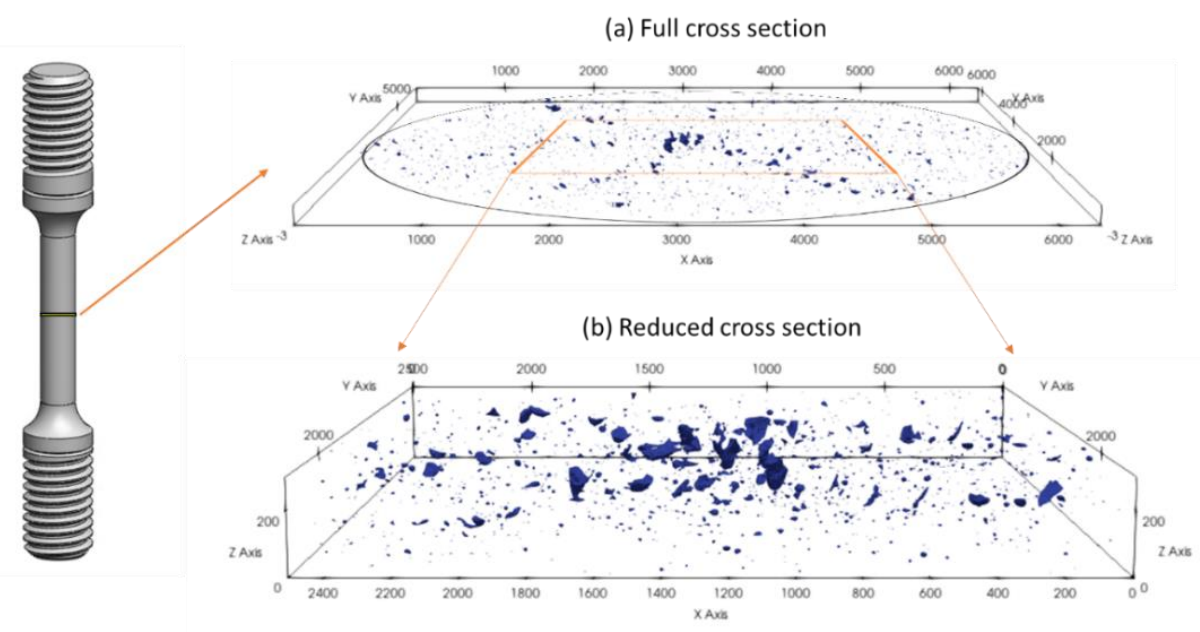

Figure 2-8. 3D visualization of porosity (a) the full cross section and (b) the reduced cross section of the gauge of an AM316L SS specimen. The Z-axis is the build direction (axial label in pixel, 1 pixel $=1.172 \mu \mathrm{m}$ ) [5].

\subsubsection{Microstructural Evolution under Creep Loading}

Microstructure of the creep-tested specimens was examined by optical microscopy and TEM. Figure 2-9 shows the microstructure of as-built AM 316L SS after thermal exposure at $650^{\circ} \mathrm{C}$ for $14 \mathrm{~h}$ [5]. The metallographic specimen was taken from the grip section of the specimen after creep test at $650^{\circ} \mathrm{C}$ and $225 \mathrm{MPa}$ of which had a rupture life of $14 \mathrm{~h}$. The specimen shows a layered structure characterized by melt pool boundaries. Within the melt pool, columnar grains grow in the build direction, as shown in the axial view of Fig. 2-9. The grain size in the cross section is $\sim 20-30 \mu \mathrm{m}$. Defects, e.g. lack of fusion and gas pores, are evident in Fig. 2-9, consistent with the observation by X-ray tomography prior to creep.

Creep damage was characterized by optical microscopy. Metallographic specimens were taken in the gauge section in the longitudinal direction. Figure 2-10 compares the specimens of AM 316L SS and wrought $316 \mathrm{H}$ SS tested under the same creep condition, $650^{\circ} \mathrm{C} 225 \mathrm{MPa}$ [5]. Grain boundary cracking is the dominant failure mode in both specimens. Grains are highly elongated, and cracks grow primarily along the grain boundaries perpendicular to the loading direction. AM 316L SS shows a few large cracks mixed with a high density of microcracks dispersed at grain boundaries, while wrought $316 \mathrm{H}$ SS shows relatively uniform, significant 
intergranular cracking. It should be noted that the grain structure of AM 316L SS is significantly different from that of wrought solution-annealed 316H SS which consists of equiaxed grains.
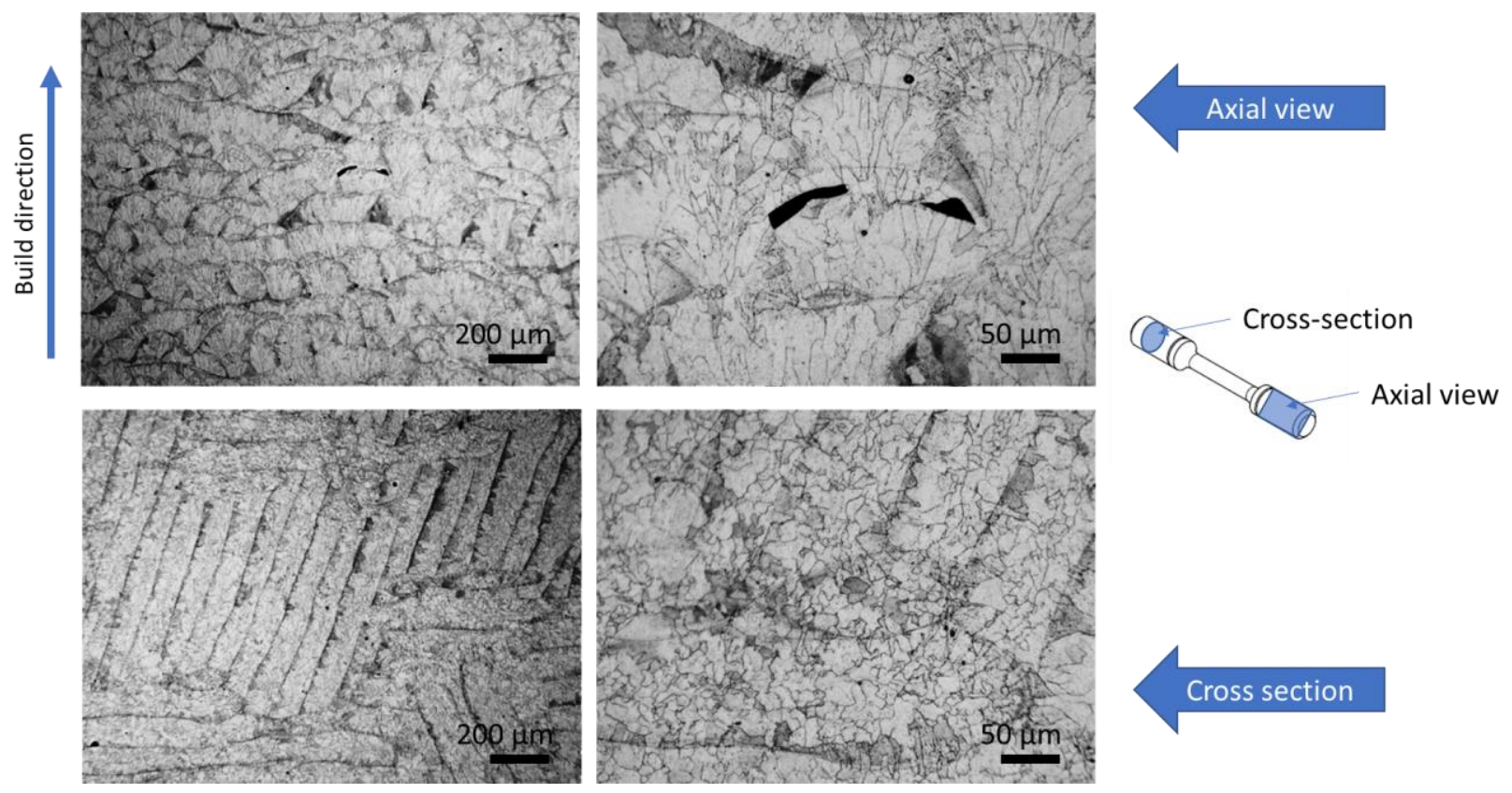

Figure 2-9. Optical images showing the microstructure of AM 316L SS after thermal exposure at $650^{\circ} \mathrm{C}$ for $14 \mathrm{~h}$ in the build direction (axial view) and cross section. Specimen was taken from the grip section of the specimen after creep test at $650^{\circ} \mathrm{C} 225 \mathrm{MPa}$ [5].
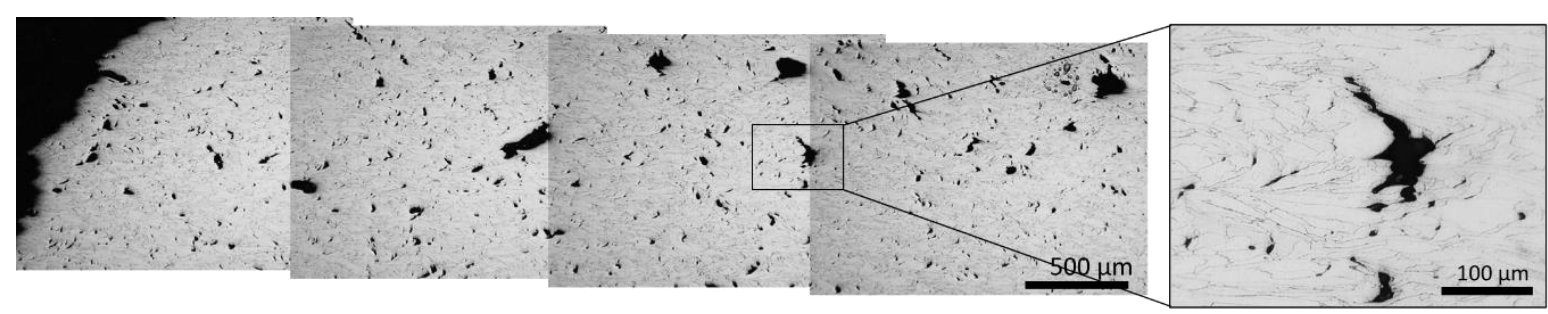

(a)
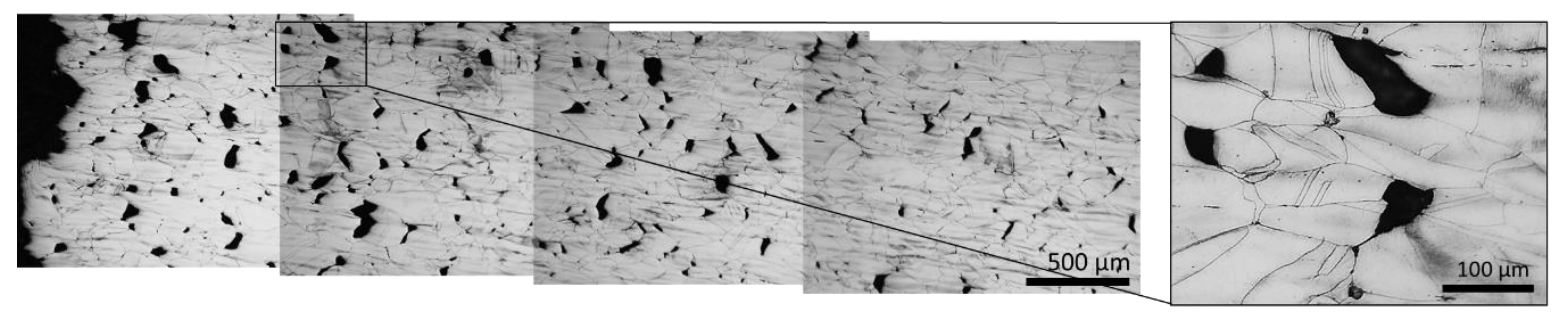

(b)

Figure 2-10. Optical micrographs of the gauge section of the creep tested specimens showing intergranular creep fracture (a) AM $316 \mathrm{~L} \mathrm{SS}$ and (b) wrought $316 \mathrm{H} \mathrm{SS}$ after creep test at $650^{\circ} \mathrm{C}$ $225 \mathrm{MPa}[5]$. 
Microstructure of creep-tested specimens was also examined by TEM, and is shown in Fig. 2-11 [5]. Figs. 2-11(a), (b) and (c) each contain two images taken at different areas of the same specimen. The left images of Figs.2-11 (a) and (b) show residual dislocation cells in the creeptested specimens. It was found that the initial dislocation cell structure in the as-built AM 316L SS disappeared during creep and evolved into a uniformly-distributed high-density dislocation structure, as shown in the right images of Figs. 2-11 (a) and (b). Two AM 316L SS specimens tested in different creep conditions, $550^{\circ} \mathrm{C} / 275 \mathrm{MPa}$ and $650^{\circ} \mathrm{C} / 225 \mathrm{MPa}$, respectively show similar microstructure after creep. Residual cells were still observable in limited areas in both specimens. Dislocation structure can vary considerably among individual grains of the same specimen under creep. Variations in the high stress specimen of 316 SS are highly dependent on grain orientations. The residual dislocation cell structure observed in the AM 316L SS creep specimens may be understood by the dependence of dislocation substructure on grain orientation. It was also observed that the residual dislocation cells in the creep-tested specimens were smaller than the dislocation cells in the as-built specimen $(530 \pm 62 \mathrm{~nm})$. A mean size of $382 \pm 54 \mathrm{~nm}$ was measured in the $650^{\circ} \mathrm{C} / 225 \mathrm{MPa}$ specimen, and $334 \pm 72 \mathrm{~nm}$ in the $550^{\circ} \mathrm{C} / 275 \mathrm{MPa}$ specimen in the limited areas studied by TEM.

Figure 2-11(c) shows the microstructure of the solution-annealed wrought $316 \mathrm{H}$ SS creeptested under the same condition $\left(650^{\circ} \mathrm{C} 225 \mathrm{MPa}\right)$ as the AM 316L SS specimen shown in Fig. 211(b). Wrought 316H SS also shows a uniform dislocation structure, similar to AM 316L SS after creep. It should be noted that $316 \mathrm{H} \mathrm{SS}$ had a dramatically different initial microstructure from AM 316L SS, which had a low dislocation density before creep.
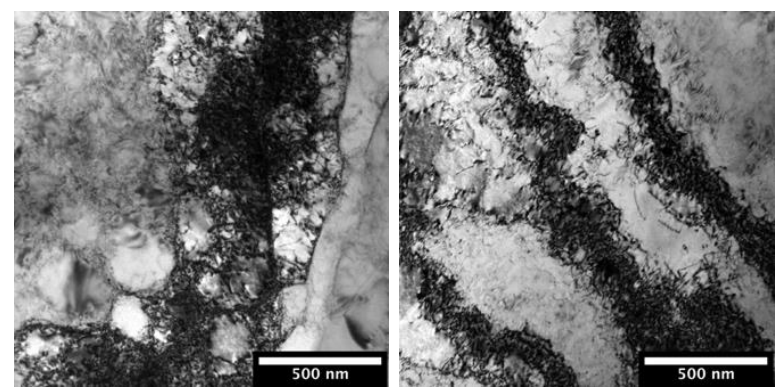

(a)
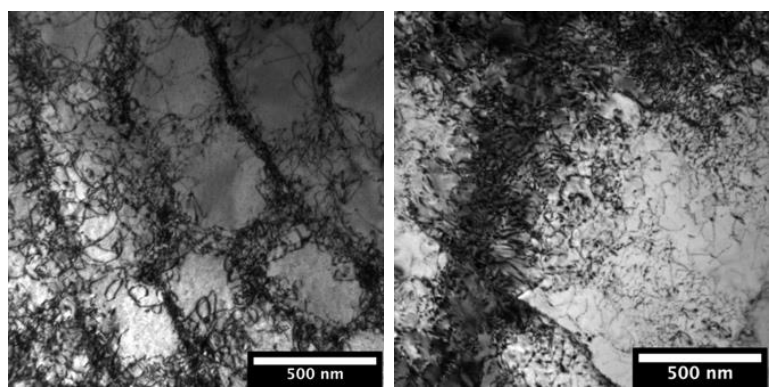

(b)
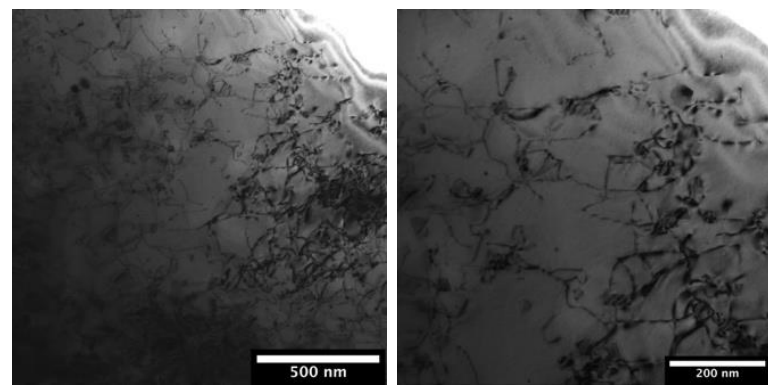

(c)

Figure 2-11. TEM micrographs showing the microstructure of the as-built AM $316 \mathrm{~L}$ SS after creep test at (a) $550^{\circ} \mathrm{C} / 275 \mathrm{MPa}$ and (b) $650^{\circ} \mathrm{C} / 225 \mathrm{MPa}$, (c) microstructure of wrought $316 \mathrm{H} \mathrm{SS}$ after creep test at $650^{\circ} \mathrm{C} / 225 \mathrm{MPa}$. The image conditions are: (a) $\mathrm{g}=200$ at 001 zone (left) and $\mathrm{g}$ $=111$ at $\overline{1} 10$ zone (right). (b) $\mathrm{g}=200$ at 001 zone (left) and $\mathrm{g}=200$ at 011 zone (right). (c) Both are $\mathrm{g}=200$ at 011 zone [5]. 


\subsection{Discussion}

\subsection{1. $\quad$ Creep Deformation Mechanism in AM 316L SS}

The creep rate of a material can be generally described by the following equation [44]:

$$
\dot{\varepsilon}=A \frac{D G b}{k T}\left(\frac{\sigma}{G}\right)^{n}
$$

where $\mathrm{A}$ is the constant, $\mathrm{D}$ the diffusion coefficient, $\mathrm{G}$ the shear modulus, $\mathrm{k}$ the Boltzmann constant, $\mathrm{T}$ the absolute temperature, $\mathrm{b}$ the Burgers vector, $\sigma$ the stress, and $\mathrm{n}$ the stress exponent. The diffusivity and elastic modulus are the two most important factors affecting the creep rate of a material at a given stress [45]. The minimum creep rate data in Fig. 2-6 are replotted in Fig. 212 where the creep rate is normalized by the self-diffusion coefficient, D and the stress normalized by the shear modulus, G. The values of $D$ and temperature-dependent $G$ were taken from [43]. It was found that the normalized minimum creep rate - stress plot can be described by a single powerlaw relationship with the stress exponent, $\mathrm{n}=12$, i.e.:

$$
\frac{\dot{\varepsilon}}{D}=A^{\prime}\left(\frac{\sigma}{G}\right)^{12}
$$

where $A^{\prime}$ is the constant. Literature reported a stress exponent, $\mathrm{n} \sim 9$ for the power-law creep of Type $316 \mathrm{SS}$ at 600 and $650^{\circ} \mathrm{C}[35,41]$. It is noted that the stress dependence of the creep rate in AM 316L SS is stronger than that of conventionally-made 316 SS under similar creep conditions. As shown in Fig. 2-11, the microstructures of both AM 316L SS and solution-annealed wrought $316 \mathrm{H} \mathrm{SS}$ are dominated by a uniform dislocation structure after creep at $650^{\circ} \mathrm{C} 225 \mathrm{MPa}$. The dramatic difference in their initial dislocation structure has little influence on the end dislocation structure under creep. Kestenbach et al. [37] observed a strong correlation between dislocation structural changes and creep test conditions in 316 stainless steel. At low temperatures and high stresses, the microstructure of the creep specimen was dominated by a uniformly distributed dislocation structure or a duplex structure of dislocations and dislocation cells. There was a gradual transition from a grain-orientation dependent duplex substructure at high stresses to equiaxed subgrains at low stresses, and the transition is at $(\mathrm{d} \varepsilon / \mathrm{dt}) / \mathrm{D} \sim 10^{13} / \mathrm{m}^{2}$. It should be noted that all the creep tests conducted in this study are in the high stress region with (de/dt)/D $>10^{13} / \mathrm{m}^{2}$ (Fig. 2-12). The observed uniform dislocation structure or a duplex structure in AM 316L SS and 316H SS (shown in Fig. 2-11) are consistent with the findings in Type 316 SS reported in the literature.

Dislocation substructures are widely observed in conventionally-made 316 SS in creep tests at temperatures $>700^{\circ} \mathrm{C}$ [37-41]. A number of studies have reported an inverse relationship between the subgrain/cell size and the applied stress [38,46,47]. The subgrain/cell size, $\lambda$ varies with the applied stress, $\sigma$ following the relationship:

$$
\frac{\lambda}{b}=K\left(\frac{\sigma}{G}\right)^{-1}
$$

where $\mathrm{K}$ is a constant. We indeed observed that the residual dislocation cells in the creep tested specimens of AM 316L SS were refined, and the mean size of the cells was smaller under a higher creep stress. For example, a mean size of $382 \mathrm{~nm}$ was measured in the $650^{\circ} \mathrm{C} / 225 \mathrm{MPa}$ specimen, and $334 \mathrm{~nm}$ in the $550^{\circ} \mathrm{C} / 275 \mathrm{MPa}$ specimen. Though the measurements of residual dislocation cells in these two creep-deformed specimens were not as accurate as the one for the as-build 
specimen, these measurements provided important experimental evidence of the role of dislocation cells in the creep response of AM 316L SS. Literature reports a weak temperature dependence of the cell size in the temperature range of $550-650^{\circ} \mathrm{C}$ in $316 \mathrm{SS}$ [48].

For subgrain-strengthened materials, Sherby et al [45] showed that the creep rate is proportional to the cube of the subgrain size, $\lambda$, i.e.:

$$
\frac{\dot{\varepsilon}}{D}=A^{\prime \prime}\left(\frac{\lambda}{b}\right)^{3}\left(\frac{\sigma}{G}\right)^{n}
$$

where A" is the constant. Equation (2-2) can be re-written to include the dislocation cell effect in AM 316L SS, i.e.:

$$
\frac{\dot{\varepsilon}}{D}=A^{\prime \prime}\left(\frac{\lambda}{b}\right)^{3}\left(\frac{\sigma}{G}\right)^{12}
$$

Substituting Eq. (2-3) into Eq. (2-5) yields:

$$
\frac{\dot{\varepsilon}}{D} \propto\left(\frac{\sigma}{G}\right)^{9}
$$

Equation (2-6) describes the stress dependence of the creep rate of conventionally-made 316 SS, which shows the stress dependence of the creep rate with an exponent of 9 , consistent with the literature findings $[35,41]$. It is suggested that the stronger stress dependence of the creep rate in AM 316L SS is attributed to dislocation cell structure resulting from the printing process.

The controlling deformation mechanism in AM 316L SS does not seem to change in the temperature range of $550-650^{\circ} \mathrm{C}$, as shown in Fig. 2-12. The activation energy, $\mathrm{Q}$ for creep in this temperature range may be estimated by [44]:

$$
Q=\frac{R \ln \left(\frac{\varepsilon_{1}}{\varepsilon_{2}}\right)}{\left(\frac{1}{T_{2}}-\frac{1}{T_{1}}\right)}
$$

where $R$ is the gas constant $(8.31 \mathrm{~J} / \mathrm{mol} / \mathrm{K})$. The estimated activation energy for AM 316L SS was $430 \mathrm{~kJ} / \mathrm{mol}$, which is significantly higher than the activation energy for self-diffusion $(280 \mathrm{~kJ} / \mathrm{mol})$ for Type 316 SS [43]. Mazza and Willoughby [48] reported an activation energy of $565 \mathrm{~kJ} / \mathrm{mol}$ for Type $316 \mathrm{SS}$ at $600^{\circ} \mathrm{C}$. An activation energy of $500 \mathrm{~kJ} / \mathrm{mol}$ was found for $316 \mathrm{LN} \mathrm{SS}$ for creep at $625-700^{\circ} \mathrm{C}$ [49]. Sasikala et al [50] obtained an activation energy of $505 \mathrm{~kJ} / \mathrm{mol}$ for creep below $700^{\circ} \mathrm{C}$ for $316 \mathrm{SS}$. While there may be several factors that contribute to the high activation energy in AM 316L SS, the low carbon concentration in AM 316L SS can reduce the diffusivity and increase the activity energy [42].

The creep curves of AM 316L SS were dominated by accelerated creep. The minimum creep rates were achieved at a strain typically below $1 \%$. In contrast, well-annealed wrought 316 SS exhibited pronounced primary and secondary creep. Accelerated creep can result from either mechanical instability (e.g. necking) or microstructural instability (e.g. dynamic recovery, recrystallization, grain growth, microvoids). Since the accelerated creep occurred at a very early stage of creep $(<1 \%)$ in AM 316L SS, microstructural instability must be the main contributor to the accelerated creep. The dislocation cell structure formed during the printing process is not stable under creep, as shown in Fig. 2-11. It is widely accepted that the evolution of dislocation structure during creep depends on two processes: plastic deformation causes multiplication of dislocations and dislocations interact to form dislocation tangles; dynamic recovery leads to annihilation and 
rearrangements of dislocations. The dislocation cell structure in the as-built AM 316L SS limits its work hardening capacity. Upon the onset of creep deformation, there is a limited capacity of dislocation multiplication, and the minimum creep rate was achieved shortly. With the accumulation of creep deformation, emission of dislocations from cell walls can annihilate dislocations within cell walls, gradually eliminating cell boundaries. Eq. (2-4) indicates that refinement of subgrains/cells can reduce the creep rate. If the dislocation cell structure in the asbuilt AM 316L SS can be stabilized, e.g. by thermally-stable second-phase particles dispersed at cell boundaries, the creep resistance of AM 316L SS may be significantly improved. Oxide particles were observed at the boundaries in the as-built AM 316L SS (Fig. 2-7). The pinning effect of these particles appears to be limited during creep. Further investigation is needed to understand their role in stabilizing the cell structure in AM 316L SS. Another microstructural factor that could contribute to accelerated creep in AM 316L SS is internal porosity. Synchrotron X-ray tomography of the as-built AM 316L SS specimen measured $0.1 \%$ porosity of sizes of $>2 \mu \mathrm{m}$. Coalescence and growth of internal pores under creep could lead to accelerated creep at the early deformation stage.

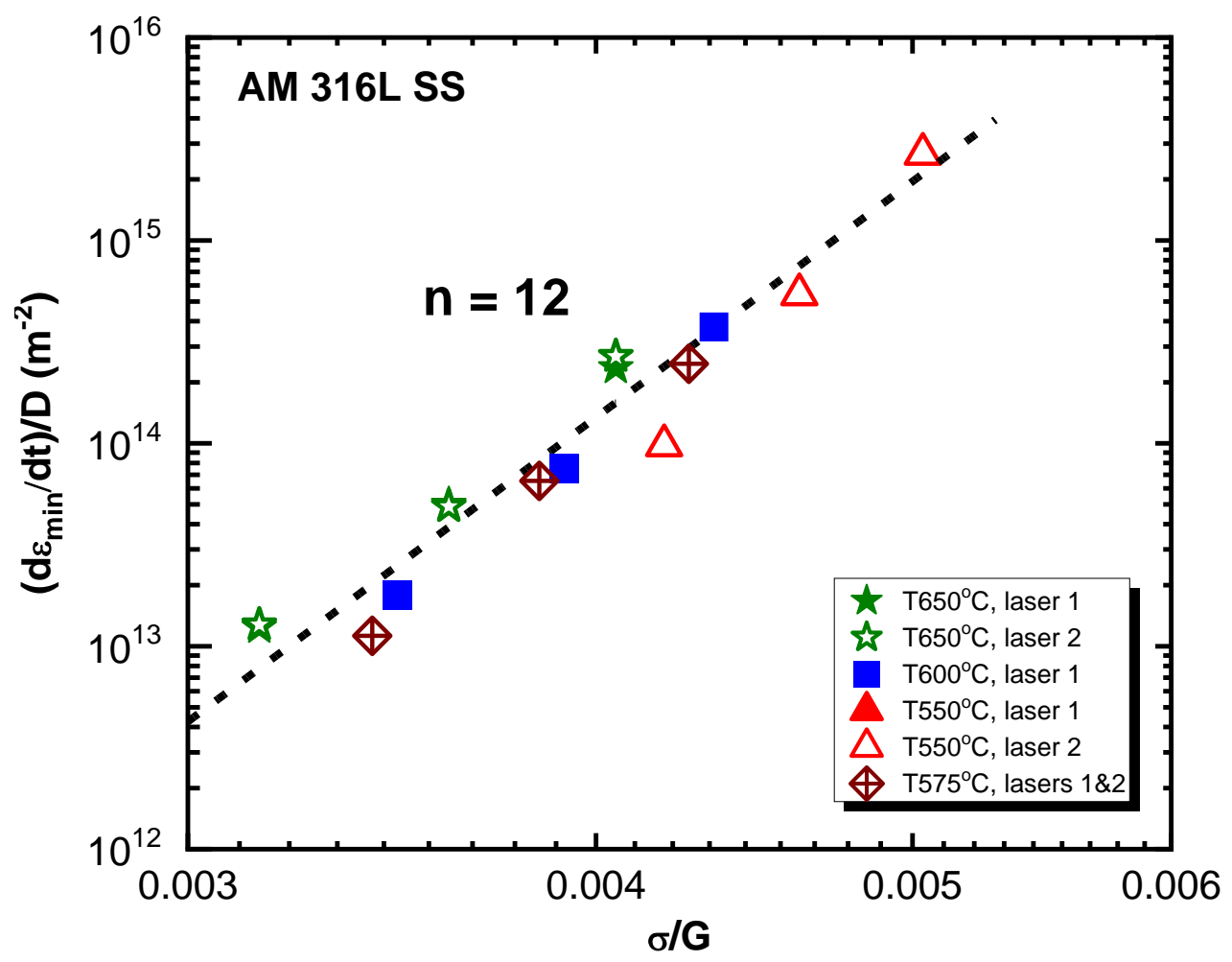

Figure 2-12. Normalized minimum creep rate, $\left(\mathrm{d} \varepsilon_{\min } / \mathrm{dt}\right) / \mathrm{D}$ vs. normalized stress, $\sigma / \mathrm{G}$ plot for AM 316L SS tested at 550, 575, 600, and $650^{\circ} \mathrm{C}$.

2.3.2. $\quad$ Creep Fracture Mechanism in AM 316L SS 
Intergranular creep fracture was observed in both AM 316L SS and wrought 316H SS (Fig. 2-10), which is consistent with the fracture mode observed in conventionally-made 316 SS [35,51]. Intergranular fracture at elevated temperatures is caused by the nucleation, growth and coalescence of grain boundary voids at low stresses or wedge-cracks at grain boundary junctions at high stresses, when grain boundary sliding cannot be accommodated elastically, by diffusion, or by plasticity or creep [52]. Metallic materials exhibiting intergranular creep fracture often follow the Monkman-Grant relationship [53]:

$$
t_{f} \dot{\varepsilon}_{S S}=C_{M G}
$$

where $\mathrm{t}_{\mathrm{f}}$ is the rupture life, and $\dot{\varepsilon}_{S S}$ is the steady-state or minimum creep rate, and $\mathrm{C}_{\mathrm{MG}}$ is called the Monkman-Grant constant. As shown in Figs. (2-6) and (2-12), the power-law creep controls the creep behavior of AM 316L SS. The creep rupture life of AM 316L SS may be estimated using the constrained cavity growth model. The model suggests that the kinetics of cavity growth at grain boundaries is controlled by coupled diffusion and power-law creep: voids grow by diffusion but at a rate limited by the power-law creep of the surrounding material. The time-to-fracture and the strain-to-fracture at a constant stress can be expressed as [52]:

$$
\begin{gathered}
\varepsilon_{s s}^{\cdot} t_{f} \geq \varepsilon_{s s}^{\cdot} t_{n}+\frac{1}{n} \ln \left[\frac{(1+P)^{n}}{(1+P)^{n}-\left(1-n f_{i}\right)}\right] \\
\varepsilon_{f} \geq \varepsilon_{n}+\frac{1}{n} \ln \left[\frac{(1+P)^{n}}{(1+P)^{n}-\left(1-n f_{i}\right)}\right]+\varepsilon_{t e r}
\end{gathered}
$$

where $\mathrm{t}_{\mathrm{n}}$ and $\varepsilon_{\mathrm{n}}$ are the time-to-void nucleation and the strain-to-void nucleation, respectively, $\mathrm{f}_{\mathrm{i}}$ is the initial area fraction of voids at boundaries, $\mathrm{P}$ a dimensionless quantity that determines the size of the diffusion zone, and $\varepsilon_{\text {ter }}$ the tertiary creep strain. Synchrotron X-ray tomography of the asbuilt AM 316L SS specimen showed $0.1 \%$ porosity of sizes of $>2 \mu \mathrm{m}$. It is reasonable to assume that internal porosity in AM 316L SS is the effective nuclei for creep cavities. In other words, the $\mathrm{t}_{\mathrm{n}}$ and $\varepsilon_{\mathrm{n}}$ in Eqs. (2-9) and (2-10) may be negligibly small and can be ignored for AM 316L SS. The creep life of AM 316L SS is consumed mostly by void growth. The left-hand value of Eq. (29) can be estimated using the minimum creep rate and the creep rupture life for AM 316L SS, which give a quantity of $0.03-0.11$. As shown in Fig. 2-13 where the creep elongation of AM 316L SS is plotted as a function of creep stress, the creep elongation of AM 316L SS is $>0.3$. It is apparent that a large fraction of the creep elongation of AM 316L SS was consumed in the final creep failure. In summary, it is suggested that the time-to-void nucleation is minimal in AM 316L SS because of the porosity resulted from printing, and the void growth life control the creep life of AM 316L SS; the creep ductility of AM 316L SS is dominated by the final creep failure.

Goods and Brown [54] pointed out that cavity nucleation at high temperatures is difficult. Cavities leading to creep fracture in engineering materials may be formed during processing, and a substantial increase in creep ductility may be achieved if the damage induced by processing or fabrication could be reduced. It was expected that the porosity resulting from the printing process in AM 316L SS would lead to low creep ductility relative to conventionally-made 316 SS (CM $316 \mathrm{SS}$ ). Figure 2-13 compares the creep elongations of AM $316 \mathrm{~L} \mathrm{SS}$ tested at $550-650^{\circ} \mathrm{C}$ in this study and the creep elongation data of CM 316 SS reported by Sasikala et al [35]. Surprisingly, AM 316L SS shows no inferior creep ductility compared to CM 316 SS. Several factors may be 
responsible for the good creep ductility of AM 316L SS: (1) the very low carbon content could significantly reduce the probability of precipitation of $\mathrm{M}_{23} \mathrm{C}_{6}$ carbides at grain boundaries, which can be the initiation sites of grain boundary voids [55]; (2) A high density of small porosity in AM 316L SS may serve as the initiation sites of creep cracks, resulting in highly-dispersed miniscule cracks at grain boundaries (Fig. 2-10(a)), impeding the formation of large grain boundary cracks observed in the 316H specimen (Fig. 2-10(b)). Bhuiyan and Fertig [56] have shown that the creep strain is linearly dependent on the microcrack density; (3) The transverse boundaries resulted from the layered structure in AM 316L SS (Fig. 9) can also suppress the formation of significant grain boundary cracks.

The creep cavity nucleation model developed by Fariborz et al [57] shows that the presence of nucleation can reduce the creep life by a factor of two to eight compared to the prediction without nucleation. The internal porosity in AM 316L SS may shorten the creep life due to the absence of the void nucleation stage but may provide a beneficial effect on the creep ductility by dispersing creep cracks.

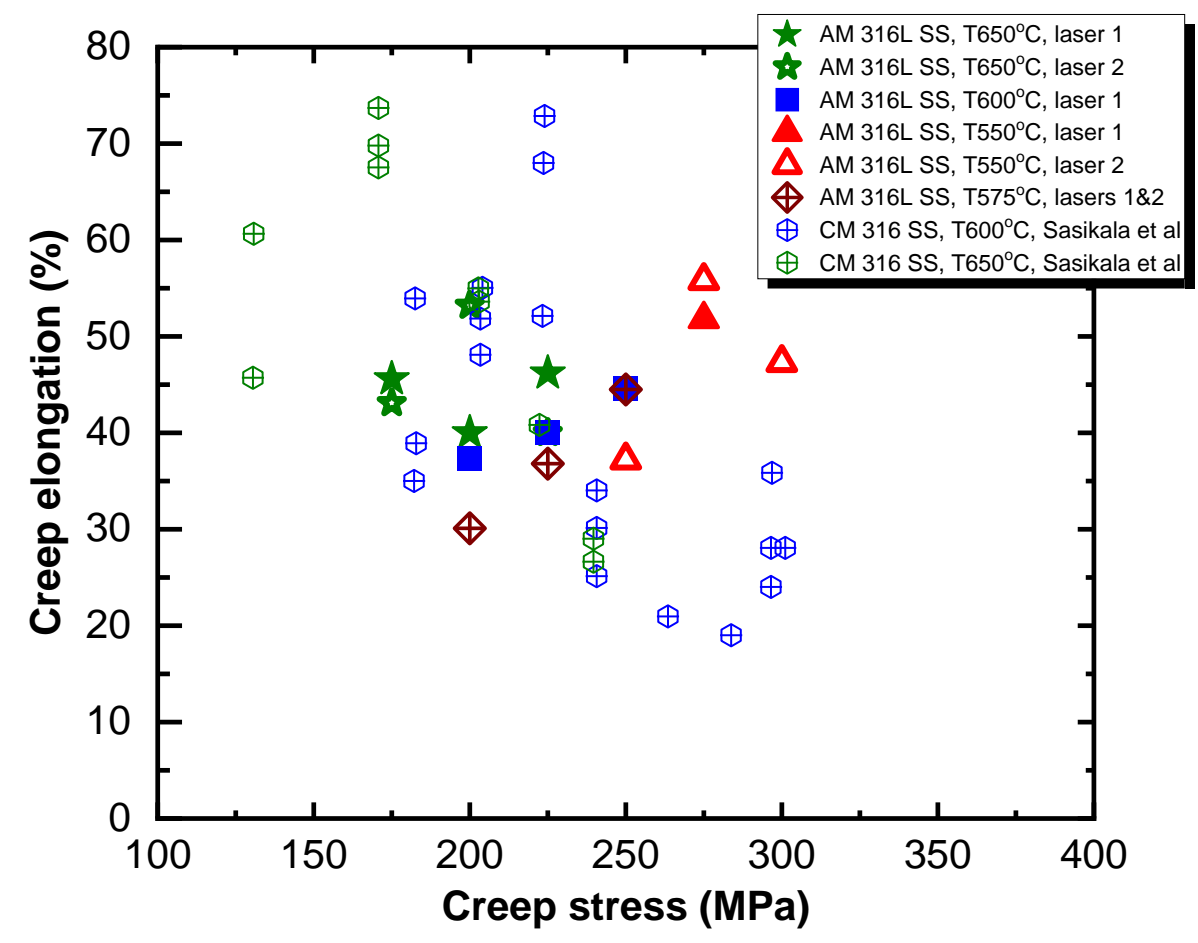

Figure 2-13. Comparison of creep elongations between AM 316L SS and conventionally-made 316 SS (CM 316 SS). 


\section{Effect of Heat Treatment on Creep Behavior of AM 316L SS}

\subsection{Experimental}

Post-build heat treatments were conducted on the rod specimens at 650, 700, 750, 800, 900 , and $1050^{\circ} \mathrm{C}$, respectively, for one hour. The annealing time was kept constant to investigate the effect of the heat treatment temperature. Each creep specimen was individually encapsulated in a quart tube under vacuum. Heat treatments were conducted on the encapsulated specimens in air furnaces. All the heat-treated specimens were creep tested under the same condition, namely, $550^{\circ} \mathrm{C}$ and $275 \mathrm{MPa}$. Table 3-1 lists the heat-treated rod specimens and creep testing conditions.

Microstructure of these specimens was examined after creep tests. Metallographic specimens were taken from the grip end or the gauge section near the fraction surface of the creeptested specimen and were examined by optical microscopy. Disk specimens were taken from the grip or gauge sections of creep-tested specimens in the transverse direction for TEM. Disk specimens of $3 \mathrm{~mm}$ in diameter were electropolished to perforation using an electrolyte of $95 \%$ methanol and $5 \%$ perchloric acid at $\sim-40^{\circ} \mathrm{C}$. Due to the presence of cracks and voids in the creep tested specimen, electropolished thin foil specimens were further ion milled to obtain appreciable thin areas for TEM examination. TEM and EDS were conducted on a FEI Talos F200X TEM at the Center for Nanoscale Materials (CNM), and a Hitachi H9000 at the IVEM-Tandem Facility, Argonne National Laboratory.

Table 3-1. List of heat treated rod specimens and creep testing conditions.

\begin{tabular}{|c|c|c|c|c|c|c|}
\hline $\begin{array}{c}\text { Specimen } \\
\text { ID }\end{array}$ & Build ID & Rod ID & $\begin{array}{c}\text { Laser } \\
\text { mode }\end{array}$ & Condition & $\begin{array}{c}\text { Test } \\
\text { Temp } \\
\left({ }^{\circ} \mathrm{C}\right)\end{array}$ & $\begin{array}{c}\text { Stress } \\
(\mathrm{MPa})\end{array}$ \\
\hline L106 & $20190308 \mathrm{M} 2$ & L1 & Laser 1 & $650^{\circ} \mathrm{C} / 1 \mathrm{~h}$ & 550 & 275 \\
\hline L206 & $20190308 \mathrm{M} 2$ & L2 & Laser 2 & $650^{\circ} \mathrm{C} / 1 \mathrm{~h}$ & 550 & 275 \\
\hline S-4 & $20190315 \mathrm{M} 2$ & S-4 & Laser $1 \& 2$ & $700^{\circ} \mathrm{C} / 1 \mathrm{~h}$ & 550 & 275 \\
\hline L2-3 & $20190315 \mathrm{M} 2$ & L2-3 & Laser 2 & $750^{\circ} \mathrm{C} / 1 \mathrm{~h}$ & 550 & 275 \\
\hline L2-4 & $20190315 \mathrm{M} 2$ & L2-4 & Laser 2 & $800^{\circ} \mathrm{C} / 1 \mathrm{~h}$ & 550 & 275 \\
\hline L1-4 & $20190315 \mathrm{M} 2$ & L1-4 & Laser 1 & $900^{\circ} \mathrm{C} / 1 \mathrm{~h}$ & 550 & 275 \\
\hline L205 & $20190308 \mathrm{M} 2$ & L2 & Laser 2 & $1050^{\circ} \mathrm{C} / 1 \mathrm{~h}$ & 550 & 275 \\
\hline
\end{tabular}




\subsection{Results}

\subsubsection{Creep Behavior of Heat-Treated Rod Specimens}

Creep curves of the heat-treated specimens tested at $550^{\circ} \mathrm{C}$ and $275 \mathrm{MPa}$ are shown in Figs. 3-1(a) and (b) where the creep strain is plotted as a function of time and the creep strain rate plotted as a function of creep strain, respectively. All the specimens exhibited predominantly accelerated creep. There was a strong effect of the heat treatment on the primary and secondary creep of the alloy, which can be seen in Fig. 3-1(c) where a magnified plot of Fig. 3-1(b) shows the primary and second creep of the creep rate - creep strain curves. The creep rate of the as-built specimen shows a short primary creep during which the creep rate continues to decrease with increasing strain and reaches a minimum; the creep rate then starts to increase continuously with increasing strain with almost no secondary creep. The creep rates of the $650^{\circ} \mathrm{C}$ - and $700^{\circ} \mathrm{C}$-heat treated specimens show similar behavior. As the heat treatment temperature increases above $700^{\circ} \mathrm{C}$, the specimens begin to show classical creep behavior with evident secondary creep where the creep rate remains a constant. When the heat treatment temperature increased to 900 and $1050^{\circ} \mathrm{C}$, AM 316L SS deviated from classical creep behavior again where the primary creep showed an increased creep rate, followed by secondary creep with a constant creep rate, and then an accelerated creep until failure. It was found that the strain to the onset of tertiary creep (SCTC) was $<1 \%$ in the as-built specimen and the specimens heat treated at 650 and $700^{\circ} \mathrm{C}$. The SCTC increased significantly when the heat treatment temperature was above $700^{\circ} \mathrm{C}$ and when secondary creep became increasingly more pronounced. The SCTC reached $9 \%$ in the $1050^{\circ} \mathrm{C}$ heat treated specimen.

A minimal effect of the heat treatment on tertiary creep was observed in AM 316L SS. As seen in Fig. 3-1(d) where the tertiary creep is presented in the magnified plot of Fig. 3-1(b), the as-built and the heat-treated specimens showed very similar behavior in the tertiary creep stage. In fact, when the creep rate curves are shifted in the y-axis by a different increment of creep rate, the portion of the tertiary creep of all the specimens can be described by a single curve, as seen in the insert of Fig. 3-1(d).

The creep rupture time, creep elongation, and minimum/secondary creep rate are plotted as a function of heat treatment temperature in Figs. 3-2(a), (b), and (c), respectively. The $650^{\circ} \mathrm{C}$ heat treated specimens have the longest creep lives among the as-built and heat-treated specimens. Above $650^{\circ} \mathrm{C}$ the creep life decreased continuously with increasing heat treatment temperature, and reaches the minimum at $900^{\circ} \mathrm{C}$. The $1050^{\circ} \mathrm{C}$ heat treatment slightly restored the creep life of AM 316L SS. On the other hand, the creep elongation was the lowest after the heat treatment at $650^{\circ} \mathrm{C}$ and reached the maximum after the heat treatment temperature at $900^{\circ} \mathrm{C}$, showing the opposite trend to the creep rupture life. The minimum/secondary creep rate reached the minimum after the heat treatment at $650^{\circ} \mathrm{C}$ and the maximum at $900^{\circ} \mathrm{C}$, also showing the opposite trend to the creep rupture life. 


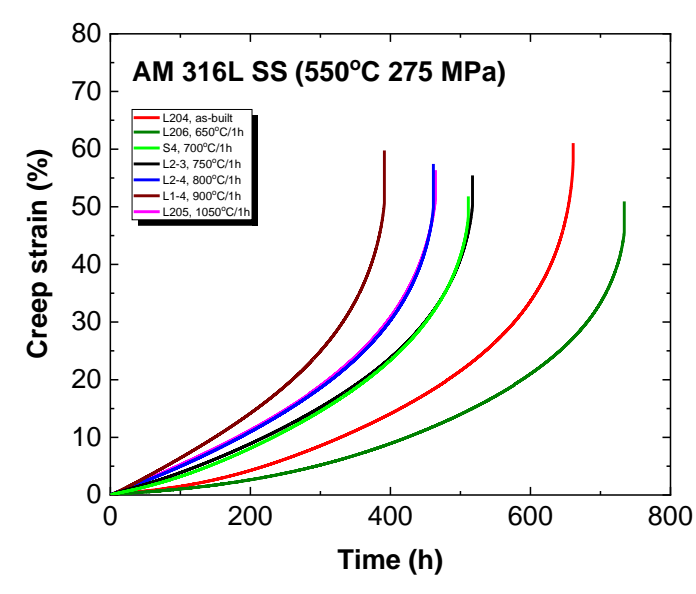

(a)

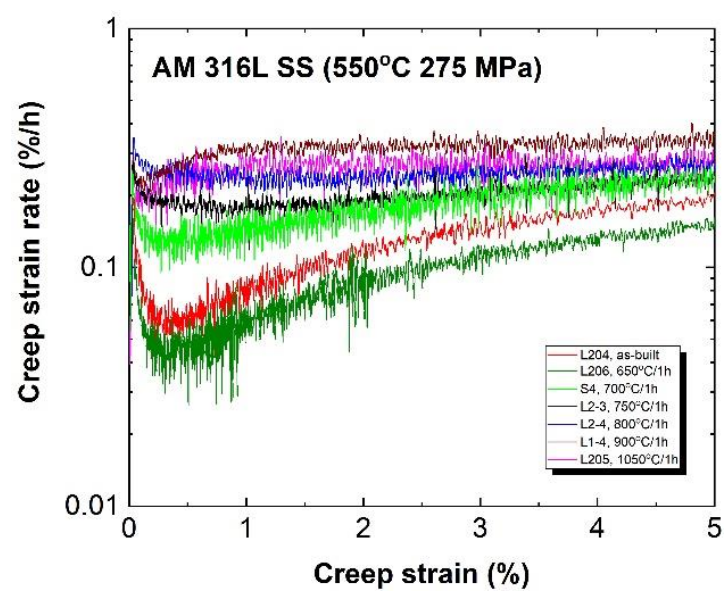

(c)

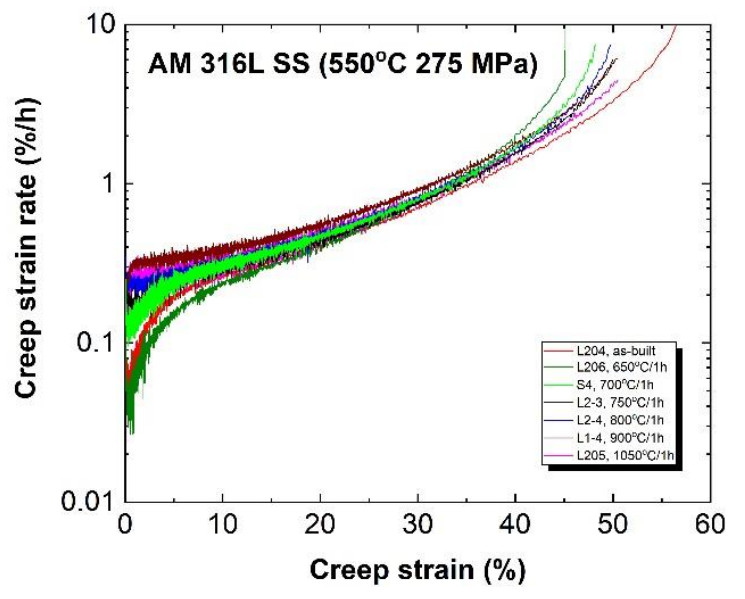

(b)

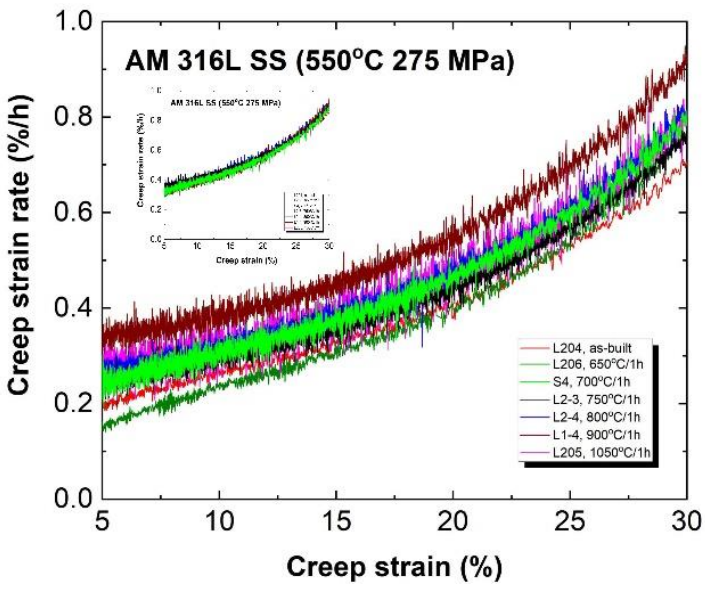

(d)

Figure 3-1. Creep curves of AM 316L SS heat treated at different temperatures (a) creep strain vs. time, (b) creep strain rate vs. creep strain, (c) a magnified plot of (b) showing the primary and secondary creep, and (d) a magnified plot of (b) showing the tertiary creep (inset showing curves shifted in the y-axis).

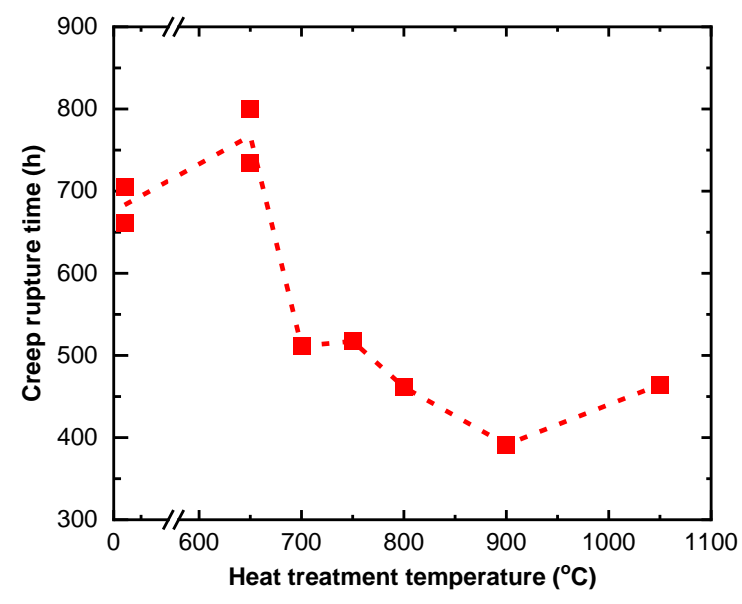

(a) 


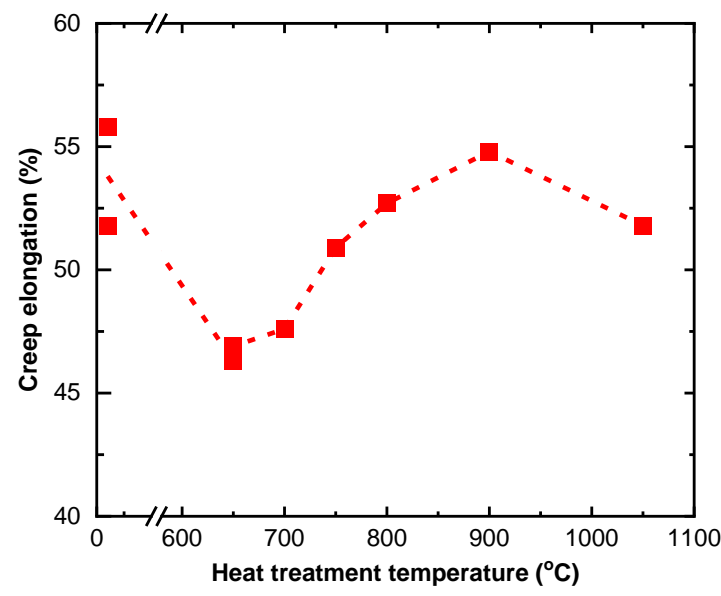

(b)

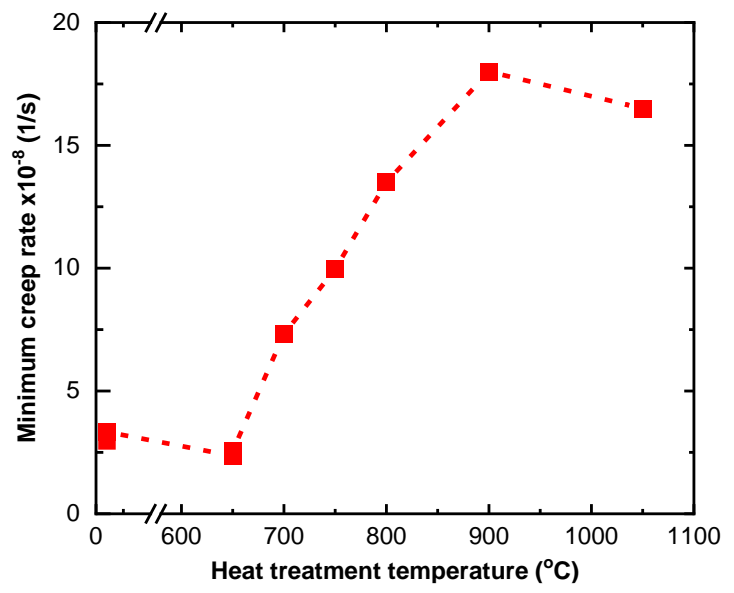

(c)

Figure 3-2. Effect of heat treatments on (a) the creep rupture life, (b) the creep elongation, and (c) minimum/secondary creep rate of AM $316 \mathrm{~L} \mathrm{SS}$ tested at $550^{\circ} \mathrm{C}$ and $275 \mathrm{MPa}$.

\subsection{2. $\quad$ Microstructure of Heat-treated Rod Specimens}

Figure 3-3 shows the optical images of the microstructure of AM 316L SS in the as-built condition or after heat treatments at various temperatures. Microstructure of these specimens was examined after creep tests at $550^{\circ} \mathrm{C}$ and $275 \mathrm{MPa}$. It should be noted that these specimens experienced an additional thermal exposure at $550^{\circ} \mathrm{C}$ during creep, and the thermal exposure temperature and time for each specimen are given in the paratheses in Fig. 3-3. Previous studies have shown that the microstructure of AM $316 \mathrm{~L} \mathrm{SS}$ is stable below $600^{\circ} \mathrm{C}$ [19-28].

The as-built specimen shows a layered structure separated by melt pool boundaries. Within the melt pool, columnar grains grow in the build direction. The grain size in the cross section was 20-30 $\mu \mathrm{m}$. Defects, e.g. lack of fusion, gas pores, were evident. After heat treatments at 650 and $750^{\circ} \mathrm{C}$ melt pool boundaries were still visible though they were much thinner. They were nearly invisible after heat treatments at temperatures above $750^{\circ} \mathrm{C}$. Ronneberg et al [23] pointed out that melt pool boundaries are thin bands with slightly different composition from the melt pool interior. 
The gradual removal of melt pool boundaries by heat treatment indicated an increasing influence of atomic diffusion at high temperature which homogenizes the melt pool composition.

The heat treatment at $1050^{\circ} \mathrm{C}$ further homogenizes the microstructure of AM 316L SS. The initial columnar grains started to lose their shapes, implying the occurrence of recrystallization. Voisin et al [22] found that the overall grain structures of AM 316L SS remained stable up to 800$1000^{\circ} \mathrm{C}$ and near defect-free grains formed at $\geq 1100^{\circ} \mathrm{C}$. Deng et al [20] reported full recrystallization of $\mathrm{AM} 316 \mathrm{~L} \mathrm{SS}$ after annealing at $1065^{\circ} \mathrm{C}$ and $1150^{\circ} \mathrm{C}$. Our results are consistent with these findings. It should be mentioned that that no evident effects of heat treatments on porosity were observed in AM 316L SS.
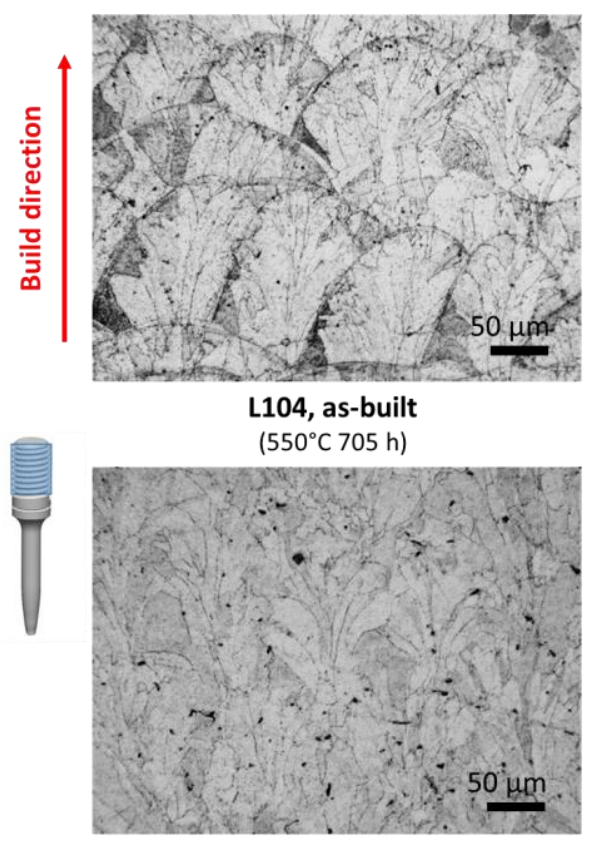

L2-4, HT $800^{\circ} \mathrm{C} / 1 \mathrm{~h}$

$\left(550^{\circ} \mathrm{C} 461 \mathrm{~h}\right)$

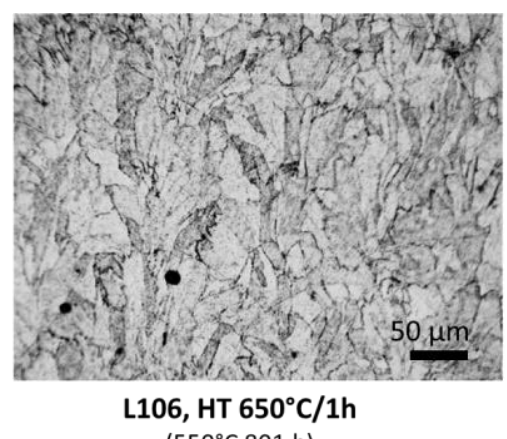

$\left(550^{\circ} \mathrm{C} 801 \mathrm{~h}\right)$

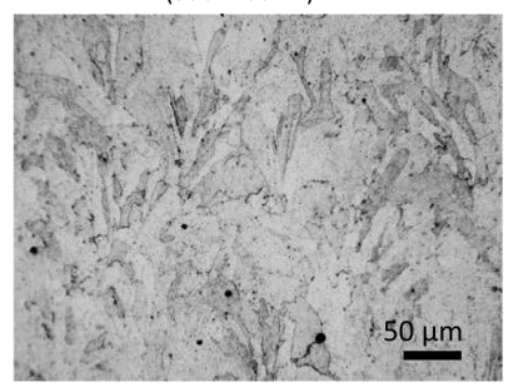

L1-4, HT $900^{\circ} \mathrm{C} / 1 \mathrm{~h}$

$\left(550^{\circ} \mathrm{C} 391 \mathrm{~h}\right)$

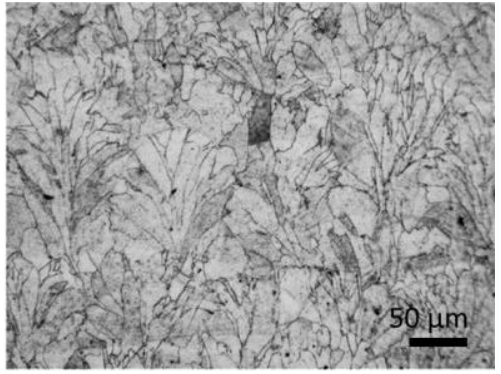

L2-3, HT $750^{\circ} \mathrm{C} / 1 \mathrm{~h}$

$\left(550^{\circ} \mathrm{C} 517 \mathrm{~h}\right)$

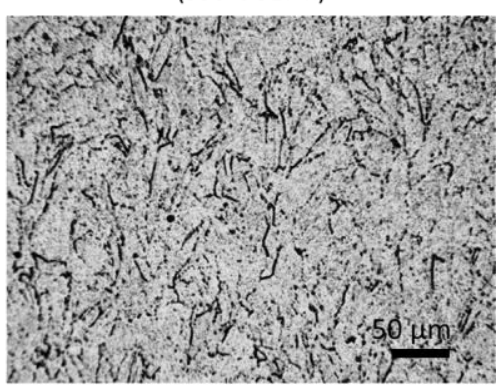

L205, HT $1050^{\circ} \mathrm{C} / 1 \mathrm{~h}$

$\left(550^{\circ} \mathrm{C} 464 \mathrm{~h}\right)$

Fig. 3-3. Optical images showing the microstructure of heat-treated AM 316L SS in the build direction. Metallographic specimen was taken from the grip section of the creep-tested specimen.

Thermal exposure condition during creep is given in the parathesis for each specimen.

The microstructure of the heat-treated specimens was also examined by TEM. Figure 3-4 shows TEM bright-field images of the specimens in the as-built condition or after heat treatment at $650,750,800,900$ and $1050^{\circ} \mathrm{C}$, respectively. The high-magnification images in Fig. 3-4 reveal the details of dislocation substructures while the low-magnification images give an overview of the substructures. Dislocation substructures were observed in all the specimens and there were minimal misorientation differences between substructures in these specimens. "Dislocation cells" and "subgrains" are traditionally used to describe the morphologies of dislocation substructures. Dislocation cells often refer to dislocation substructures consisting of broad, diffused boundaries containing dislocation tangles, while subgrains refer to substructures with narrow and well-defined sub-boundaries. Sometimes these two terms are used interchangeably. 
The as-built AM 316L SS showed dislocation cells resulting from the printing process. Cell walls consisted of dislocation tangles and cell interior had a low density of dislocations. The mean cell size in the as-built specimen was $530 \pm 62 \mathrm{~nm}$ and the cell wall thickness was $96 \mathrm{~nm}$. Here the cell size is defined as the shortest width of a cell, and it was obtained by measuring the distance between the middle-lines of the cell walls. After the heat treatment at $650^{\circ} \mathrm{C}$, the mean cell size was reduced to $393 \pm 33 \mathrm{~nm}$ while the cell wall thickness increased to $\sim 110 \mathrm{~nm}$. When the heat treatment temperature increased to $750^{\circ} \mathrm{C}$, the density of tangled dislocations within cell walls was significantly reduced and the cell walls became much thinner. The mean cell size and cell wall thickness were $337 \pm 19 \mathrm{~nm}$ and $47 \mathrm{~nm}$, respectively in the $750^{\circ} \mathrm{C}$-heat treated specimen. As the heat treatment increased to $800^{\circ} \mathrm{C}$, cells coarsened and the mean cell size increased to $526 \pm 36 \mathrm{~nm}$. Cell walls became narrower and the overall dislocation density was lower. In the $900^{\circ} \mathrm{C}$-heat treated specimen tangled dislocations in cell walls were replaced by regular dislocation arrays, forming sub-boundaries and few dislocations were observed within subgrains. The mean subgrain sizes in the $900^{\circ} \mathrm{C}$-heat treated specimens was $508 \pm 37 \mathrm{~nm}$, similar to that of the $800^{\circ} \mathrm{C}$-heat treated specimen. Unlike the heat treatments at lower temperatures, the $1050^{\circ} \mathrm{C}$ heat treatment removed cell structures in the as-built specimen. Dislocations remained inside the grains, pinned by secondphase particles. Table 3-2 summarizes the measurements of cell/subgrain size and boundary thickness. Deng et al [20] reported that the cellular structure in AM 316L SS remained stable at $600^{\circ} \mathrm{C}$ but coarsened slightly after annealing at $700^{\circ} \mathrm{C}$. The coarsening of cell structures was accompanied by a decrease in hardness in AM 316L SS. Voisin et al [22] found that dislocations in cell walls started to disentangle at $800^{\circ} \mathrm{C}$ and cells disappeared at $1000^{\circ} \mathrm{C}$. At $1200^{\circ} \mathrm{C}$ the microstructure fully transformed into equiaxed, near defect-free grains. Our experiments confirmed previous findings.

Figure 3-5 shows high-angle annular dark-field (HAADF) images and EDS elemental maps. In the as-built specimens, particles were found mostly at cell boundaries. These particles were oxides enriched in $\mathrm{Si}, \mathrm{Mn}$. The mean size of oxide particles was $25 \pm 9 \mathrm{~nm}$. Elemental segregation was observed at cell boundaries which were enriched in $\mathrm{Cr}$ and Mo and depleted of $\mathrm{Fe}$. Minimal changes occurred to the oxide particles and boundary segregation after heat treatments at 650 and $750^{\circ} \mathrm{C}$. However, when the heat treatment temperature increased to $800^{\circ} \mathrm{C}$, oxide particles coarsened, Mo-rich precipitates formed, and boundary elemental segregation became less evident. As the heat treatment temperature increased to $900^{\circ} \mathrm{C}$, no boundary elemental segregation was detected and oxide particles nearly dissolved. After the heat treatment at $1050^{\circ} \mathrm{C}$, new oxide particles formed and they were enriched in $\mathrm{Cr}$ and $\mathrm{Mn}$, which have different chemistry from oxide particles observed in the as-built specimen. The particle mean sizes were $87 \mathrm{~nm}$ in the $1050^{\circ} \mathrm{C}$ heat treated specimens, significantly larger than those in the as-built specimen. These findings are generally consistent with the results reported in the literature [15,22]. However, Kong et al [25] found that the $(\mathrm{Mn}, \mathrm{Si})$ nano-particles in the as-built $\mathrm{AM} 316 \mathrm{~L}$ became smaller and the content of $\mathrm{Si}$ and $\mathrm{Mn}$ became lower after heat treatment at $1050^{\circ} \mathrm{C}$ for $30 \mathrm{~min}$. The differences in particle evolution could be affected by the variations in the initial microstructure and chemistry resulting from the printing process. 

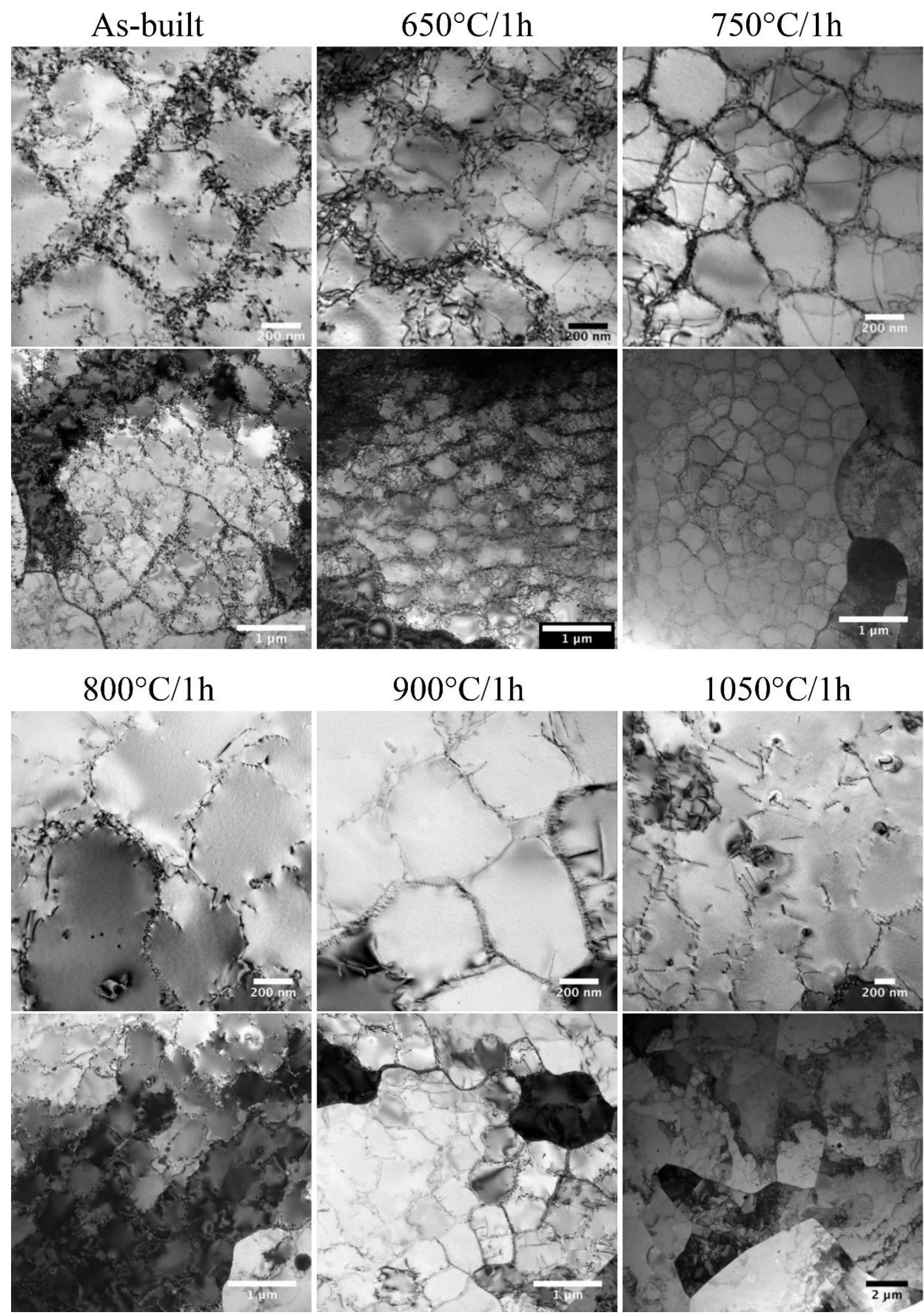

Figure 3-4. TEM micrographs showing the microstructure of the AM 316L SS specimens in the as-built condition or after heat treatments at $650,750,800$, and $900^{\circ}$, and $1050 \mathrm{C}$, respectively. 
Table 3-2. Cell/subgrain size and boundary thickness

\begin{tabular}{|c|c|c|c|c|c|c|}
\hline Condition & As-built & $650^{\circ} \mathrm{C}$ & $750^{\circ} \mathrm{C}$ & $800^{\circ} \mathrm{C}$ & $900^{\circ} \mathrm{C}$ & $1050^{\circ} \mathrm{C}$ \\
\hline $\begin{array}{c}\text { Mean cell/subgrain } \\
\text { size (nm) }\end{array}$ & $530 \pm 62$ & $393 \pm 33$ & $337 \pm 19$ & $526 \pm 36$ & $508 \pm 37$ & - \\
\hline $\begin{array}{c}\text { Mean boundary } \\
\text { thickness (nm) }\end{array}$ & 96 & 110 & 47 & - & - & - \\
\hline
\end{tabular}
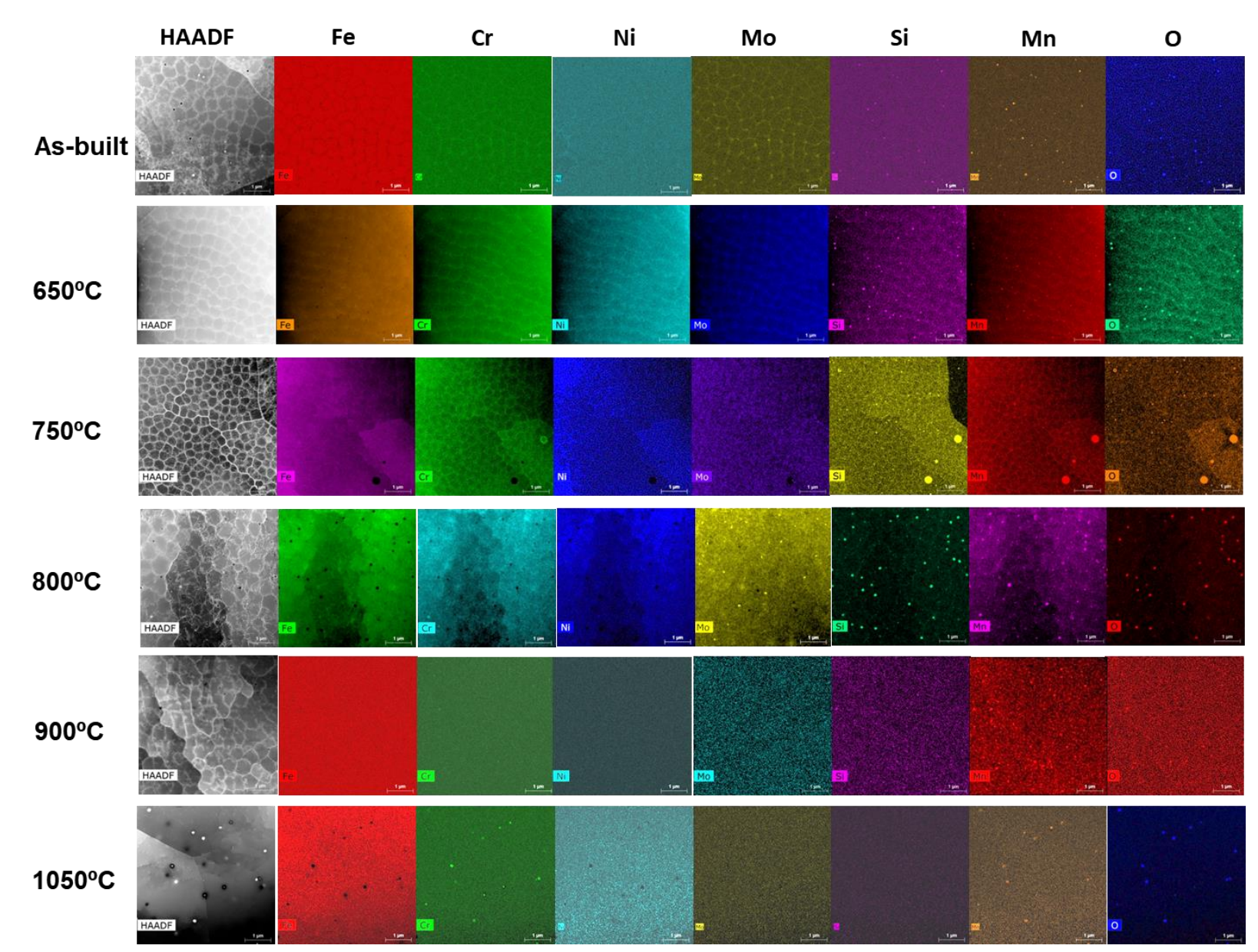

Figure 3-5. HAADF micrographs and EDS elemental maps of the AM 316L SS specimens in the as-built condition or after heat treatments at $650,750,800$, and $900^{\circ}$, and $1050 \mathrm{C}$, respectively. 


\subsubsection{Microstructure of Heat Treated Rod Specimens after Creep}

Creep damage of the heat-treated specimens was characterized by optical microscopy after creep. Metallographic specimens were taken in the gauge section in the longitudinal direction. Figure 3-6 shows optical micrographs of the specimens heat treated at different temperatures and in the as-built condition after creep. Grain boundary cracking was the dominant failure mode in all the specimens. Cracks grew primarily along the grain boundaries perpendicular to the loading direction. Grains were severely distorted under creep deformation. The gauge sections of these specimens were also characterized by synchrotron X-ray tomography at the Advanced Photon Source, and the data is being analyzed.

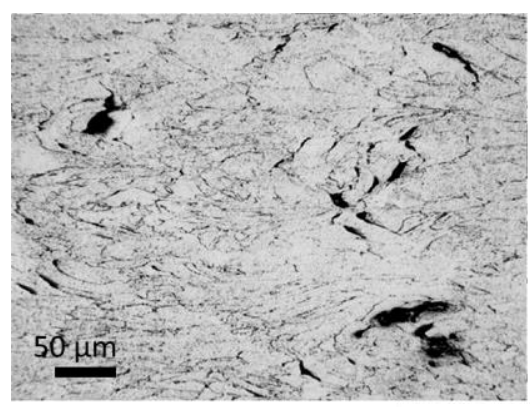

L104, as-built

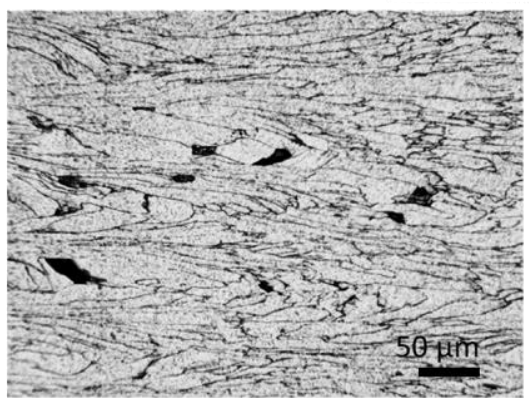

$\mathrm{L} 2-4, \mathrm{HT} 800^{\circ} \mathrm{C} / 1 \mathrm{hr}$

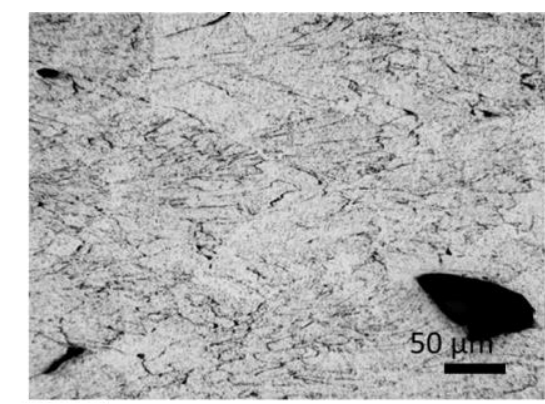

L106, $\mathrm{HT} 650^{\circ} \mathrm{C} / 1 \mathrm{hr}$

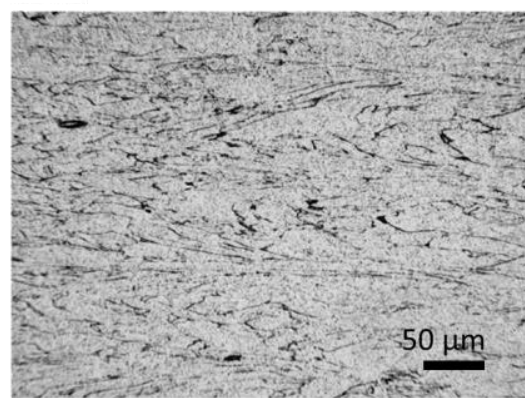

L1-4, HT $900^{\circ} \mathrm{C} / 1 \mathrm{hr}$

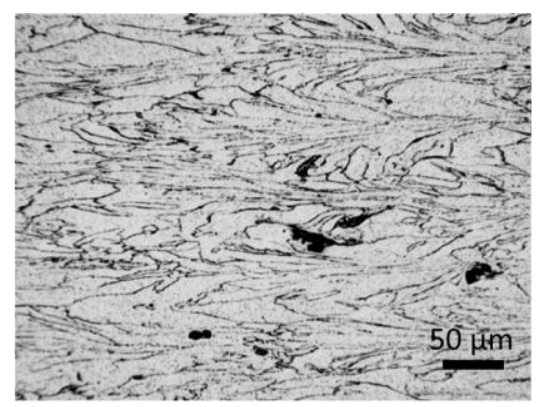

$\mathrm{L} 2-3, \mathrm{HT} 750^{\circ} \mathrm{C} / 1 \mathrm{hr}$

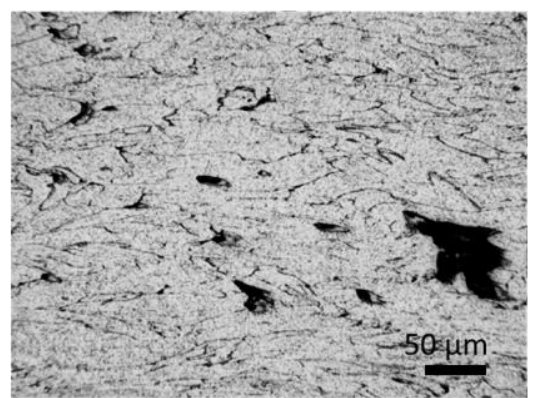

L205, HT $1050^{\circ} \mathrm{C} / 1 \mathrm{hr}$

Figure 3-6. Optical micrographs of the gauge sections of the creep tested $\left(550^{\circ} \mathrm{C} / 275 \mathrm{MPa}\right)$ specimens in the as-built condition or heat treated at different temperatures.

Microstructure of the gauge sections of the creep-tested specimens was also examined by TEM. Figure 3-7 shows TEM images of the as-built, $650^{\circ} \mathrm{C}$-heat treated, and $1050^{\circ} \mathrm{C}$-heat treated AM $316 \mathrm{~L}$ SS specimens after creep tests at $550^{\circ} \mathrm{C} / 275 \mathrm{MPa}$. It was found that the initial dislocation cell structure in the as-built and $650^{\circ} \mathrm{C}$-heat treated specimens disappeared after creep and evolved into a uniformly-distributed high-density dislocation structure. The $1050^{\circ} \mathrm{C}$-heat treated specimen showed a similar dislocation structure with uniformly-distributed high-density dislocations, though its initial microstructure before creep had no dislocation cells, unlike the asbuilt and $650^{\circ} \mathrm{C}$-heat treated specimens. It appeared that the dislocation structure after creep was not sensitive to the initial microstructure of the specimen before creep. Rather it depends mainly on the creep testing condition. Similar findings on wrought 316 SS have been reported in the literature [58]. 


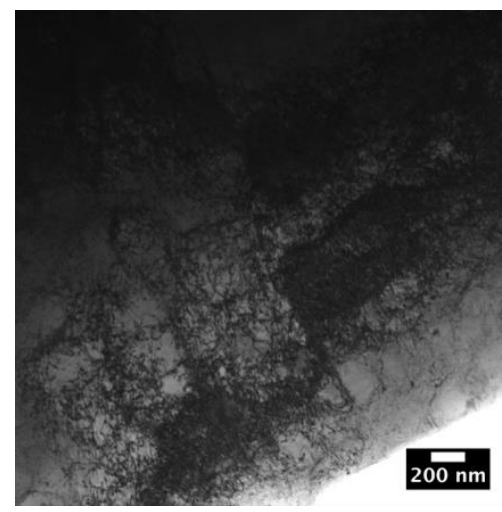

(a)

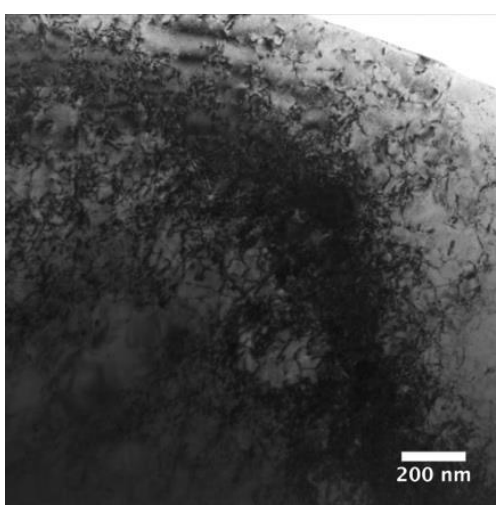

(b)

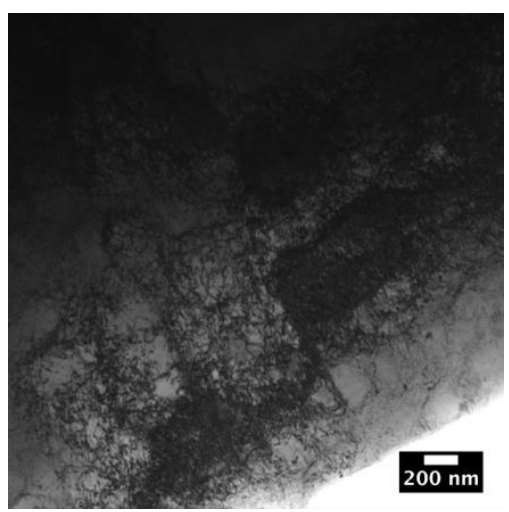

(c)

Figure 3-7. TEM micrographs showing the microstructure after creep test at $550^{\circ} \mathrm{C} / 275 \mathrm{MPa}$ for AM316L SS (a) as-built, (b) heat-treated at $650^{\circ} \mathrm{C} / 1 \mathrm{~h}$, and (c) heat treated at $1050^{\circ} \mathrm{C} / 1 \mathrm{~h}$.

\subsection{Discussion}

\subsubsection{Effect of Post-Build Heat Treatment on Creep Behavior of AM 316L SS}

The post-build heat treatment has a strong effect on the creep properties of AM 316L SS, as shown in the previous section. The creep rupture life increased after the heat treatment at $650^{\circ} \mathrm{C}$, and then decreased with increasing heat treatment temperatures up to $900^{\circ} \mathrm{C}$ when cell/subgrain structures still existed. The creep rate and creep ductility followed the opposite trend. The effect of heat treatment was different in different stages of creep. The primary and second creep of AM 316L SS was strongly affected by the heat treatment. The shapes of the creep curves in the primary and second creep were sensitive to the heat treatment, as shown in Fig. 31. Ancker et al [58] reported that the shape of the creep curve was a function of the initial quantity of small-angle dislocation boundaries. The difference in the creep response of AM 316L SS in primary and second creep may be largely associated with the changes of cells/subgrains during the heat treatment.

On the contrary, the tertiary creep of AM 316L SS was insensitive to the heat treatment. The portion of the tertiary creep of all the specimens can be described by a single curve after shifting in the y-axis, as shown in Fig. 3-1(d). The effect of heat treatments on tertiary creep can be further understood by comparing the creep ductility and the strain to the onset of tertiary creep (SOTC). Figure 3-8 plots the creep elongation and the SOTC as a function of heat treatment temperature for AM 316L SS tested at $550^{\circ} \mathrm{C}$ and $275 \mathrm{MPa}$. It is noted that both the creep elongation and the SOTC increase with increasing heat treatment temperature up to $900^{\circ} \mathrm{C}$. However, the difference between the creep elongation and the SOTC is less dependent on the heat treatment temperature (shown in the shaded area of Fig. 3-8). It implies that the tertiary creep strain is not heavily affected by the heat treatment, and the change in creep ductility after the heat treatment is mainly a result of the changes in primary and secondary creep strains. In other words, 
the heat treatment delays the onset of tertiary creep, except the $1050^{\circ} \mathrm{C}$-heat treated specimen where dislocation cell structures are completely destroyed. It is suggested that the shorter creep lives after heat treatments at higher temperatures is a consequence of the higher creep rates developed in the primary and secondary creep.

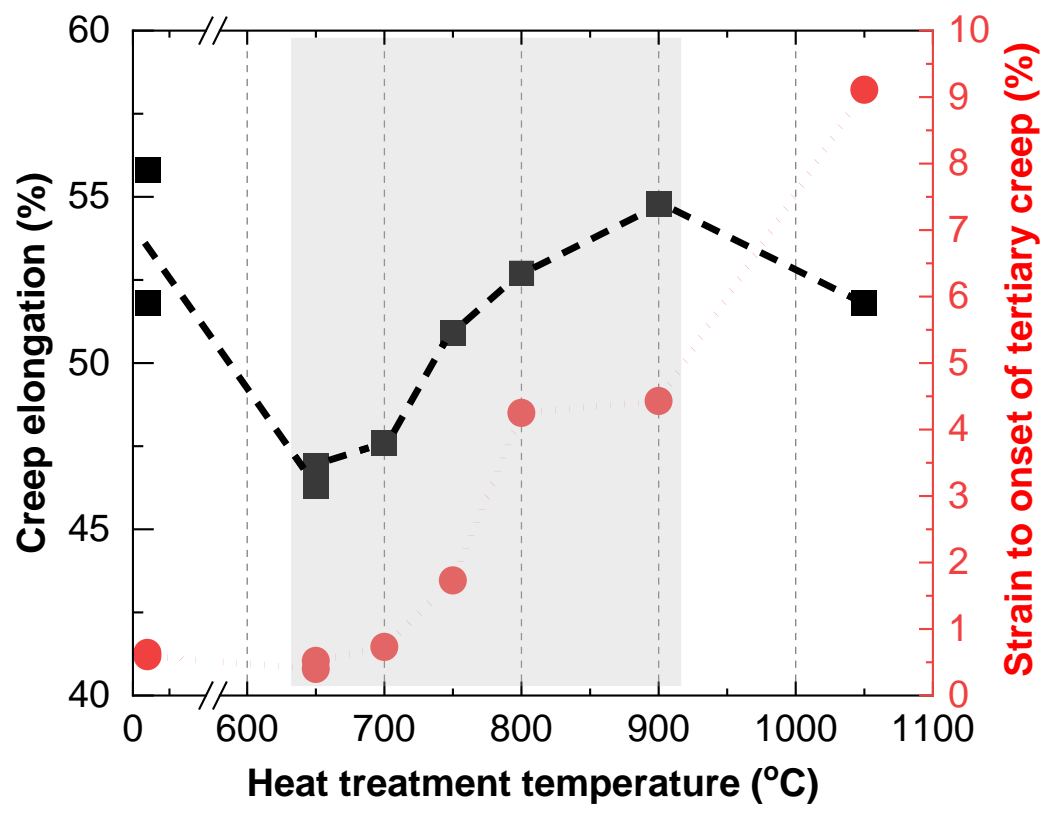

Figure 3-8. The creep elongation and the strain to the onset of tertiary creep as a function of heat treatment temperature for AM $316 \mathrm{~L} \mathrm{SS}$ tested at $550^{\circ} \mathrm{C}$ and $275 \mathrm{MPa}$.

\subsubsection{Effect of Post-Build Heat Treatment on Microstructure of AM 316L SS}

The LPBF process produces a highly non-equilibrium, heterogenous microstructure in AM 316L SS. The as-built specimen has a hierarchical structure consisting of columnar grains within melt pool boundaries, dislocation cell structures within grains, a low density of dislocations within cells, solute segregation at boundaries, and oxide particles. This highly non-equilibrium microstructure has an excessively high energy, and post-build heat treatments can relieve the free energy through recovery, homogenization, and recrystallization [20]. We have shown that microstructure of AM 316 SS was progressively transformed with increasing heat treatment temperature. Because of a number of characteristic phenomena observed in the range of the heat treatment temperature, it is convenient to divide the discussion on microstructural evolution into various temperature regimes:

- $650-750^{\circ} \mathrm{C}$

In this temperature range the characteristic changes were dislocation density within cells, and cell size and wall thickness. Elemental segregation at boundaries (including both melt pool boundaries and cell boundaries) remained unchanged and Mn-enriched Si oxide particles remained stable. 
The heat treatment at $650^{\circ} \mathrm{C}$ reduced the mean cell size. Fewer dislocations were observed inside the cells after the heat treatment. Dislocations within the cell walls straightened. It is apparent that dislocation structures formed during printing continued to evolve to reduce the total elastic energy of dislocations. Birnbaum et al [59] suggested that dislocation cell structures in AM 316L SS are formed due to the residual stress developed during solidification. Local stresses and strains developed from thermal shrinkage can drive local quenched-in dislocations to continue to evolve into low-energy cell boundaries to relieve local stored energy, resulting in smaller dislocation cells during $650^{\circ} \mathrm{C}$ annealing. Holt [60] pointed out that the dislocation cell size, $\lambda$ is inversely proportional to the square root of the dislocation density, $\rho$, i.e.,

$$
\lambda=\mathrm{K} \rho^{-0.5}
$$

where $\mathrm{K}$ is a constant. Holt suggested that a uniformly dense dislocation structure was unstable and tended to cluster to form cell structures to reduce the elastic energy of dislocations by analogy with spinodal decomposition. The cell size - dislocation density relationship was observed in wrought 316 SS [46]. This relationship was recently verified by a thermodynamic analysis on the formation energy of dislocation cells [61] and is applicable within a certain temperature regime where dislocation mobility is high enough to allow forming a low-energy dislocation configuration but low enough to limit considerable dislocation annihilation to form low-energy boundaries [62].

As the heat treatment temperature increases, dislocation mobility increases and dislocation annihilation becomes more prominent. Dislocation tangles within cell walls increasingly merge and cell boundaries sharpen. As observed in the $750^{\circ} \mathrm{C}$-heat treated specimen, the width of the cell wall was reduced by $>50 \%$ compared to the $650^{\circ} \mathrm{C}$-heat treated specimen, while the change in the mean size of dislocation cells was less significant.

\section{- $750-900^{\circ} \mathrm{C}$}

In this temperature range, concurrent changes were observed in dislocation cell structures, elemental segregation and oxide particles. The enrichment of $\mathrm{Cr}$ and $\mathrm{Mo}$ at cell boundaries in the as-built specimen has a trapping effect on dislocations and can stabilize cell boundaries [20, 22]. At high temperature the diffusivities of $\mathrm{Cr}$ and Mo increase. The $\mathrm{Cr}$ and Mo atoms start to diffuse away from cell boundaries. While segregation of $\mathrm{Cr}$ and $\mathrm{Mo}$ was still detectable after the $800^{\circ} \mathrm{C}$ heat treatment, boundary elemental segregation was not observed after the heat treatment at $900^{\circ} \mathrm{C}$. Melt pool boundaries which have slightly different composition from the interior, also gradually disappeared with increasing heat treatment temperatures. Voisin et al [22] studied $\mathrm{Cr}$ and Mo elemental diffusion in AM 316L SS under annealing by CALPHAD simulation. They showed that diffusion of $\mathrm{Cr}$ and Mo across the cell wall started at $650^{\circ} \mathrm{C}$, and both elements were fully homogenized with matrix below $900^{\circ} \mathrm{C}$ when the annealing time was held between 15 min to $2 \mathrm{~h}$. Our experimental results are consistent with their CALPHAD simulation results.

The Mn-enriched Si oxide particles in the as-built specimen started to transform in this temperature range as well. They gradually dissolved and were replaced by new particles of $\mathrm{Mn}$ enriched $\mathrm{Cr}$ oxides at high heat treatment temperature. Chen et al [21] observed the dissolution of silicates after annealing at $800^{\circ} \mathrm{C}$ for one hour in AM 316L SS and found that both the volume fraction and the size of silicates were reduced. Yan et al [63] reported that the nanoscale Mnenriched silicon oxides in LPBF 316L SS are $\mathrm{MnSiO}_{3}$ Rhodonite. $\mathrm{MnSiO}_{3}$ Rhodonite particles were replaced by $\mathrm{MnCr}_{2} \mathrm{O}_{4}$ Spinel particles after annealing at $1200^{\circ} \mathrm{C}$ for $1 \mathrm{~h}$ or longer. The phase 
transition from Rhodonite to Spinel was explained by the metastable phase diagram of 316L SS calculated by the Thermo-Calc software. A lower interfacial energy of the metastable Rhodonite phase promoted its formation during rapid solidification of the printing process. During post-build annealing, $\mathrm{Cr}$ atoms diffuse to $\mathrm{MnSiO}_{3}$ Rhodonite particles and form thermodynamically stable $\mathrm{MnCr}_{2} \mathrm{O}_{4}$ Spinel particles.

Removal of solute segregations at cell boundaries increases dislocation mobility within cell walls. High temperature also increases dislocation mobility. Sufficient three-dimensional dislocation mobility (e.g. climb) is needed for dislocation reorganization or annihilation, forming sharper low-energy boundaries. Dislocation cells coarsened during the heat treatment at $800^{\circ} \mathrm{C}$. The mean cell size increased to $526 \pm 36 \mathrm{~nm}$ and cell boundaries became thinner. Further increase in heat treatment temperature to $900^{\circ} \mathrm{C}$ caused no significant change in cell size but resulted in formation of well-organized subgrains. Similar development of dislocation cells and subgrains were observed in tensile deformed regular 316 SS [46]. A concurrent increase in the regularity of cell walls and cell size was observed in tensile-deformed 316SS at temperatures near $0.5 \mathrm{~T}_{\mathrm{m}}$, and a rapid increase in subgrain size occurred above $\sim 0.5 \mathrm{~T}_{\mathrm{m}}$ when the recovery processes became dominant.

\section{- $\quad 900-1050^{\circ} \mathrm{C}$}

We have found that boundary solute segregations were completely removed after heat treatment at $1050^{\circ} \mathrm{C}$. The $\mathrm{Cr}$ element initially segregated at boundaries was captured by $\mathrm{Mn}$ enriched Si oxide particles, forming more stable Mn-enriched Cr oxides. Cell structure formed in printing was completely removed. Columnar grains in the as-built specimen experienced recrystallization and formed equiaxed grains. Dislocation segments remained in the matrix pinned by oxide particles. A number of studies have shown that homogenization and recrystallization occurred in AM $316 \mathrm{~L}$ SS at temperatures $>1000^{\circ} \mathrm{C}[19,20,22,27]$.

\subsubsection{Effect of Heat Treatment on Creep Deformation Mechanisms in AM 316L SS}

As discussed earlier, dislocation creep was the dominant creep deformation mechanism in AM 316L SS under the creep condition of $550^{\circ} \mathrm{C}$ and $275 \mathrm{MPa}$. A cell structure reduced the creep rate. The creep rate of AM 316L SS was found to be proportional to the cube of the mean cell size, $\lambda$, as shown in Eq. (2-5). According to this relationship, the lowest creep rate of the $650^{\circ} \mathrm{C}$-heat treated specimen can be attributed to its small dislocation cell size. However, Eq. (2-5) cannot explain the higher creep rates of the specimens heat treated at higher temperatures. For example, the $750^{\circ} \mathrm{C}$-heat treated specimen had a similar cell size and narrower cell walls but a higher creep rate than the $650^{\circ} \mathrm{C}$-heat treated specimen. It appears that the creep rate of the heat-treated AM 316L SS cannot be described by a single structural parameter. Ancker et al [58] suggested that small-angle dislocation boundaries are effective barriers to plastic deformation, and the effectiveness of these boundaries is dependent on their number, angle and nature. "Diffuse" smallangle boundaries cause significant hardening from high-density dislocations trapped within the boundaries. A thermal treatment sharpens the boundaries and the metal becomes softer. To account for the effects of both cell size and dislocation density within cell wall, we refer to the composite 
model developed by Mughrabi et al [64-66]. This model considers two different kinds of regions in the heterogenous cell structure to account for the long-range internal stress for crystals containing dislocation wall or cell structures: the interior of the cell wall where the local dislocation density is very high has a high "local" flow stress, and the region between them where the dislocation density is very low has a low "local" flow stress. The local flow stresses are related to the local dislocation densities, respectively. The overall flow stress, $\tau$ is given by a rule of mixture, i.e.:

$$
\tau=f_{c} \alpha_{c} G b \sqrt{\rho_{c}}+f_{w} \alpha_{w} G b \sqrt{\rho_{w}}
$$

where $\rho_{\mathrm{c}}$ and $\rho_{\mathrm{w}}$ are dislocation densities inside the cell and within the cell wall, respectively, $\mathrm{f}_{\mathrm{c}}$ and $f_{w}$ are the area (volume) fraction of cells and walls $\left(f_{c}+f_{w}=1\right)$, respectively, and $\alpha_{w}$ and $\alpha_{c}$ are the constants. The composite model describes the strengthening effect of a dislocation wall with a non-negligible thickness from three types of dislocations: dislocations in the cell walls, those in the cell interiors, and the interface dislocations that maintain compatibility. For a onedimensional dislocation wall structure, the flow stress for a heterogeneous dislocation distribution, $\tau_{\text {het }}$ is given by [66]:

$$
\tau_{\text {het }}=2 \alpha \sqrt{f_{c} f_{w}} G b \sqrt{\rho}
$$

where $\rho$ is the mean total dislocation density. Orlova [67] extended the composite model to hightemperature creep, and proposed that the relationship of the subgrain/cell size, $\lambda$ and the total dislocation density, $\rho$ is dependent on the volume fraction of the sub-boundaries, $\mathrm{f}_{\mathrm{w}}$ :

$$
\lambda=C\left(f_{w}\right) \rho^{-0.5}
$$

Based on these theories, Eq. (2-5) can be modified to account for the effect of dislocation cell walls on the creep rate:

$$
\frac{\dot{\varepsilon}}{D}=A^{\prime \prime}\left(\frac{\lambda}{b f_{w}}\right)^{m}\left(\frac{\sigma}{G}\right)^{n}
$$

where $\mathrm{m}$ is the constant. According to Eq. (3-4), the $750^{\circ} \mathrm{C}$-heat treated specimen is expected to have a higher creep rate than the $650^{\circ} \mathrm{C}$-heat treated specimen because of its thinner cell wall (and therefore a smaller volume fraction, $\mathrm{f}_{\mathrm{w}}$ ) and the comparable cell size $(\lambda)$. A further increase of the heat treatment temperature to $800^{\circ} \mathrm{C}$ resulted in significant cell coarsening and wall sharpening, further increasing the creep rate. The heat treatment at $900^{\circ} \mathrm{C}$ leads to formation of subgrain boundaries while subgrain size is relatively unchanged when compared with the cell size of the $800^{\circ} \mathrm{C}$-heat treated specimen. To rationalize the high creep rate of the $900^{\circ} \mathrm{C}$-heat treated specimen different strengthening effects of dislocation cells and subgrains must be considered. Thompson [68] discussed substructure strengthening mechanisms by considering cells produced at low temperature and subgrains produced at higher temperatures. The shear flow stress, $\tau$ is generalized by:

$$
\tau=\tau_{0}+k G b \lambda^{-p}
$$

where $\lambda$ is the cell/subgrain size, $\tau_{0}$ is the friction stress, $\mathrm{k}$ and $\mathrm{p}$ are the constants. The substructure size dependence, $\mathrm{p}$ varies from 1 for dislocation cells to 0.5 for subgrains, and $0.5<\mathrm{p}<1$ for intermediate cases. Dislocation cells behave like dislocation forests and are penetrable by gliding dislocations. Subgrain boundaries are regarded as impenetrable, and subgrains behave like grains following a Hall-Petch relation. Similar strengthening effects of cells and subgrains can be applied to Eq. (3-4). It is hypothesized that the substructure size dependence, $m$ can vary from 3 suggested 
by Sherby et al [45] for dislocation cells to a smaller value for subgrains. Subgrains formed in the $900^{\circ} \mathrm{C}$-heat treated specimen are less effective in reducing the creep rate relative to dislocation cells.

It is noted that the post-build heat treatment strongly affects the strain to the onset of tertiary creep (SOTC). The SOTC indicates the length of the steady-state, i.e. the stability of the substructure under creep. It is noted that the SOTC was $<1 \%$ in the as-built, $650^{\circ} \mathrm{C}$-and $700^{\circ} \mathrm{C}$ heat treated specimens and increased considerably after heat treatments at higher temperatures. The low SOTC values implies that the cell structures produced during the AM process are unstable under creep. The subgrain structure formed after the $900^{\circ} \mathrm{C}$ heat treatment is more stable but less effective in reducing the creep rate. Presence of oxide particles enhances dislocation pinning in AM 316L SS through the Orowan mechanism, and it was recently demonstrated by 3D dislocation dynamics simulations [22]. Different chemical composition in cell walls provides a local solution strengthening effect and also play a role in stabilizing cell structures [22]. Furthermore, a highdensity of stacking faults can impede cross slip, and an increase in $\mathrm{Cr}$ within cell walls can decrease the stacking fault energy which affects creep resistance [69]. These structural features should be considered in enhancing the creep resistance of AM 316L SS. Saeidi et al [32] have shown that oxide nanoparticles can be introduced to $316 \mathrm{~L}$ by laser melting and the oxide-dispersedstrengthened (ODS) AM 316L SS has high yield and tensile strength. The lower creep rate of the $1050^{\circ} \mathrm{C}$-heat treated specimen, though having no cell/subgrain structures may be attributed to oxide particles pinning the dislocations in the matrix.

We have shown that there is a minimal effect of the heat treatment on tertiary creep of AM 316L SS. Tertiary creep can result from necking or from the development of intergranular cavities and cracks. Tertiary creep of AM 316L SS is dominated by intergranular cavitation and cracking, as shown in Fig. 3-6. The creep void growth rate was explained by the constrained cavity growth model earlier with a key assumption that the cavity nucleation time was minimal in AM 316 L SS because of the existence of porosity, and it was the cavity growth time that controls the creep life. The kinetics of cavity growth at grain boundaries was suggested to be controlled by coupled diffusion and power-law creep, i.e. voids grow by diffusion but at a rate limited by the power-law creep of the surrounding material. The effect of heat treatment on the creep life of AM 316L SS can be rationalized by considering the effect of the heat treatment on the minimum/secondary creep rate of AM 316L SS. Both this study and work by Ronneberg et al [23] have shown that the heat treatments have an insignificant effect on porosity in the as-built specimen, which justifies the insensitivity of the tertiary creep strain to the post-build heat treatment. However, Tascioglu at al [23] reported that porosity decreased with increasing heat treatment temperature. Future work is needed to clarify the effect of the heat treatment on porosity in AM 316L SS. 


\section{Fatigue Performance of Printed Rods and Plates of AM 316L SS}

\subsection{Experimental}

Fatigue specimens used in this study were ASTM standard-sized round bar specimens. Specimens had a gauge diameter of 0.215 in, a gauge length of 0.64 in and a total length of 4.0 in (shown in Fig. 4-1). Specimens were fabricated from two different builds, Build 20190315M2 (shown in Fig. 4-2) and Build 20201009M2 (shown in Fig. 4-3) of AM 316L SS printed by an LPBF process using a Concept Laser-M2 printer at Oak Ridge National Laboratory. Praxair 316L stainless steel powder (composition given in Table 2-1) and default printer settings were used for printing.

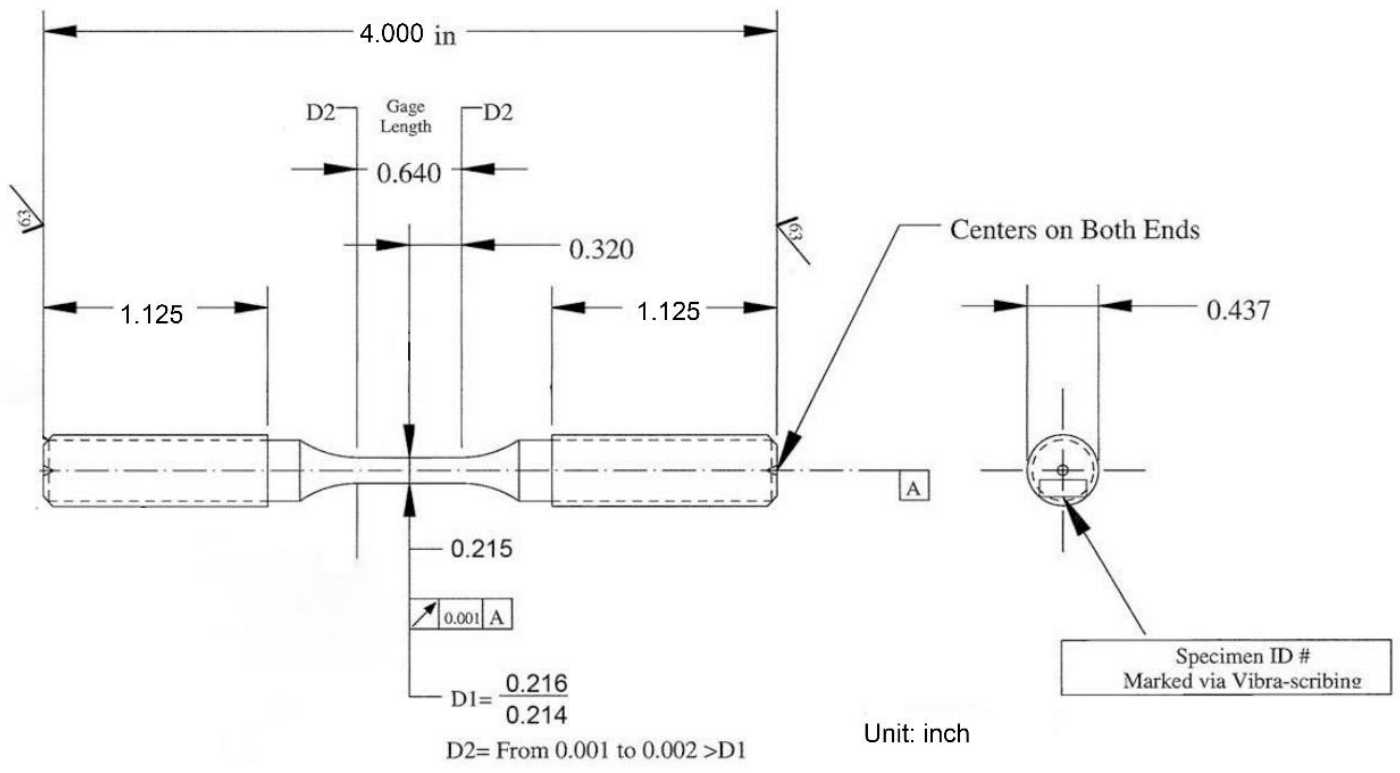

Figure 4-1. Schematic drawing of a fatigue specimen.

Fatigue specimens from Build 20190315M2 were fabricated from printed rods, and hereafter are called "Rod specimens". Rods have a nominal diameter of 0.5 " and a nominal length of 4.1", and were printed vertically, either by laser 1, laser 2 or both lasers, as shown in Fig. 4-2. Each rod had a unique ID, and the ID number was printed on the top end of the rod. Specimens had the same IDs as the rods, with IDs of "L1-X" for rods printed by laser and "L2-X" for rods printed by laser 2 . One specimen per printed rod was machined, and the axial direction of the specimen was along the build direction. The rod samples are listed in Table 4-1.

Fatigue specimens were also machined from the plates of Build 20201009M2 in two build orientations, as shown in Fig. 4-3. Each plate of Build 20201009M2 was assigned a unique ID to keep track of their locations. The ID of the plate was printed on the top surface of the plate. Plates printed by laser 1 have IDs of L1-X; plates printed by laser 2 had IDs of L2-X. Specimens in the horizontal direction have the loading axis normal to the build direction and have IDs of X-YH, where " $\mathrm{X}$ " is the plate number, "Y" indicates the location of the specimen from a specific plate, 
and " $\mathrm{H}$ " refers to the horizontal direction. These specimens are hereafter called "Horizontal plate specimens". Specimens in the vertical direction have the loading axis parallel to the build direction and have IDs of $\mathrm{X}-\mathrm{YV}$, where " $\mathrm{X}$ " is the plate number, "Y" is the location number, and "V" refers to the vertical direction. These specimens are hereafter called "Vertical plate specimens". Focus of this study is to evaluate the effects of internal defects and microstructure on fatigue properties of AM materials. Surface topographic influences were excluded. Table 2-1 lists the horizontal plate specimens and vertical plate specimens reported here.
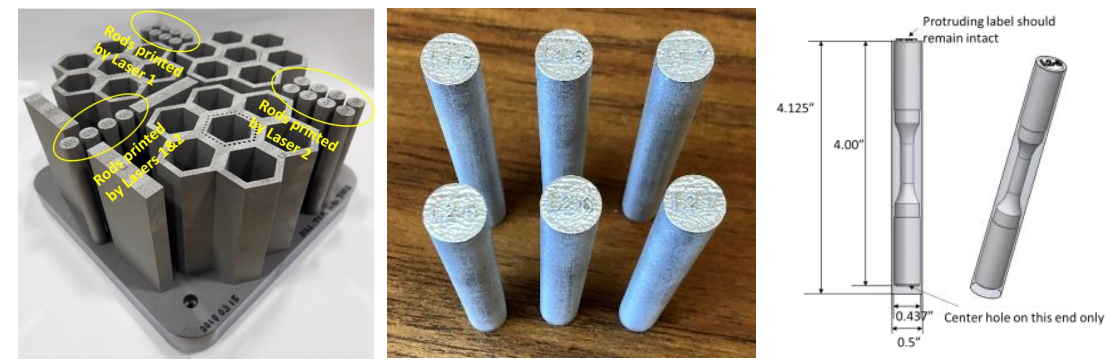

Figure 4-2. Fatigue specimens were made from rods printed by Laser 1, Laser 2, of Build $20190315 \mathrm{M} 2$.
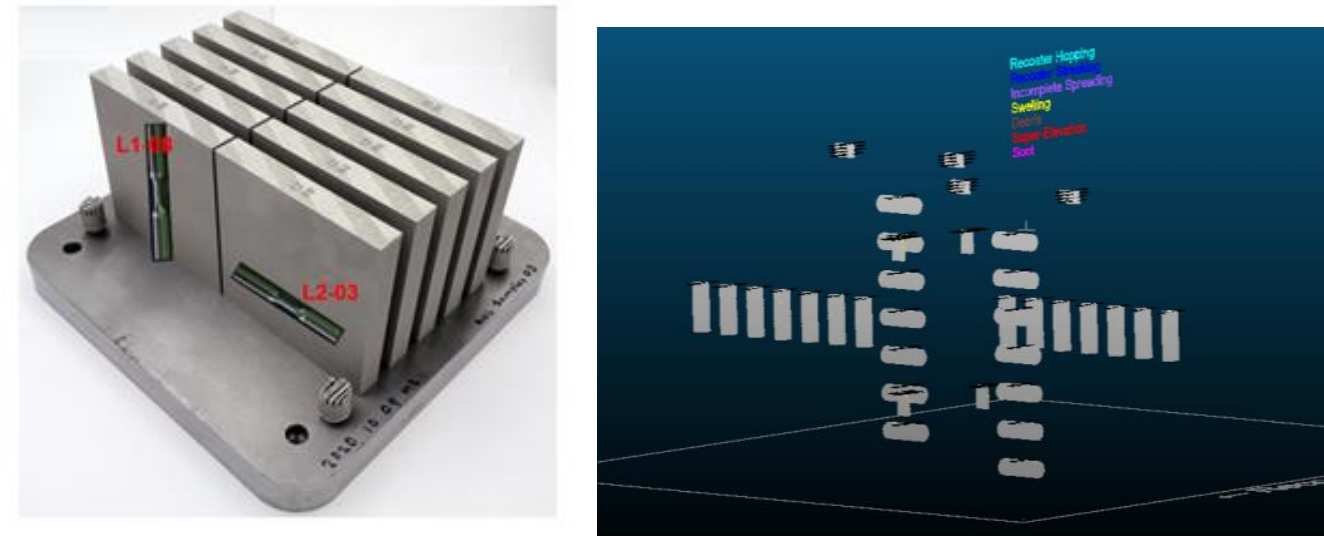

Figure 4-3. Fatigue specimens were made plates of Build 20201009M2 in the horizontal and vertical directions.

Fatigue tests were performed according to ASTM Standard E606/606M-12, "Standard Test Methods for Strain-Controlled Fatigue Testing." Tests were carried out on a closed-loop servohydraulic test frame at Argonne National Laboratory. Specimen heating was provided by a threezone split furnace. The test temperature was controlled and monitored by two Type K thermocouples wired at the top and bottom grip sections of the specimen. All the tests were carried out at $550^{\circ} \mathrm{C}$ in air on the same machine. Tests were carried out under a constant total strain amplitude in fully reversed $(\mathrm{R}=-1)$ strain control. A high temperature extensometer was mounted at the uniform gauge section of the specimen to measure and control the total axial strain. The strain rates in tension and compression were kept the same, $0.001 \mathrm{~s}^{-1}$. Instron WaveMatrix ${ }^{\mathrm{TM}}$ Dynamic Software was used for test control and data acquisition. The stress-strain hysteresis loop 
and maximum and minimum stresses of a cycle were recorded at intervals throughout the test. The number of cycles to failure is defined as the number of cycles when the stress amplitude is reduced by approximately $50 \%$ of the maximum stress amplitude or the final recorded cycle when an instability of the test occurred.

The microstructure of fatigue-tested specimens was characterized by optical microscopy (OM), scanning electron microscopy (SEM), transmission electron microscopy (TEM), and synchrotron X-ray tomography. The gauge section of a broken half of a fatigue-tested specimen was examined non-destructively by synchrotron high-energy X-ray tomography for porosity and fatigue cracks at the beamline 1-ID at the Advanced Photon Source at Argonne National Laboratory. The other broken half of a fatigue-tested specimen was sectioned along the specimen gauge for examination by OM and SEM. TEM discs were made from the gauge section of the fatigue-tested specimen perpendicular to the loading axis for microstructure characterization.

Table 4-1. List of fatigue specimens and fatigue testing conditions.

\begin{tabular}{|c|c|c|c|c|c|c|}
\hline $\begin{array}{c}\text { Specimen } \\
\text { ID }\end{array}$ & Build \# & $\begin{array}{c}\text { Print } \\
\text { Geometry }\end{array}$ & $\begin{array}{c}\text { Build } \\
\text { Orientation }\end{array}$ & $\begin{array}{c}\text { Rod/Plate } \\
\text { ID }\end{array}$ & $\begin{array}{c}\text { Strain amp } \\
(\boldsymbol{\%})\end{array}$ & $\begin{array}{c}\text { Temp }\left(^{\circ}\right. \\
\text { C) }\end{array}$ \\
\hline L1-5 & $20190315 \mathrm{M} 2$ & Rod & Vertical & L1-5 & 0.5 & 550 \\
\hline L1-6 & $20190315 \mathrm{M} 2$ & Rod & Vertical & L1-6 & 0.3 & 550 \\
\hline L1-7 & $20190315 \mathrm{M} 2$ & Rod & Vertical & L1-7 & 0.2 & 550 \\
\hline L2-5 & $20190315 \mathrm{M} 2$ & Rod & Vertical & L2-5 & 0.5 & 550 \\
\hline L2-6 & $20190315 \mathrm{M} 2$ & Rod & Vertical & L2-6 & 0.4 & 550 \\
\hline L2-7 & $20190315 \mathrm{M} 2$ & Rod & Vertical & L2-7 & 0.25 & 550 \\
\hline $3-1 \mathrm{H}$ & $20201009 \mathrm{M} 2$ & Plate & Horizontal & L2-03 & 0.2 & 550 \\
\hline $3-2 \mathrm{H}$ & $20201009 \mathrm{M} 2$ & Plate & Horizontal & L2-03 & 0.5 & 550 \\
\hline $3-3 \mathrm{H}$ & $20201009 \mathrm{M} 2$ & Plate & Horizontal & L2-03 & 0.3 & 550 \\
\hline $3-4 \mathrm{H}$ & $20201009 \mathrm{M} 2$ & Plate & Horizontal & L2-03 & 0.4 & 550 \\
\hline $3-5 \mathrm{H}$ & $20201009 \mathrm{M} 2$ & Plate & Horizontal & L2-03 & 0.35 & 550 \\
\hline $3-6 \mathrm{H}$ & $20201009 \mathrm{M} 2$ & Plate & Horizontal & L2-03 & 0.25 & 550 \\
\hline $8-1 \mathrm{~V}$ & $20201009 \mathrm{M} 2$ & Plate & Vertical & L1-08 & 0.2 & 550 \\
\hline $8-2 \mathrm{~V}$ & $20201009 \mathrm{M} 2$ & Plate & Vertical & L1-08 & 0.4 & 550 \\
\hline $8-3 \mathrm{~V}$ & $20201009 \mathrm{M} 2$ & Plate & Vertical & L1-08 & 0.3 & 550 \\
\hline $8-4 \mathrm{~V}$ & $20201009 \mathrm{M} 2$ & Plate & Vertical & L1-08 & 0.25 & 550 \\
\hline $8-5 \mathrm{~V}$ & $20201009 \mathrm{M} 2$ & Plate & Vertical & L1-08 & 0.35 & 550 \\
\hline $8-6 \mathrm{~V}$ & $20201009 \mathrm{M} 2$ & Plate & Vertical & L1-08 & 0.45 & 550 \\
\hline
\end{tabular}




\subsection{Results}

\subsubsection{Strain-Life Curves}

Strain - life curves are shown in Fig. 4-4 in terms of total strain amplitude vs. fatigue life for rod specimens, horizontal plate specimens (Plate L2-03), and vertical plate specimens (Plate L1-08) tested at $550^{\circ} \mathrm{C}$. The fatigue lives of horizontal plate specimens and the rod specimens were similar at high strain amplitudes, while the horizontal plate specimens have longer fatigue lives at low strain amplitudes than the rod specimens. The vertical plate specimens behaved similarly as the horizontal plate specimens but showed more significant data scatter.

Figure 4-5 compares the strain-life data between AM 316L SS in this study and wrought 316 SS reported by Tavassoli et al [70]. The rod specimens of AM 316L SS have shorter fatigue lives than wrought 316 SS. However, the plate specimens have comparable fatigue lives at low strain amplitudes but shorter lives at high strain amplitudes.

Hysteresis loops at the half-life are shown in Figs. 4-6(a), (b) and (c) for rod specimens, horizontal plate specimens (Plate L2-03), and vertical plate specimens (Plate L1-08), respectively, at various strain amplitudes. It is noted that hysteresis loops show serrations when the strain amplitude was $>0.25 \%$. Flow stress serrations were observed in both tensile and compressive directions and they behaved similarly in both directions. The serrations were more pronounced at a higher strain amplitude. Serrations in flow stress under cyclic loading in 316 stainless steel are attributed with the dynamic strain aging (DSA) effect [71].

It is known that the total strain amplitude, $\Delta \varepsilon_{t} / 2$ for a fully-reversed, strain-controlled test can be expressed as:

$$
\frac{\Delta \varepsilon_{t}}{2}=\frac{\Delta \varepsilon_{e}}{2}+\frac{\Delta \varepsilon_{p}}{2}=\frac{\Delta \sigma}{2 E}+\frac{\Delta \varepsilon_{p}}{2}
$$

where $\Delta \varepsilon_{\mathrm{e}} / 2$ and $\Delta \varepsilon_{\mathrm{p}} / 2$ are the elastic and plastic strain amplitudes, respectively. $\Delta \sigma / 2$ is the stress amplitude, and $\mathrm{E}$ is the Young's modulus. It should be noted that plastic strain and inelastic strain are not differentiated here. The elastic and plastic strain amplitudes were determined at the halflife, and are plotted in Fig.4-7 as a function of fatigue life for rod specimens, horizontal plate specimens (Plate L2-03), and vertical plate specimens (Plate L1-08). The strain-life relations were determined by fitting the date to the Coffin-Manson and Basquin equation:

$$
\frac{\Delta \varepsilon_{t}}{2}=\underbrace{\frac{\sigma_{f}^{\prime}}{E}\left(N_{f}\right)^{b}}_{\text {elastic }}+\underbrace{\varepsilon_{f}^{\prime}\left(N_{f}\right)^{c}}_{\text {plastic }}
$$

where $N_{f}$ is the cycles to failure, $\sigma_{f}$ ' is the fatigue strength coefficient, $b$ is the fatigue strength exponent, $\varepsilon_{f}$ ' is the fatigue ductility coefficient, and $c$ is the fatigue ductility exponent. The strainlife equations for the rod specimens and the horizontal plate specimens (Plate L2-03) are given in Fig. 4-7. It is interesting to note that the elastic strain-life curves are the same for the rod and plate specimens, while the plastic strain-life curves are different. The fatigue ductility exponent, c changed from -0.537 for the rod specimens to -0.397 for the horizontal plate specimens, resulting in significantly improved fatigue life at low strain amplitudes. 


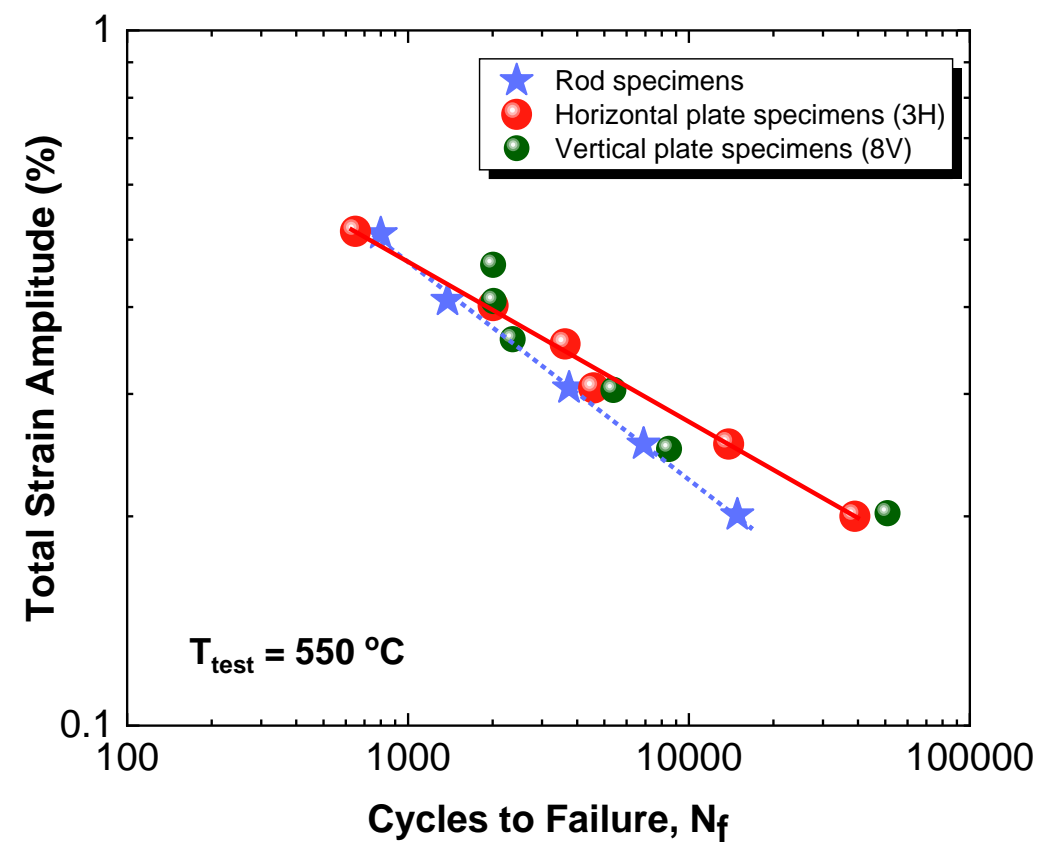

Figure 4-4. Total strain amplitude vs. fatigue life for rod specimens, horizontal plate specimens (Plate L2-03), and vertical plate specimens (Plate L1-08) of AM 316L SS tested at $550^{\circ} \mathrm{C}$.

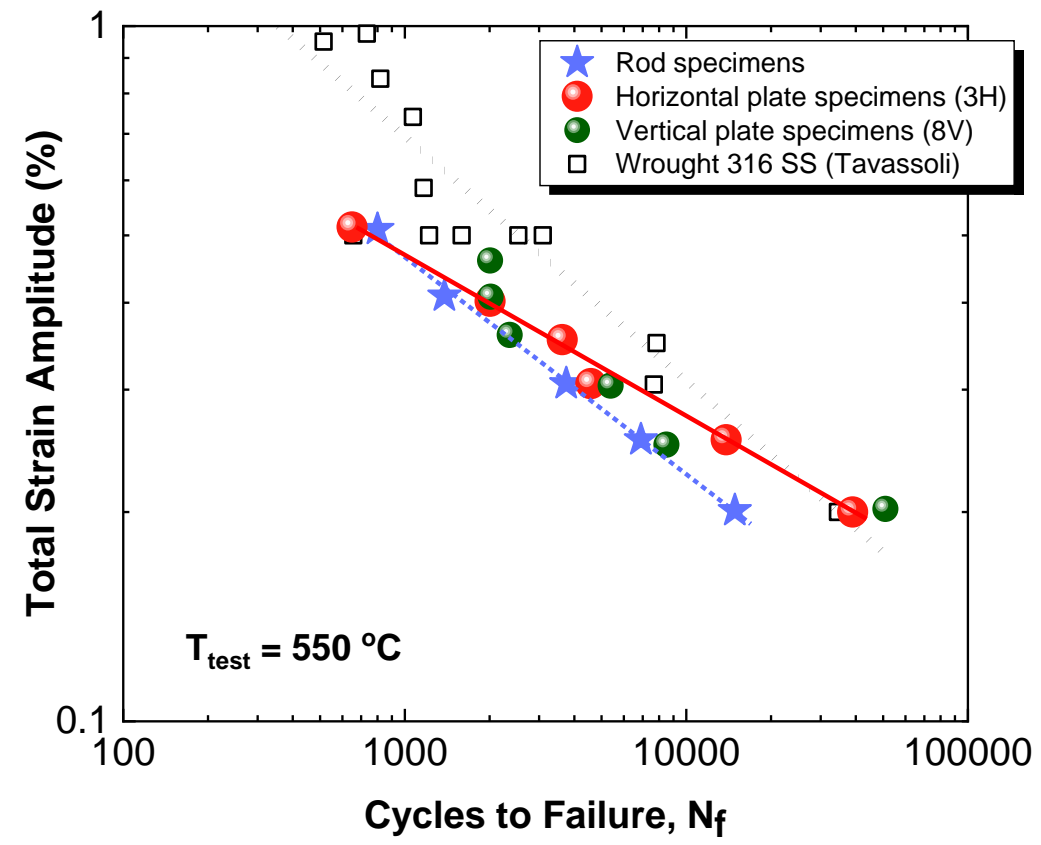

Figure 4-5. Comparison of strain - life data between AM 316L SS and wrought $316 \mathrm{SS}$ at $550^{\circ} \mathrm{C}$. 


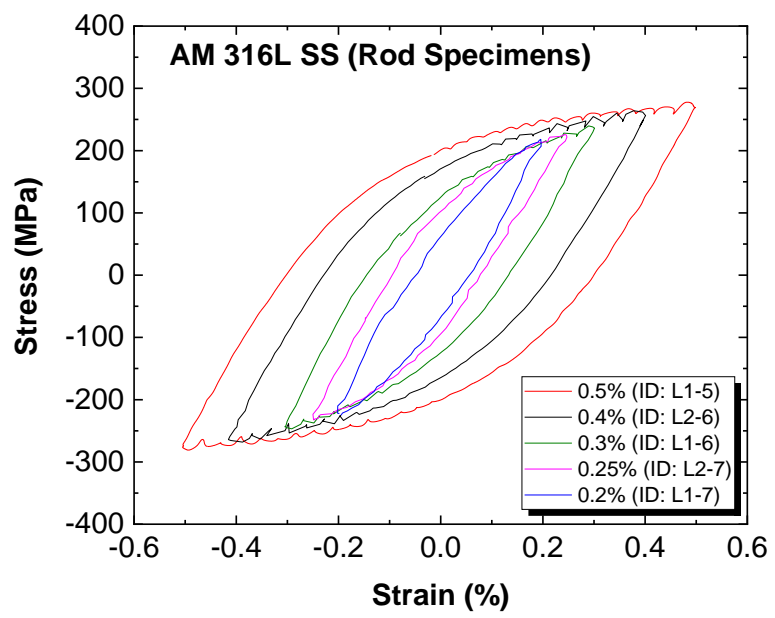

(a)
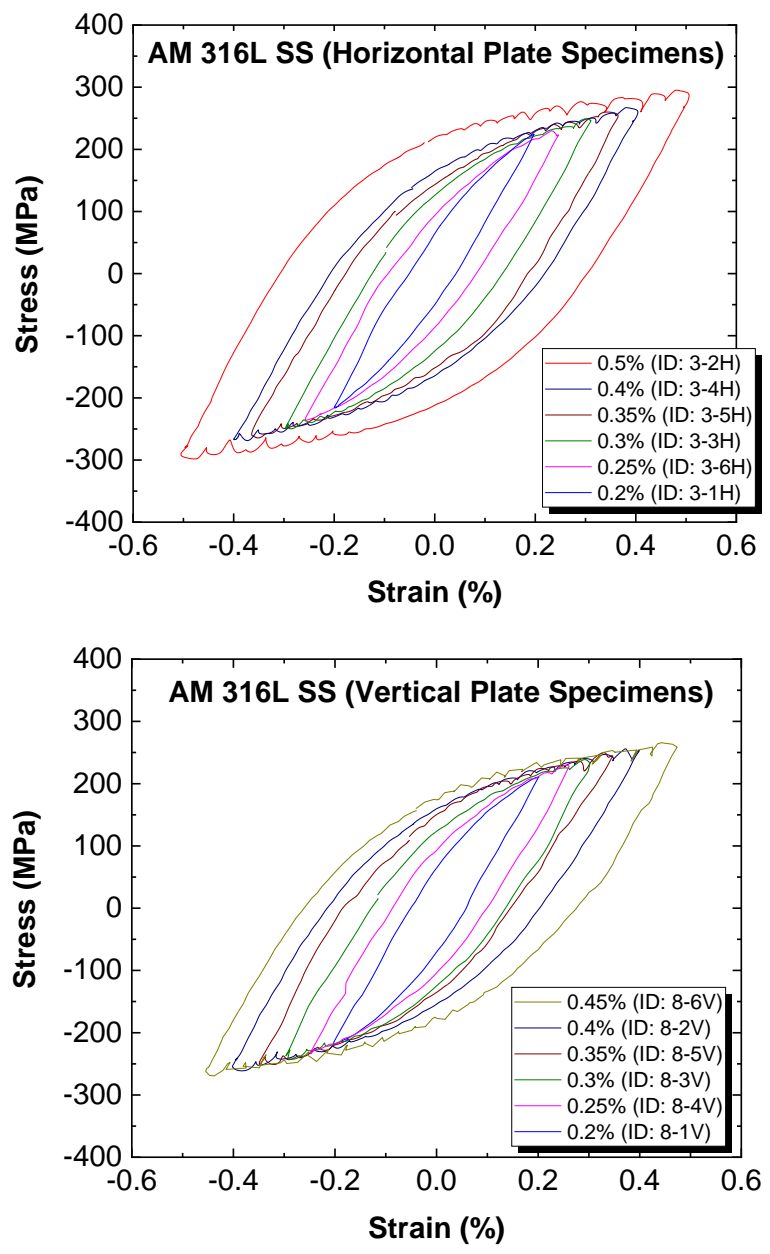

(b)

(c)

Figure 4-6. Hysteresis loops at the half-life for (a) rod specimens, (b) horizontal plate specimens (Plate L2-03), and (c) vertical plate specimens (Plate L1-08). 


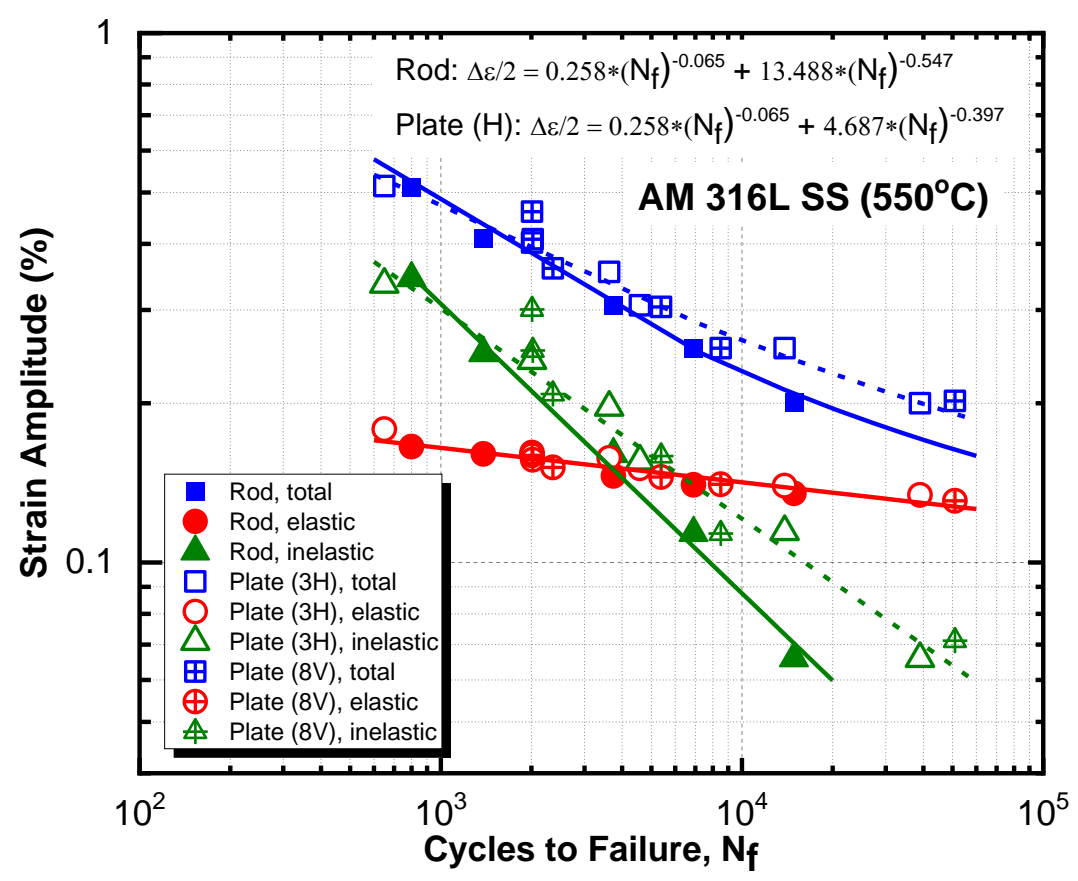

Figure 4-7. Total, plastic, and elastic strain amplitude vs. life for rod specimens, horizontal plate specimens (Plate L2-03), and vertical plate specimens (Plate L1-08).

\subsubsection{Cyclic Stress Response}

The cyclic stress response of rod specimens, horizontal plate specimens (Plate L2-03), and vertical plate specimens (Plate L1-08) is shown in Figs. 4-8(a), (b) and (c), respectively, where the stress amplitude is plotted as a function of cycles. All the specimens exhibit similar cyclic stress response. In the initial transient stage ( $<10$ cycles), the stress amplitude decreases with increasing cycles when the strain amplitude is $<0.3 \%$, and increases when the strain amplitude is $>0.3 \%$. After the initial transient, the stress amplitude continues to decrease with increasing cycles (i.e. cyclic softening) until failure under all the strain amplitudes. It is noted that specimens tested at the strain amplitude of $0.5 \%$ failed prematurely before the onset of a significant load drop.

Cyclic stress - strain curves were generated from the values of the stress amplitude at the half-life and the strain amplitude, and they are shown in Fig. 4-9. Rod and plate specimens behave similarly below $0.5 \%$. 

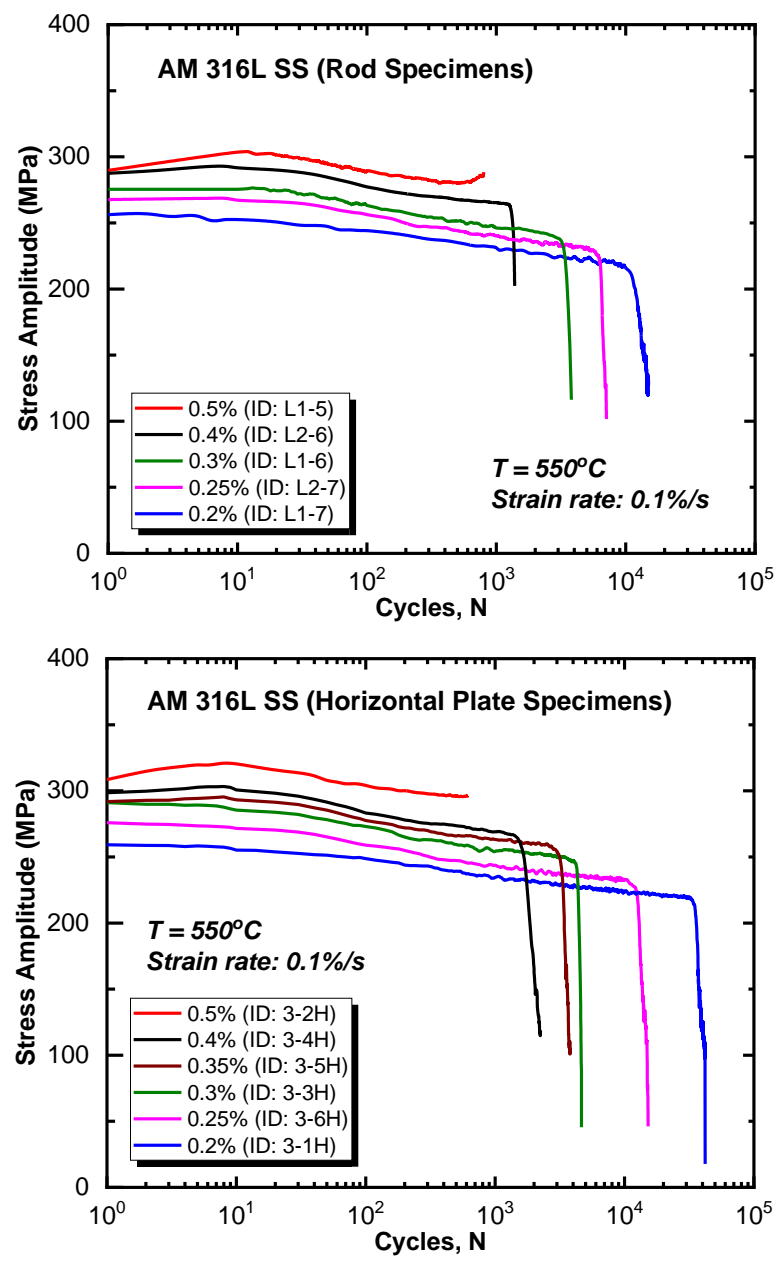

(a)

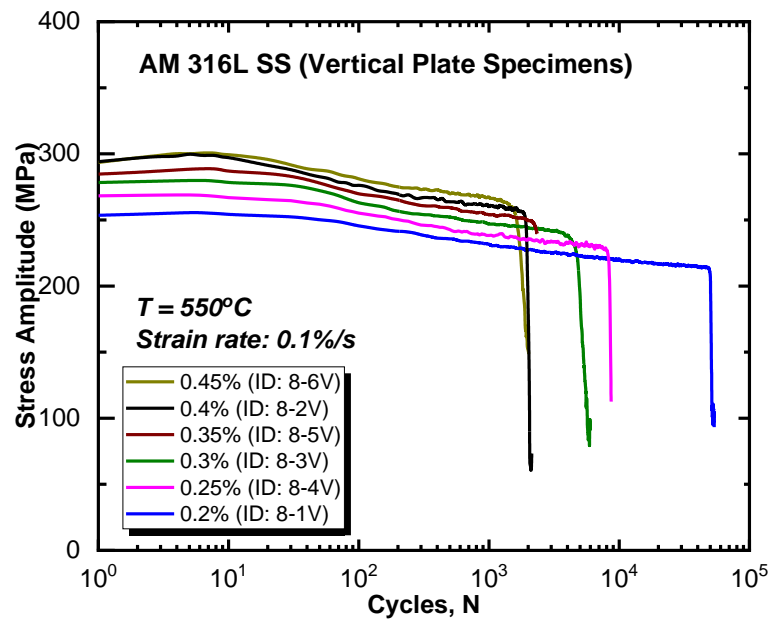

(b)

(c)

Figure 4-8. Stress amplitude vs. cycles for (a) rod specimens, (b) horizontal plate specimens (Plate L2-03), and (c) vertical plate specimens (Plate L1-08). 


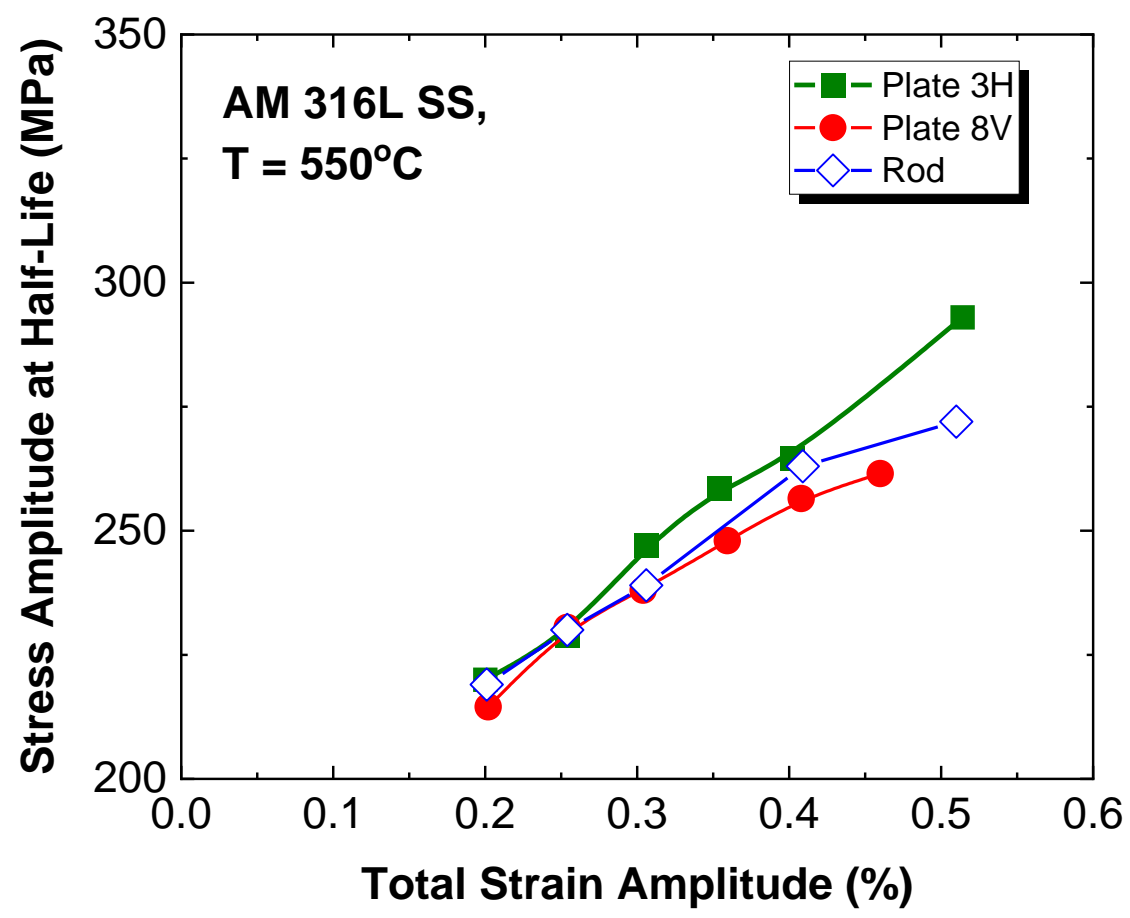

Figure 4-9. Cyclic stress - strain curves for rod specimens, horizontal plate specimens (Plate L203), and vertical plate specimens (Plate L1-08).

\subsubsection{Microstructural Evolution under Cyclic Loading}

Dislocation structures of fatigue-tested specimens was examined by TEM. Figure 4-10 shows the microstructure of a rod specimen in the as-built condition (top row), rod specimen, L17 after fatigue test at $550^{\circ} \mathrm{C}, 0.2 \%$ (middle row), and rod specimen, $\mathrm{L}-15$ after fatigue test at $550^{\circ} \mathrm{C}$, $0.5 \%$ (bottom row). Dislocation cells resulting from printing largely remained after fatigue tests. The mean size of dislocation cells showed a minimal change after fatigue test at $0.5 \%$, but cell wall thickness was reduced with reduced dislocation density within cell walls, indicating a recovery process under fatigue loading. On the other hand, cell wall thickness increased with increased dislocation density within cell walls, and cell well boundaries were poorly-defined after fatigue test at $0.2 \%$.

Compared with rod specimens, plate specimens had smaller cells and but similar wall thicknesses, as shown in Fig. 4-11 where dislocation structures and distributions of dislocation cells and cell wall thickness are shown for a plate specimen in the as-built condition (top row), horizontal plate specimen, $3-1 \mathrm{H}$ after fatigue test at $550^{\circ} \mathrm{C}, 0.2 \%$ (middle row), and horizontal plate specimen, $3-2 \mathrm{H}$ after fatigue test at $550^{\circ} \mathrm{C}, 0.5 \%$ (bottom row). Dislocation cell structures showed similar changes in the plate specimen to these in the rod specimen. 

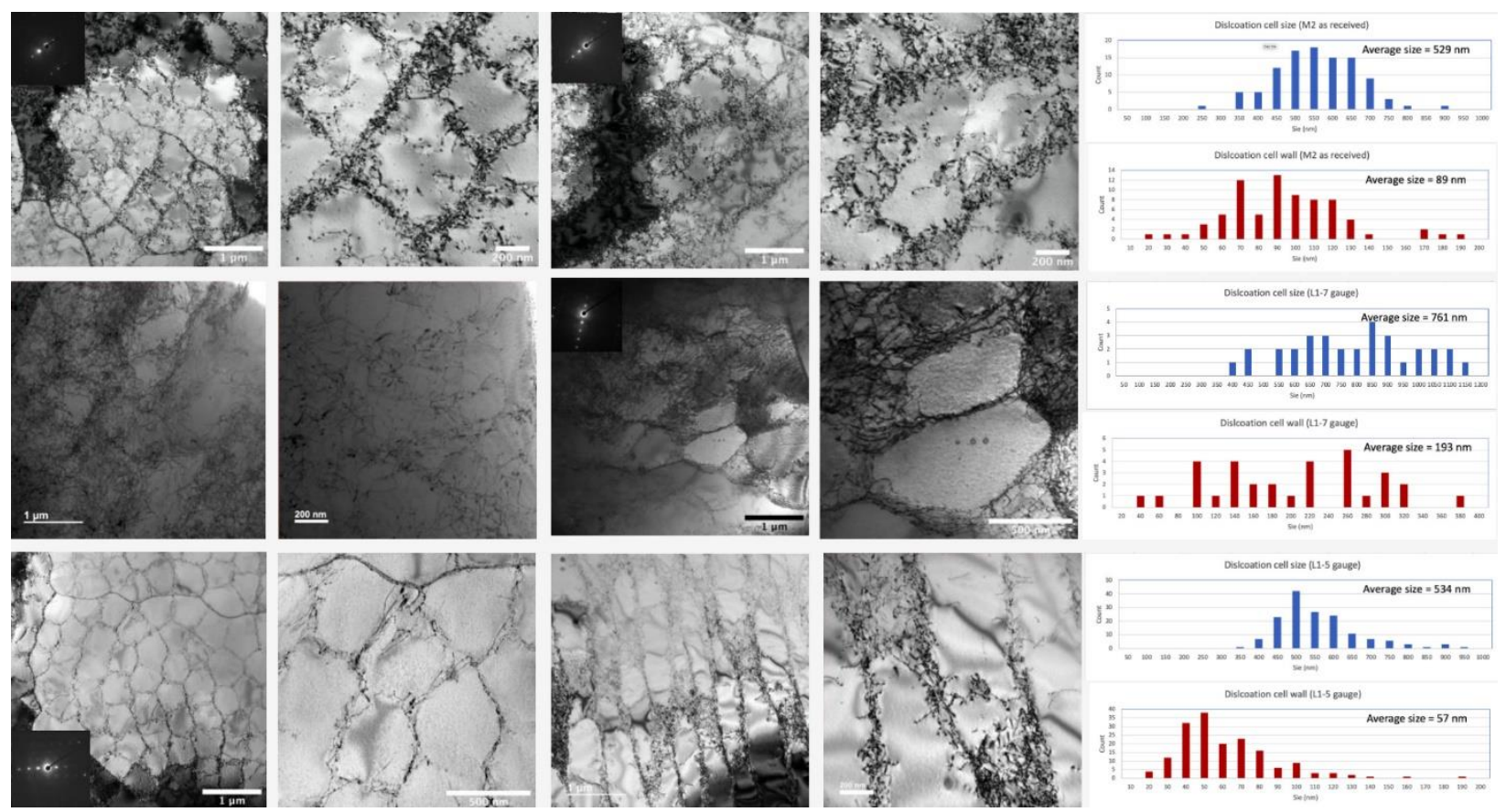

Figure 4-10. TEM images showing dislocation structures and distributions of dislocation cells and cell wall thickness: top row - as-built rod; middle row - rod specimen, L1-7 $\left(550^{\circ} \mathrm{C}, 0.2 \%\right)$; bottom row - rod specimen, L-5 $\left(550^{\circ} \mathrm{C}, 0.5 \%\right)$.
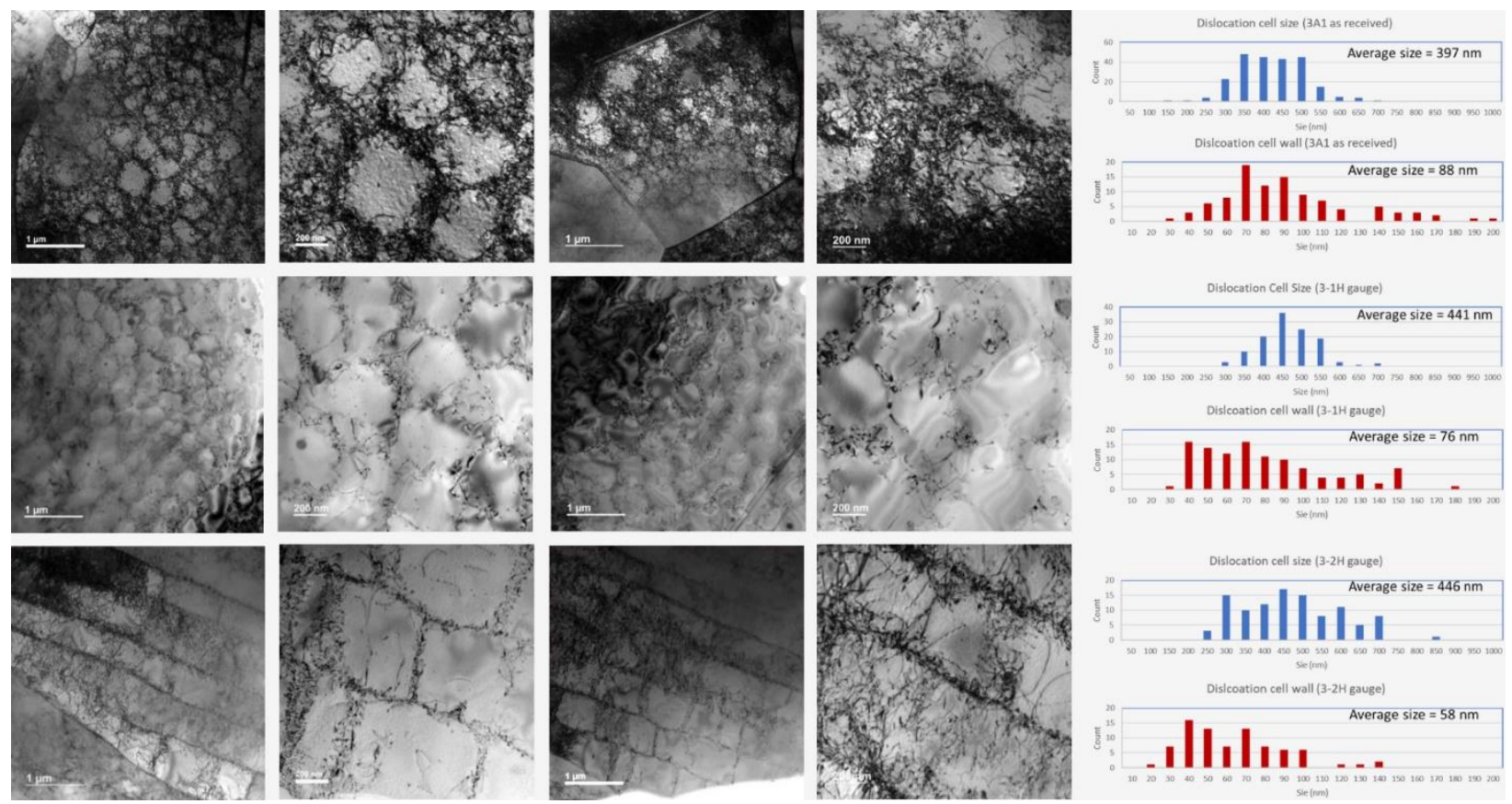

Figure 4-11. TEM images showing dislocation structures and distributions of dislocation cells and cell wall thickness: top row - as-built plate L2-03; middle row - horizontal plate specimen, $3-1 \mathrm{H}\left(550^{\circ} \mathrm{C}, 0.2 \%\right)$; bottom row - horizontal plate specimen, $3-2 \mathrm{H}\left(550^{\circ} \mathrm{C}, 0.5 \%\right)$. 
Microstructure of the grip and gauge sections of the rod and plate specimens after fatigue test was characterized by SEM to examine the grain and cell structural changes on the mesoscale level. Figures 4-12 to 4-14 present SEM images at various magnifications showing the microstructure of the gauge section of rod specimen, L1-7 after fatigue test at $550^{\circ} \mathrm{C}$ and $0.2 \%$ (Fig. 4-12), the grip section (Fig. 4-13(a)) and the gauge section (Fig. 4-13(b)) of horizontal plate specimen, $3-1 \mathrm{H}$ after fatigue test at $550^{\circ} \mathrm{C}$ and $0.2 \%$, and the microstructure of the grip section (Fig. 4-14(a) and the gauge section (Fig. 4-14(b)) of vertical plate specimen, 8-2V after fatigue test at $550^{\circ} \mathrm{C}$ and $0.4 \%$. The global view of microstructure given in Figs. 4-12 to 4-14 shows qualitatively insignificant changes in cell structures under fatigue loading in rod, horizontal and vertical plate specimens of AM 316L SS.
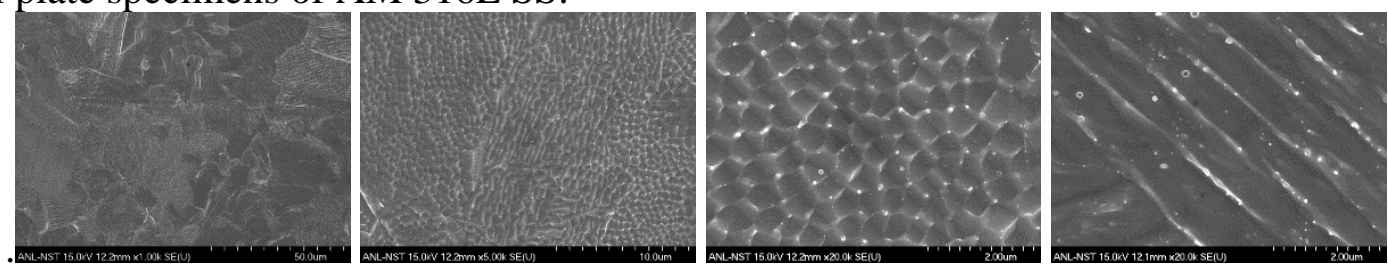

Figure 4-12. SEM images at various magnifications showing the microstructure of the gauge section of rod specimen, L1-7 after fatigue test at $550^{\circ} \mathrm{C}$ and $0.2 \%$.
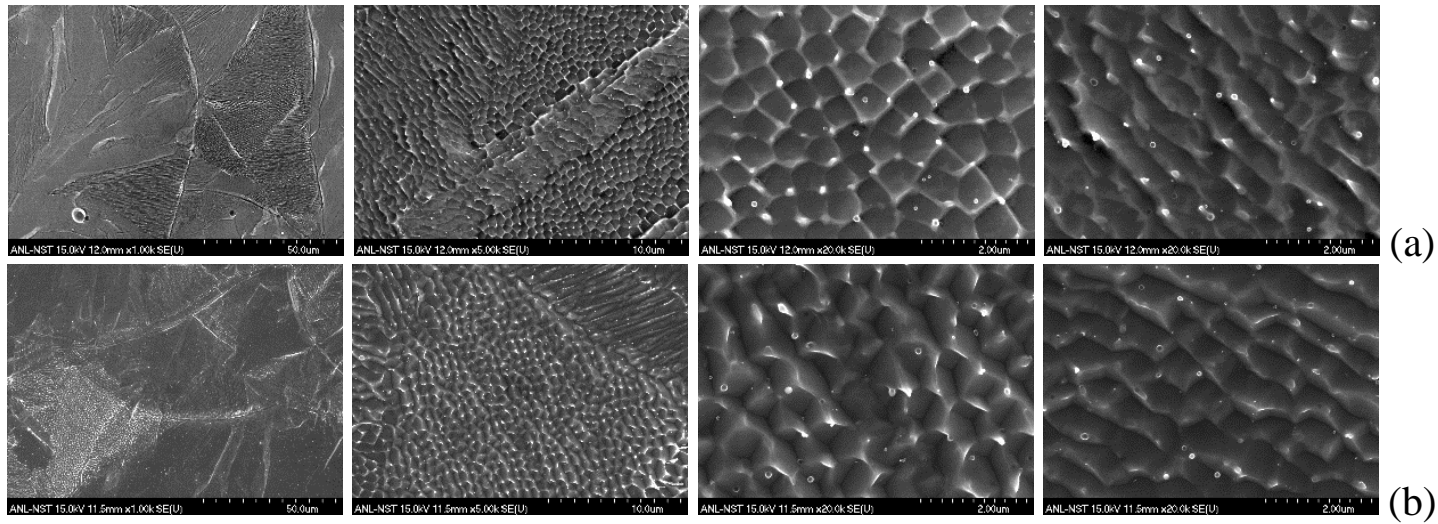

Figure 4-13. SEM images at various magnifications showing the microstructure of (a) the grip section and (b) the gauge section of horizontal plate specimen, $3-1 \mathrm{H}$ after fatigue test at $550^{\circ} \mathrm{C}$
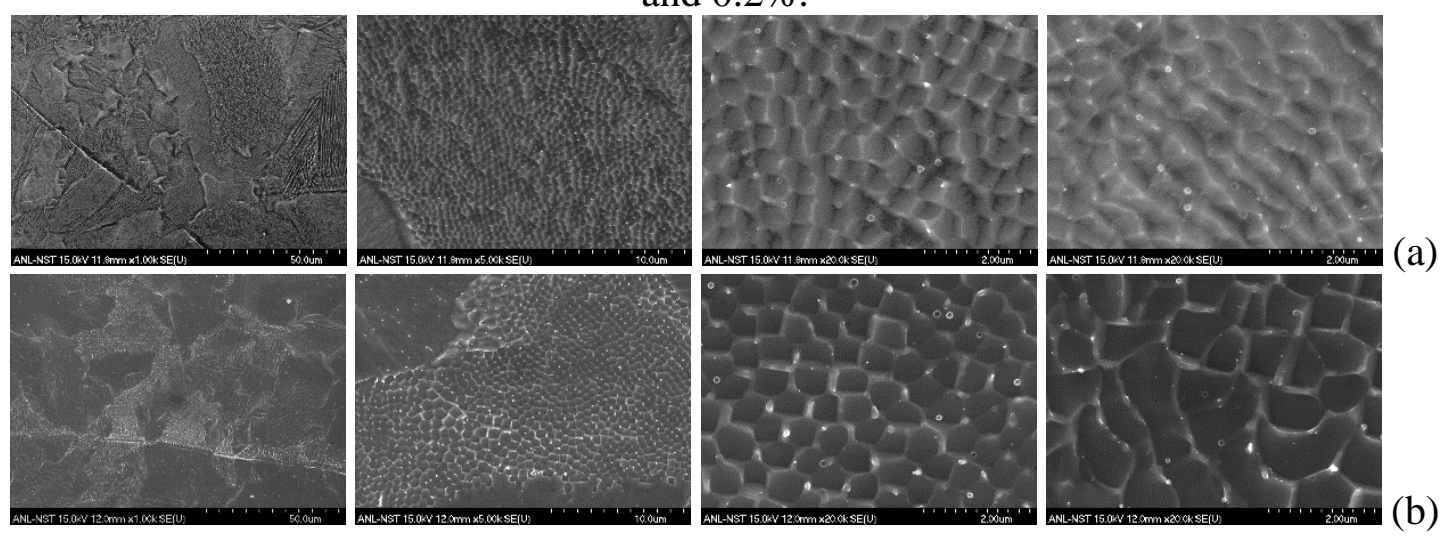

Figure 4-14. SEM images at various magnifications showing the microstructure of (a) the grip section and (b) the gauge section of vertical plate specimen, $8-2 \mathrm{~V}$ after fatigue test at $550^{\circ} \mathrm{C}$ and $0.4 \%$. 
Figure 4-15(a) is a composite back-scattering SEM image of the longitudinal cross section of rod specimen, L2-5 showing internal porosity and cracks after fatigue test interrupted at 220 cycles at $550^{\circ} \mathrm{C}$ and $0.5 \%$. High-magnification images are given in Fig. 4-15(b) showing fatigue cracks developed in the interior of the specimen. Internal defects (porosity, cracks) formed during printing are likely the initiation sites of internal fatigue cracks.

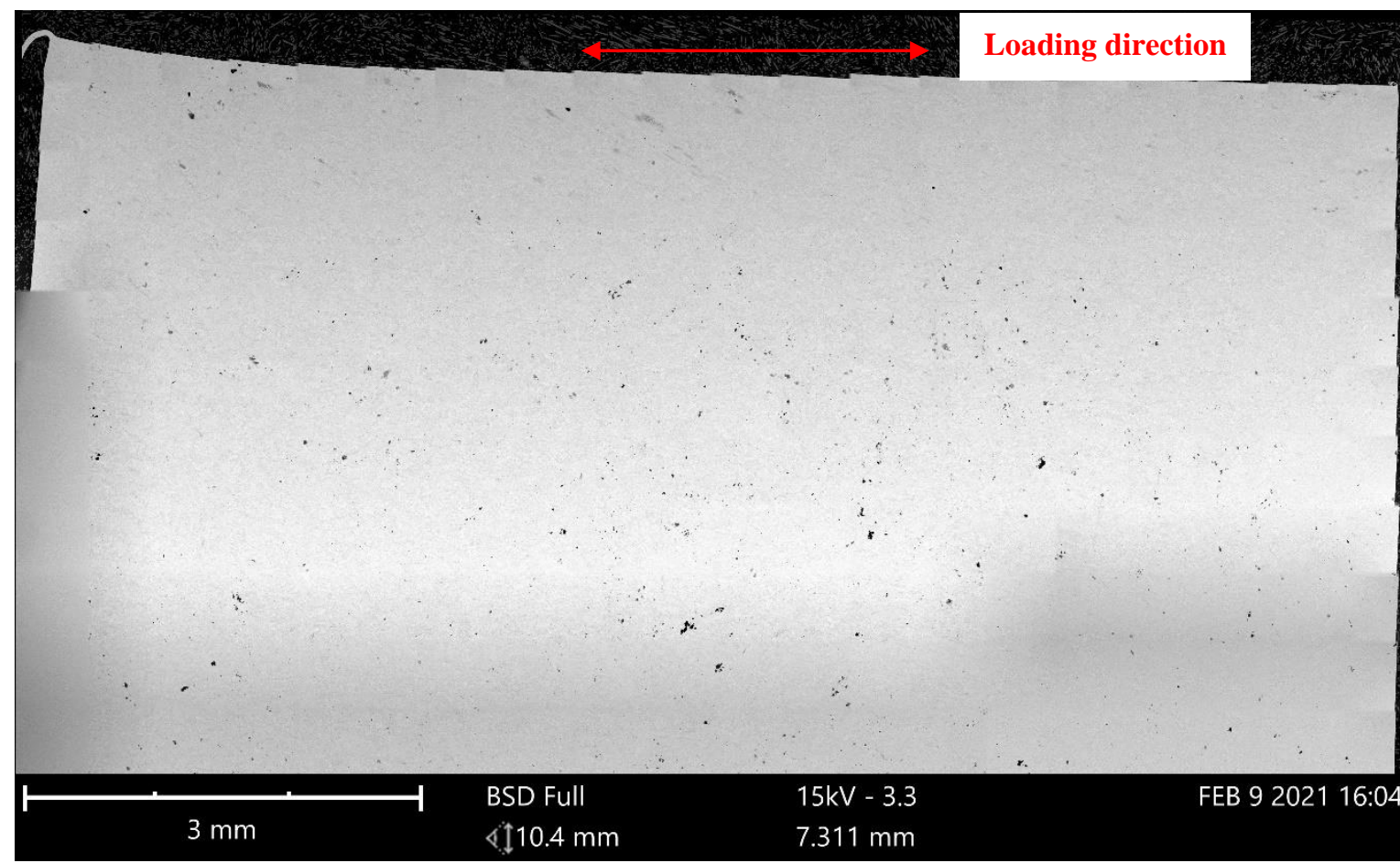

(a)
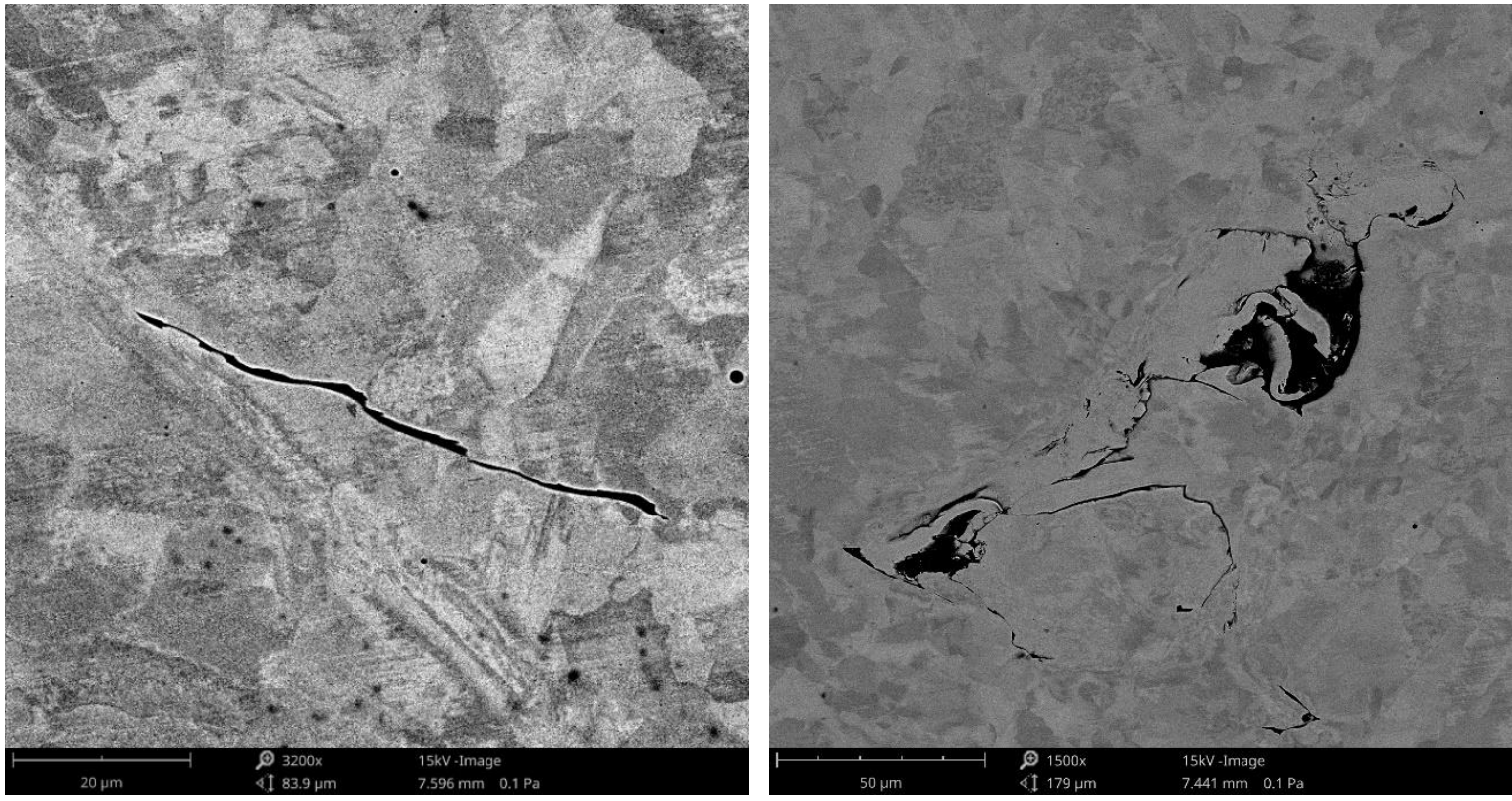

(b)

Figure 4-15. Internal porosity and cracks in the gauge section of the rod specimen, L2-5 after 220 cycles tested at $550^{\circ} \mathrm{C}, 0.5 \%$. 
Figure 4-16 shows multiple cracks initiated at or near surfaces in vertical plate specimen, $8-2 \mathrm{~V}$ tested at $550^{\circ} \mathrm{C}, 0.4 \%$, as often observed in fatigue-fractured specimens. Surprisingly, a surface layer of altered microstructure from bulk was observed at the surfaces of specimen $8-2 \mathrm{~V}$. Further investigation found that the thickness of the surface layer varied between specimens. As shown in Fig. 4-17(a), the thickness of the surface layer is $17 \mu \mathrm{m}$ in vertical plate specimen, $8-2 \mathrm{~V}$, $5 \mu \mathrm{m}$ in vertical plate specimen, $8-4 \mathrm{~V}$, and $12 \mu \mathrm{m}$ in horizontal plate specimen, $3-1 \mathrm{H}$. No surface layers were observed at the surfaces of rod specimens, as shown in Fig. 4-17(b). The formation of surface layers and their effect on fatigue properties of plate specimens remained to be understood.

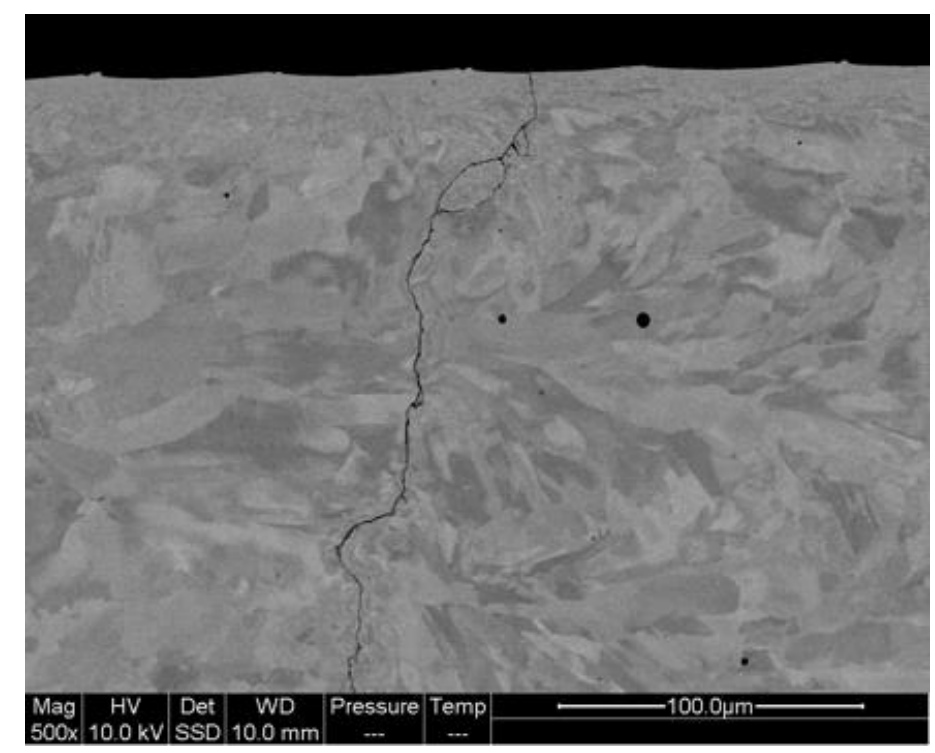

(a)

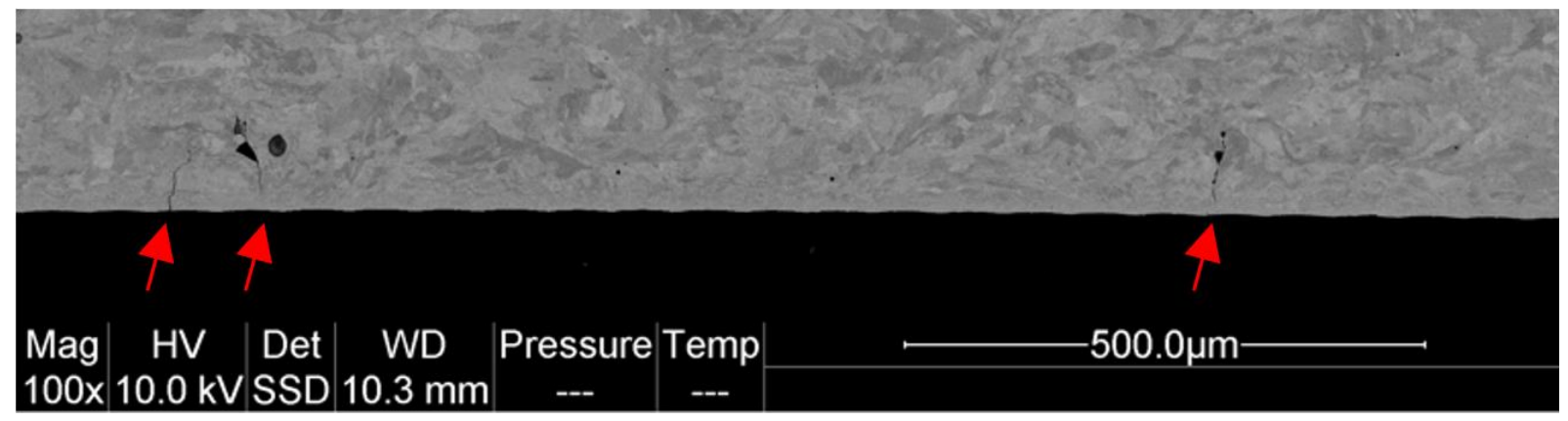

(b)

Figure 4-16. SEM image showing (a) a crack initiates at the sample surface and propagates into the specimen interior and (b) multiple cracks on the surface of vertical plate specimen, 8-2V $\left(550^{\circ} \mathrm{C}, 0.4 \%\right)$. 

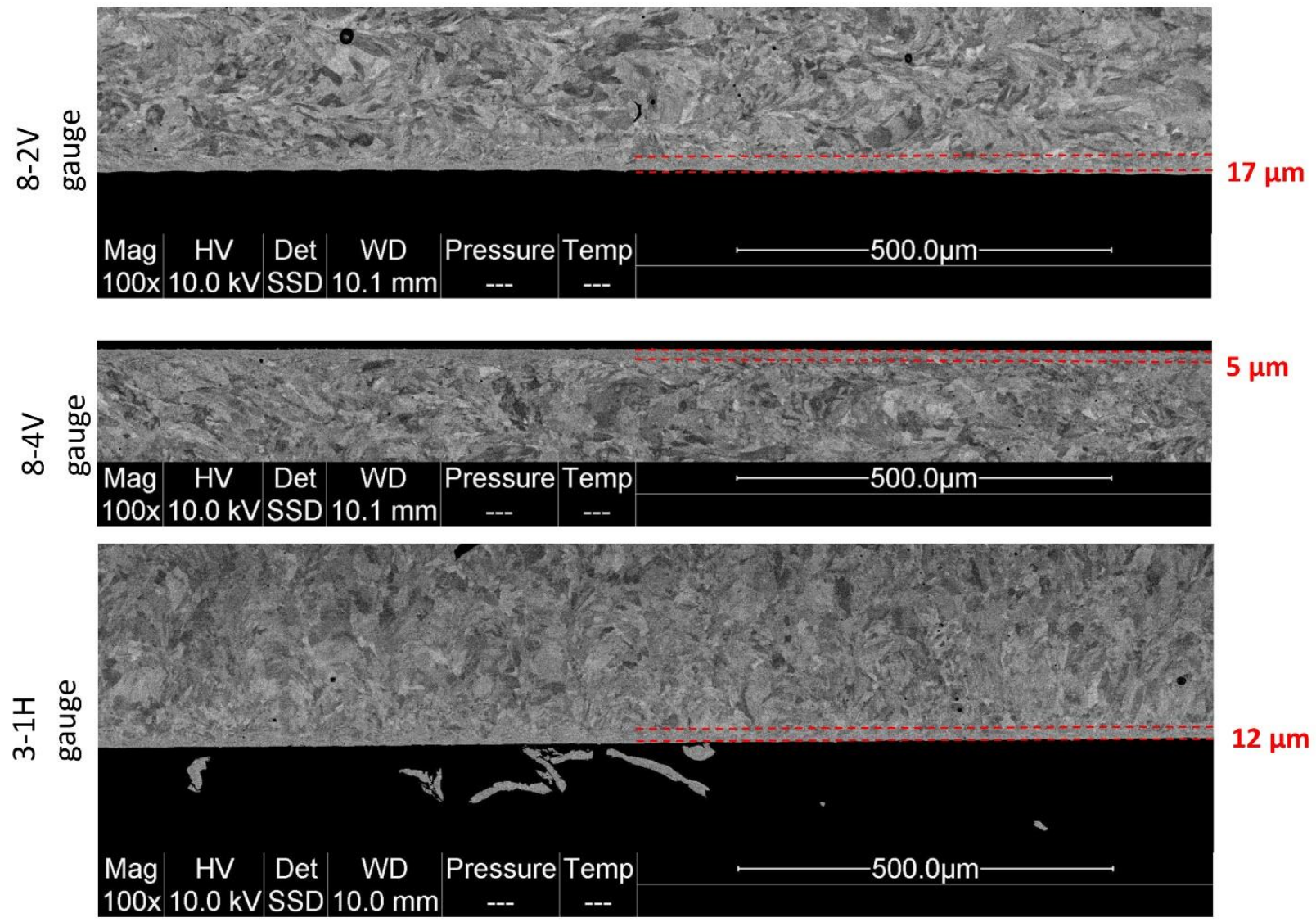

(a)
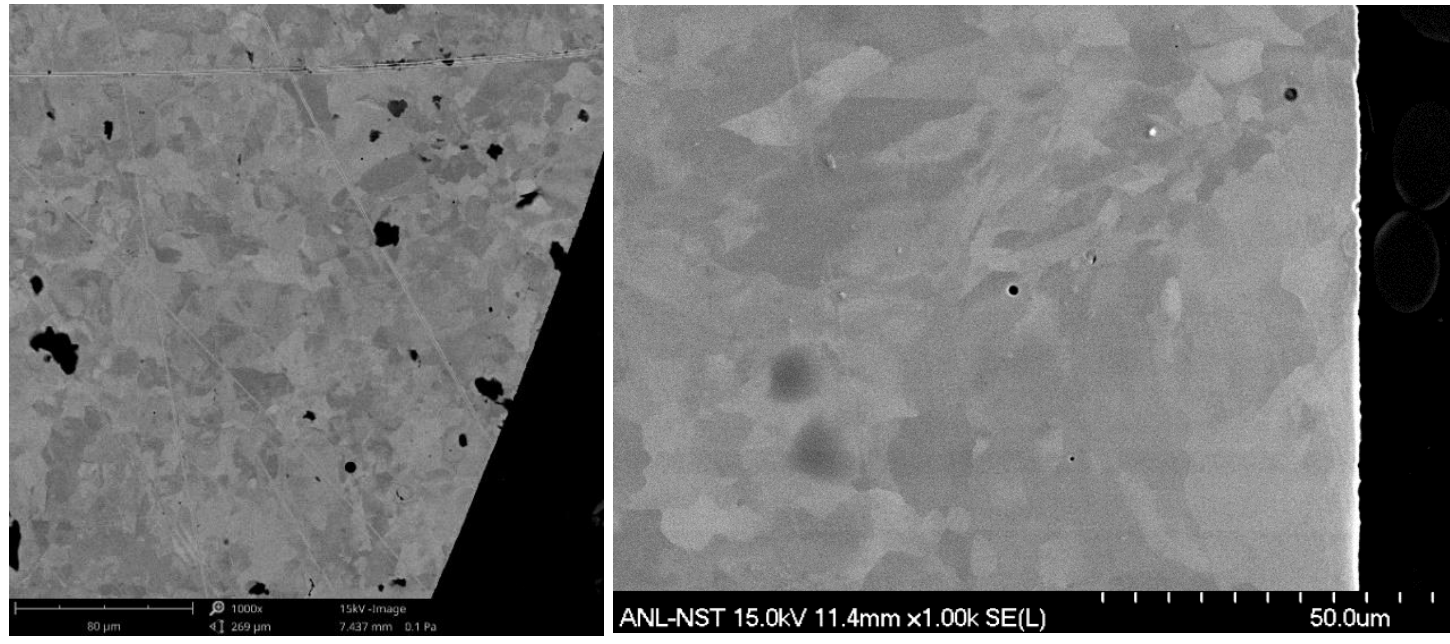

(b)

Figure 4-17. (a) Surface layers observed in the vertical plate specimens, $8-2 \mathrm{~V}\left(550^{\circ} \mathrm{C}, 0.4 \%\right)$ and $8-4 \mathrm{~V}\left(550^{\circ} \mathrm{C}, 0.25 \%\right)$ and the horizontal plat specimen, $3-1 \mathrm{H}\left(550^{\circ} \mathrm{C}, 0.2 \%\right)$ but not in (b) the rod specimen, $\mathrm{L} 2-5\left(550^{\circ} \mathrm{C}, 0.5 \%\right)$. 


\section{$5 \quad$ Evaluation of Tensile and Creep Properties of Printed Plates using Subsized Specimens}

\subsection{Experimental}

To evaluate the creep life of printed plates at specific locations, creep tests were conducted using subsized sheet-type SS-3 specimens shown in Fig. 5-1. Specimens have nominal gauge length of 0.30 ", gauge width of 0.06 " and thickness of 0.03 ". Subsized specimens were machined from plate L2-3, and their locations relative to the fatigue specimens are shown in Fig. 4-3.

Subsized sheet-type SS-3 specimens were also machined from a printed rod, L1-8 of Build 20190315M2. The specimens were oriented with the gauge in parallel with the build direction, and three rows of specimens were machined along the build direction with each row having eight specimens and four each symmetrically situated from the centerline of the cross section of the rod, as shown in Fig. 5-2. To track the location of each specimen, the length of the upper grip section of the specimen was increased by different amounts relative to the length of the lower grip section (instead of equal lengths as in a conventional specimen). Specifically, the upper grip was 0.09" longer than the lower grip in the top row specimens, 0.06 " longer in the middle row specimens, and 0.03 " longer in the bottom row specimens. The location of a specimen within a rod was also tracked by the specimen ID. For example, the ID " $1 \mathrm{~T} 1$ " has the first number " 1 " representing laser 1 mode, the second letter " $T$ " representing the top section of the rod, and the third letter " 1 " showing the location of the specimen in the cross section of the rod (see the cross-section view in Fig. 5-2).

Creep tests were conducted on ATS direct-load frames equipped with a three-zone splittube furnace capable of operation up to $1100^{\circ} \mathrm{C}$. The temperature was monitored by 2 thermocouples with each attached to the grip shoulder section of the specimen. The temperature was maintained to a total variance of $\pm 1^{\circ} \mathrm{C}$. Creep strain was monitored by an averaging extensometer frame mounted on opposite sides of the specimen, and was calculated using the specimen nominal gauge length. All the specimens were tested to rupture.

Tensile tests were also performed using subsized SS-3 specimens in an electromechanical testing system equipped with the Instron Bluehill software. Tests were conducted at 20 and $550^{\circ} \mathrm{C}$ at a nominal strain rate of $1 \times 10^{-3} / \mathrm{s}$ using a set of pin-loading grips. The applied load was recorded by a load cell; the specimen displacement was measured by the crosshead extension. The engineering tensile properties were determined from the analysis of the load and displacement data.

Table 5-1 lists the specimens and testing conditions. 


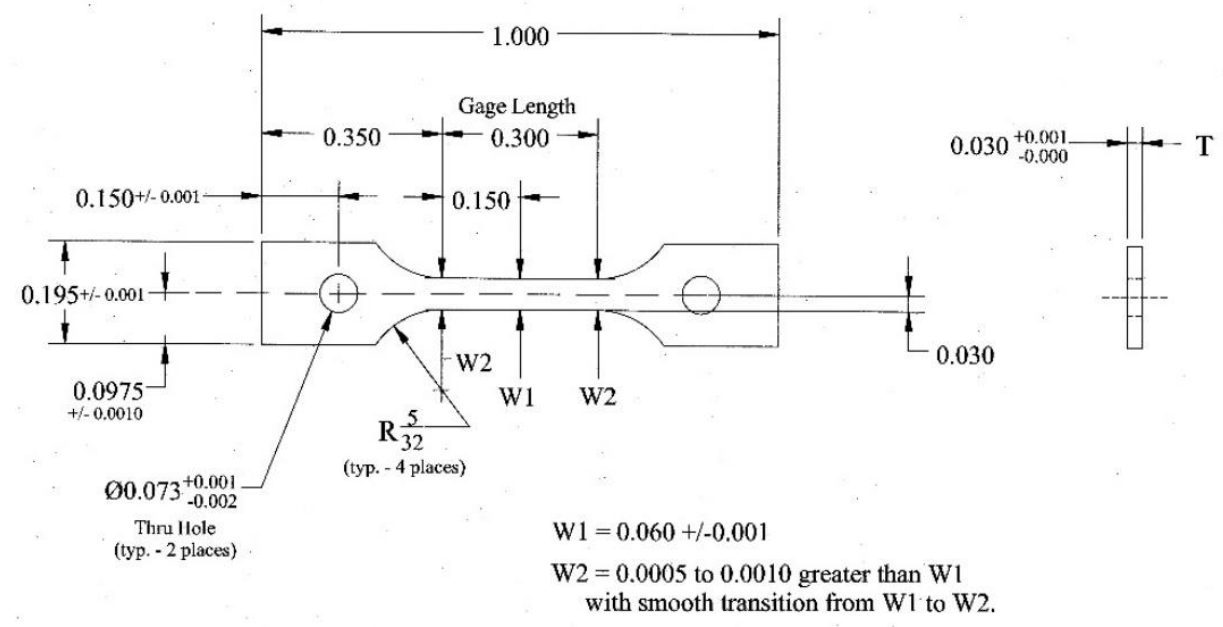

Figure 5-1. Schematic drawing of subsized sheet-type SS-3 specimens (unit: inch).

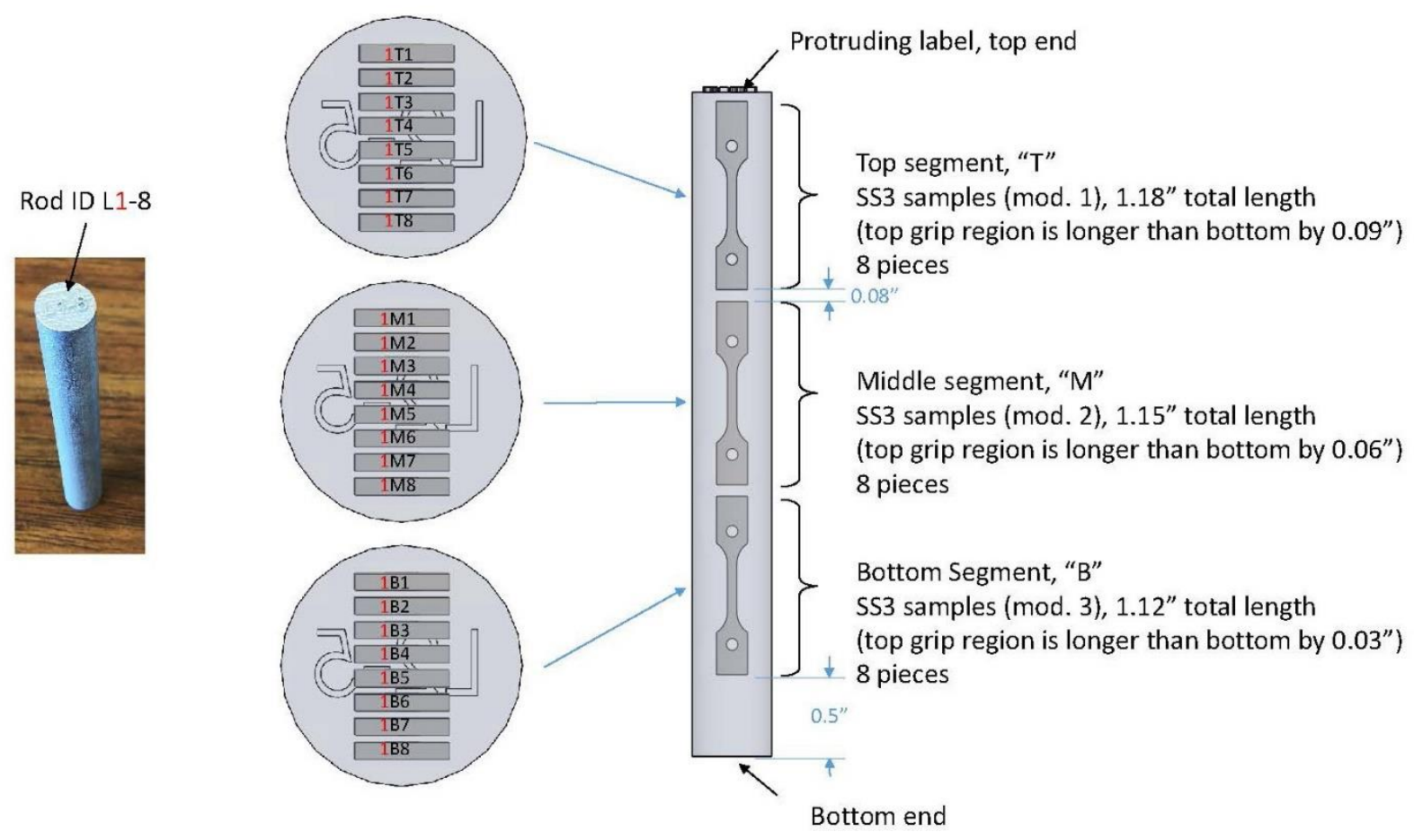

Figure 5-2. Specimen fabrication drawing showing the orientation and location of suszied SS-3 specimens made from rod L1-8. 
Table 5-1. List of subsized SS-3 specimens and testing conditions.

\begin{tabular}{|c|c|c|c|c|c|c|c|}
\hline $\begin{array}{c}\text { Specimen } \\
\text { ID }\end{array}$ & Build \# & $\begin{array}{c}\text { Print } \\
\text { Geometry }\end{array}$ & $\begin{array}{c}\text { Rod/Plate } \\
\text { ID }\end{array}$ & $\begin{array}{c}\text { Test } \\
\text { Type }\end{array}$ & $\begin{array}{c}\text { Temp } \\
\left({ }^{\circ} \mathbf{C}\right)\end{array}$ & $\begin{array}{c}\text { Stress } \\
(\mathbf{M P a})\end{array}$ & $\begin{array}{c}\text { Strain } \\
\text { rate (1/s) }\end{array}$ \\
\hline 3A1 & 20201009M2 & Plate & L2-03 & Creep & 550 & 320 & - \\
\hline 3A2 & $20201009 M 2$ & Plate & L2-03 & Creep & 550 & 300 & - \\
\hline 3A3 & $20201009 M 2$ & Plate & L2-03 & Creep & 550 & 285 & - \\
\hline 3A4 & $20201009 M 2$ & Plate & L2-03 & Creep & 550 & 275 & - \\
\hline 3B1 & $20201009 M 2$ & Plate & L2-03 & Tensile & 550 & - & 0.001 \\
\hline 3B2 & 20201009M2 & Plate & L2-03 & Tensile & 20 & - & 0.001 \\
\hline 1M3 & $20190315 M 2$ & Rod & L1-8 & Creep & 550 & 275 & - \\
\hline 1M6 & $20190315 M 2$ & Rod & L1-8 & Creep & 550 & 285 & - \\
\hline 1M7 & $20190315 M 2$ & Rod & L1-8 & Creep & 550 & 300 & - \\
\hline 1M8 & $20190315 M 2$ & Rod & L1-8 & Creep & 550 & 265 & - \\
\hline 1M4 & $20190315 M 2$ & Rod & L1-8 & Tensile & 550 & - & 0.001 \\
\hline 1M5 & $20190315 M 2$ & Rod & L1-8 & Tensile & 20 & - & 0.001 \\
\hline
\end{tabular}

\subsection{Results}

\subsubsection{Creep Rupture Life}

Figure 5-3 compares the stress-rupture life data obtained using ASTM standard-sized specimens and subsized SS-3 specimens fabricated from printed rods. The specimens were tested at $550^{\circ} \mathrm{C}$ at different stress levels. The subsized specimens showed shorter creep lives than the standard-sized specimens. It appears that the size and shape of the extracted tested specimens is a factor when comparing creep properties of AM materials.

Figure 5-4 shows the creep rupture data for subsized SS-3 specimens fabricated from rod L1-8 of Build 20190315M2 and from plate L2-03 of Build 20201009M2 for AM 316L SS. Again, all the creep tests were conducted at $550^{\circ} \mathrm{C}$. Because of the same size and geometry of creep specimens, it is reasonable to compare the creep life of printed rods and plates. It is shown that plate specimens have relatively longer creep lives than the rod specimens. 


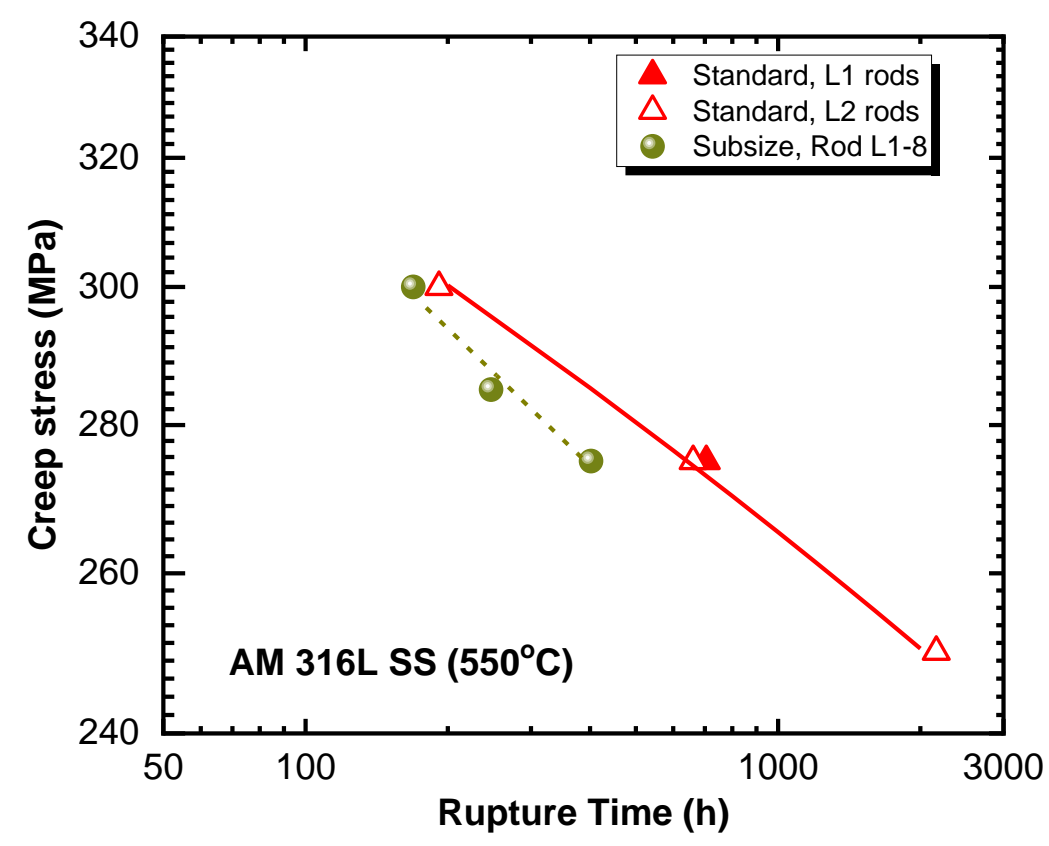

Figure 5-3. Stress-rupture life data of standard-sized and subsized specimens of printed rods for AM 316L SS.

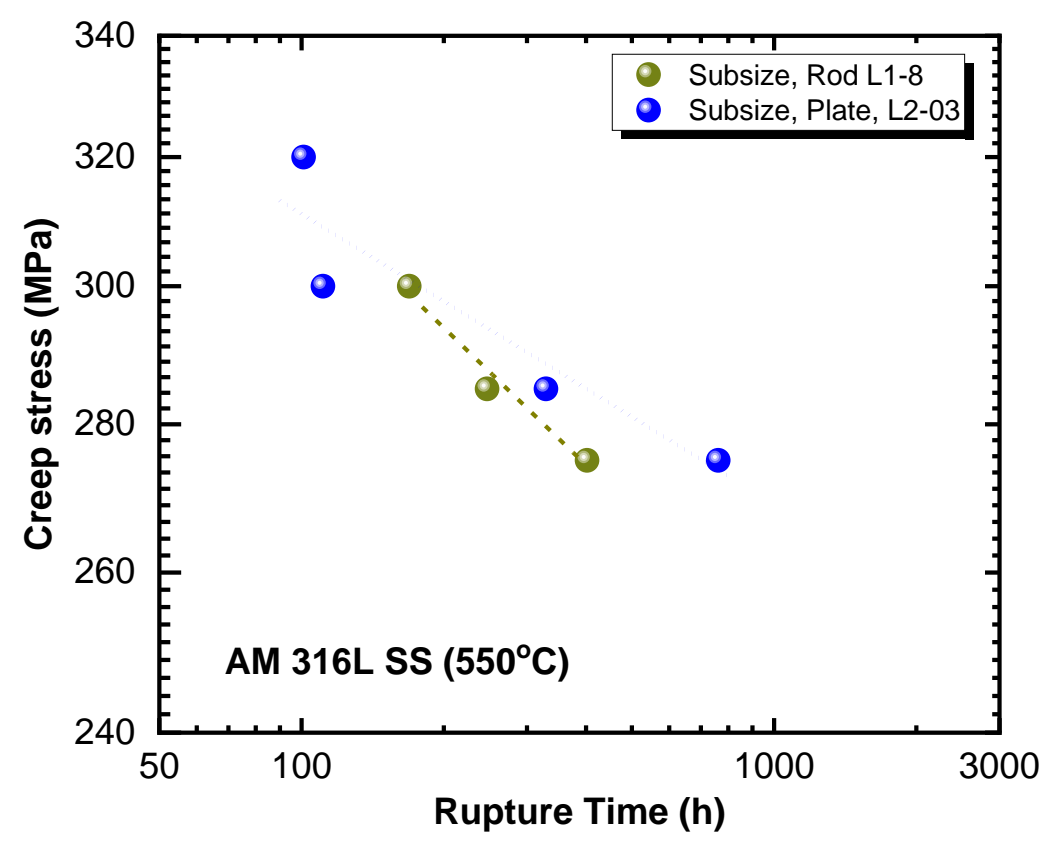

Figure 5-4. Stress-rupture life data of subsized specimens fabricated from rod L1-8 of Build 20190315M2 and from plate L2-03 of Build 20201009M2 for AM 316L SS. 


\subsubsection{Tensile Stress-Strain Curves}

The tensile stress - strain curves are shown in Fig. 5-5 for subsized SS-3 specimens (1M4 and 1M5) fabricated from rod L1-8 and subsized SS-3 specimen (3B1 and 3B2) machined from plate $\mathrm{L} 2-03$ tested at 20 and $550^{\circ} \mathrm{C}$, respectively, at a strain rate of $0.001 \mathrm{~s}^{-1}$. The plate specimens (3B1 and 3B2) have a higher yield stress and an ultimate tensile strength but lower uniform and total elongations than the rod specimen (1M4 and $1 \mathrm{M} 5)$ at both 20 and $550^{\circ} \mathrm{C}$. Both rod and plate specimens show serrations in the $550^{\circ} \mathrm{C}$ flow curves, indicating the dynamic strain aging effect.

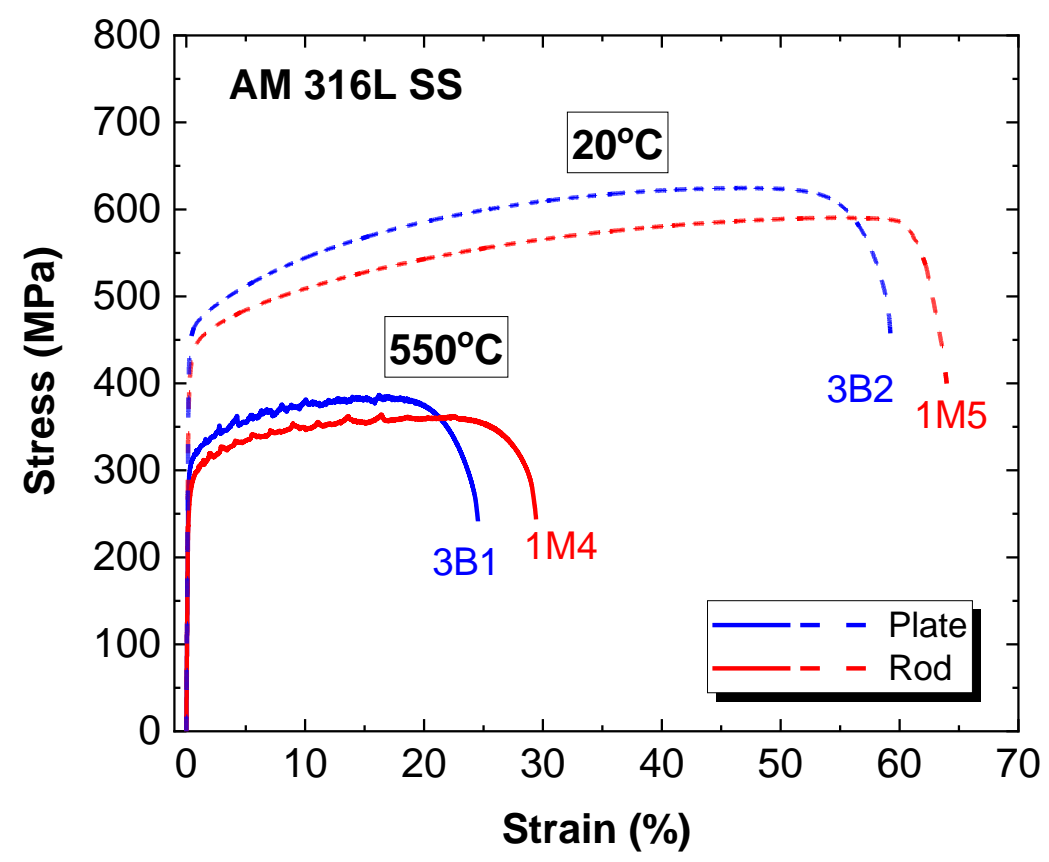

Figure 5-5. Tensile stress-strain curves for rod specimens (1M4 and 1M5) and plate specimens (3B1 and 3B2) tested at 20 and $550^{\circ} \mathrm{C}$ and a strain rate of $0.001 \mathrm{~s}^{-1}$. 


\section{Summary}

Creep and fatigue behavior of 316L stainless steel produced by laser powder bed fusion was investigated. Locations of specimens in the build were carefully tracked such that the testing data can be directly related to location-specific in situ data to establish links between printing process, post-printing treatment, microstructure and mechanical properties.

Creep tests of AM 316L SS were conducted at temperatures of 550, 575, 600, and $650^{\circ} \mathrm{C}$ and stresses between 175 and $300 \mathrm{MPa}$ using ASTM standard-sized specimens fabricated from rods of Builds 20190308M2 and 20190315M2. Rods were printed by either or a combination of two lasers of the dual-laser system of a Concept Laser-M2 printer to evaluate the consistency across the build plate. The short-term creep tests showed insignificant batch variability between the specimens made by two laser systems. All the creep curves of AM 316L SS were dominated by accelerated creep. The minimum creep rate was achieved at the early stage of the test, typically at a creep strain of $<1 \%$. The normalized minimum creep rate - stress plot can be described by a single power-law relationship with the stress exponent, $\mathrm{n} \sim 12$. The high stress dependence of the creep rate in AM 316L SS was attributed to the dislocation cell structure resulting from the printing process. AM 316LSS had a relatively shorter creep life when compared to the literature data of conventionally-made 316 SS (CM 316 SS), despite the fact that AM 316L SS shows no inferior creep ductility compared to CM 316 SS. Creep analysis suggests that the creep life of AM 316L SS may be improved by reducing internal porosity from printing and/or stabilizing dislocation cell structure during creep.

Creep specimens fabricated from rods were heat treated at six different temperatures, namely, $650^{\circ} \mathrm{C}, 700^{\circ} \mathrm{C}, 750^{\circ} \mathrm{C}, 800^{\circ} \mathrm{C}, 900^{\circ} \mathrm{C}$ and $1050^{\circ} \mathrm{C}$. The heat-treated specimens were creep-tested under the same condition, $550^{\circ} \mathrm{C} / 275 \mathrm{MPa}$ to evaluate the effect of post-build heat treatment on the creep behavior of AM 316L SS. In the temperature range of $650-750^{\circ} \mathrm{C}$, dislocation density within cells, and cell size and wall thickness were affected by the heat treatment, while elemental segregation at boundaries remained unchanged and Mn-enriched Si oxide particles remained stable. In the temperature range of $750-900^{\circ} \mathrm{C}$, concurrent changes were observed in dislocation cell structures, elemental segregation and oxide particles. The $1050^{\circ} \mathrm{C}$ heat treatment removed cell structures and boundary solute segregations, leading to formation of equiaxed grains; Mn-enriched Si oxide particles in the as-built specimen were replaced by more stable Mn-enriched Cr oxides. The creep life of AM 316L SS increased after the heat treatment at $650^{\circ} \mathrm{C}$ and then decreased with increasing temperature up to $900^{\circ} \mathrm{C}$ where cell/subgrain structures still existed. The creep rate and creep elongation followed an opposite trend. The creep rate can be correlated with the structural parameters of cell/subgrain size and cell wall/boundary thickness and can be rationalized by different strengthening mechanisms of dislocation cells and subgrains. The heat treatment affected strongly the primary and secondary creep but had a minimal effect on the tertiary creep of AM $316 \mathrm{~L} \mathrm{SS}$. The $650^{\circ} \mathrm{C} 1 \mathrm{~h}$ was considered as the optimum heat treatment condition for creep resistance of AM 316L SS.

Fatigue properties of AM 316L SS were evaluated for two different print geometries, namely, rod and plate, and in two build orientations of printed plates, horizontal vs. vertical, using ASTM standard-sized specimens. All the fatigue tests were conducted at $550^{\circ} \mathrm{C}$ under a constant 
total strain amplitude in fully reversed $(\mathrm{R}=-1)$ strain control. Compared with literature data of wrought 316 SS, rod specimens of AM 316L SS had shorter fatigue lives, while plate specimens had comparable fatigue lives to wrought 316 SS at lower strain amplitudes but shorter lives at higher strain amplitudes. The specimens in two build orientations appeared to behave similarly, however, the fatigue results were complicated by the surface layers of altered microstructure from bulk with varied thicknesses in different specimens. Both surface cracks and internal cracks were observed, implying the adverse effect of internal defects resulting from printing. Cyclic softening was observed under all testing conditions after the initial transient stage. There was a strong dynamic strain effect under cyclic loading, particularly at high strain amplitudes. Cell structures remained stable under fatigue loading.

Creep behavior of printed plates was evaluated using subsized SS-3 specimens at $550^{\circ} \mathrm{C}$. Preliminary results showed specimens from a printed plate had somewhat longer creep lives than specimens from a printed rod. Tensile tests conducted at 20 and $550^{\circ} \mathrm{C}$ on subsized specimens showed that specimens from a printed plate had a higher yield stress and an ultimate tensile strength but lower uniform and total elongations than specimens from a printed rod. Future work is to further validate creep data of subsized specimens to obtain location-specific creep properties particularly for components with complex structure. Effort will also be made to estimate hightemperature fatigue properties using tensile data for AM component qualification. 


\section{Acknowledgement}

Work was supported by the Transformational Challenge Reactor Program funded by the U.S. Department of Energy, Office of Nuclear Energy under Contract DE-AC02-06CH11357. Materials were provided by Oak Ridge National Laboratory. Use of the Center for Nanoscale Materials, an Office of Science user facility, was supported by the U.S. Department of Energy, Office of Science, Office of Basic Energy Sciences, under Contract No. DE-AC02-06CH11357. This research used resources of the Advanced Photon Source, a U.S. Department of Energy (DOE) Office of Science User Facility operated for the DOE Office of Science by Argonne National Laboratory under Contract No. DE-AC02-06CH11357. We would like to acknowledge Chase Joslin, Ryan Duncan and Luke Scime for specimen fabrication at ORNL, and Peter Kenesei for assistance in X-ray tomography reconstruction at ANL. Kurt Terrani, Paquit Vincent, T. S. Byun are thanked for providing useful direction and discussions during this effort.

\section{REFERENCES}

1. K.A. Terrani "Accelerating the Deployment of Advanced Nuclear Energy Systems." Nuclear News, Apr. 2020, 34-37.

2. Z. Sun, X. Tan, S.B. Tor, C. K. Chua, "Simultaneously enhanced strength and ductility for 3D-printed stainless steel 316L by selective laser melting," NPG Asia Materials 10 (2018) 127.

3. Y.M. Wang, T. Voisin, J.T. McKeown, J. Ye, N.P. Calta, Z. Li, Z. Zeng, et al., "Additively manufactured hierarchical stainless steels with high strength and ductility", Nature Materials 17 (2018) 63.

4. M. D. Shamsujjoha, S. R. Agnew, J. M. Fitz-gerald, W. R. Moore, T. A. Newman, "High strength and ductility of additively manufactured 316L stainless steel explained," Metall. Mater. Trans. 49A (2018) 3011.

5. Meimei Li, Xuan Zhang, Wei-Ying Chen, T.S. Byun, "Creep behavior of 316 L stainless steel manufactured by laser powder bed fusion,” J. Nucl. Mater. 548 (2021) 152847.

6. J. Simpson, J. Haley, C. Cramer, O. Shafer, A. Elliott, W. Peter, L. Lover, R. Dehoff, "Considerations for application of additive manufacturing to nuclear reactor core components," ORNL/TM-2019-1190, Oak Ridge National Laboratory (2019).

7. B.R. Betzler, B. J. Ade, A. J. Wysocki, P. K. Jain, P. C. Chesser, M. S. Greenwood, K. A. Terrani, “Transformational Challenge Reactor Preconceptual Core Design Studies." Nuclear Engineering and Design 367 (2020) 110781.

8. R. Singh, A. Gupta, et al., "Powder bed fusion process in additive manufacturing: an overview," Materials Tosay 26 (2020) 3058.

9. P. Bajaj, A. Hariharan, A. Kini, P. Kurnsteiner, D. Raabe, E. A. Jagle, "Steels in additive manufacturing: a review of their microstructure and properties," Mater. Sci. \& Eng. A 772 (2020) 138633.

10. D. Herzog, V. Seyda, C. Emmerlmann, "Additive manufacturing of metals," Acta Mater. 117 (2016) 371.

11. M. L. Montero-Sistiaga, M. Godino-Martinez, K. Boschmans, J. Kruth, J. V. Humbeeck, K. Vanmeensel, "Microstructure evolution of 316L produced by HP-SLM (high power selective laser melting)" Add. Manuf. 23 (2018) 402. 
12. E. Garlea, H. Choo, C. C. Sluss, M.R. Koehler, R. L. Bridges, X. Xiao, Y. Ren, B. H. Jared, "Variation of elastic mechanical properties with texture, porosity, and defect characteristics in laser powder bed fusion 316L stainless steel" Mater. Sci. Eng. A 763 (2019) 138032.

13. A. S. Wu, D. W. Brown, M. Kumar, G. F. Gallegos, W. E. King, "An Experimental Investigation into Additive Manufacturing-Induced Residual Stresses in 316L Stainless Steel” Metall. Mat. Trans. A 45 (2014) 6260.

14. J. L. Bartlett, X. Li, "An overview of residual stresses in metal powder bed fusion" Add. Manuf. 27 (2019) 131.

15. K. Saeidi, X. Gao, Y. Zhong, Z.J. Shen, "Hardened austenite steel with columnar sub-grain structure formed by laser melting," Mater. Sci. Eng. A 625 (2015) 221-229.

16. E. Yasa, J.-P. Kruth, "Microstructural investigation of selective laser melting 316L stainless steel parts exposed to laser re-melting," Procedia Eng. 19 (2011) 389-395.

17. Y. Zhong, L. Liu, S. Wikman, D. Cui, Z. Shen, "Intragranular cellular segregation network structure strengthening 316L stainless steel prepared by selective laser melting," J. Nucl. Mater. 470 (2016) 170.

18. T. Kurzynowski, K. Gruber, W. Stopyra, B. Kuznicka, E. Chlebus, "Correlation between process parameters, microstructure and properties of $316 \mathrm{~L}$ stainless steel processed by selective laser melting" Mater. Sci. Eng. A 718 (2018) 64.

19. O. Salman, C. Gammer, A. Chaubey, J. Eckert, S. Scudino, "Effect of heat treatment on microstructure and mechanical properties of 316L steel synthesized by selective laser melting," Mater. Sci. Eng. A (2019).

20. P. Deng, H. Yin, M. Song, D. Li, Y. Zheng, B. C. Prorok, X. Lou, "On the Thermal Stability of Dislocation Cellular Structures in Additively Manufactured Austenitic Stainless Steels: Roles of Heavy Element Segregation and Stacking Fault Energy," JOM 72 (2020) 4232.

21. N. Chen, G. Ma, W. Zhu, A. Godfrey, Z. Shen, G. Wu, X. Huang, "Enhancement of an additive-manufactured austenitic stainless steel by post-manufacture heat-treatment," Mater. Sci. \& Eng. A 759 (2019) 65.

22. T. Voisin, J. Forien, A. Perron, S. Aubry, N. Bertin, A. Samanta, A. Baker, Y. M. Wang, "New insights on cellular structures strengthening mechanisms and thermal stability of an austenitic stainless steel fabricated by laser powder-b e d-fusion," Acta Mater. 203 (2021) 116476.

23. T. Ronneberg, G.M. Davies, P. A. Hooper, "Revealing relationships between porosity, microstructure and mechanical properties of laser powder bed fusion 316L stainless steel through heat treatment," Materials \& Design 189 (2020) 108481.

24. E. Tascioglu, Y. Karabulut, Y. Kaynak, "Influence of heat treatment temperature on the microstructural, mechanical, and wear behavior of 316L stainless steel fabricated by laser powder bed additive manufacturing," Inter. J. Adv. Manuf. Tech. 107 (2020) 1947.

25. D. Kong, X. Ni, C. Dong, L. Zhang, C. Man, J. Yao, K. Xiao, X. Li, "Heat treatment effect on the microstructure and corrosion behavior of 316L stainless steel fabricated by selective laser melting for proton exchange membrane fuel cells," Electrochimica Acta 276 (2018) 293.

26. W. Shin, B. Son, W. Song, H. Sohn, H. Jang, W. Kim, C. Park, "Heat treatment effect on the microstructure, mechanical properties, and wear behaviors of stainless steel 316L prepared via selective laser melting," Mater. Sci. Eng. A 8-6 (2021) 140805. 
27. P. Krakhmalev, G. Fredriksson, K. Svensson, I. Yadroitsev, I. Yadroitsava, M. Thuvander, R. Peng "Microstructure, solidification texture, and thermal stability of 316L stainless steel manufactured by laser powder bed fusion," Metals 8 (2018) 643.

28. K. Saeidi, X. Gao, F. Lofaj, L. Kvetkova, Z. J. Shen, "Transformation of austenite to duplex austenite-ferrite assembly in annealed stainless steel 316L consolidated by laser melting," J. Alloys Comp. 633 (2015) 463.

29. K. M. Bertsch, G. M. de Bellefon, B. Kuehl, D. J. Thoma, "Origin of dislocation structures in an additively manufactured austenitic stainless steel 316L" Acta Mater. 15 (2020) 19.

30. T. Pinomaa, M. Lindroos, M. Walbruhl, N. Provatas, A. Laukkanen, "The significance of spatial length scales and solute segregation in strengthening rapid solidification microstructures of 316L stainless steel" Acta. Mater. 184 (2020) 1.

31. Z. Li, B. He, Q. Guo, "Strengthening and hardening mechanisms of additively manufactured stainless steels: The role of cell sizes," Scripta Mater. 177 (2020) 17.

32. K. Saeidi, L. Kvetkova, F. Lofaj, Z. Shen, “Austenitic stainless steel strengthened by the in situ formation of oxide nanoinclusions" RSC Advances 5 (2015) 20747.

33. X. Zhang, P. Kenesei, J. Park, J. Almer, M. Li, "In situ high-energy X-ray study of deformation mechanisms in additively manufactured 316L stainless steel," J. Nucl. Mater. 549 (2021) 152874.

34. K.G. Field, J. Simpson, M.N. Gussev, H. Wang, M. Li, X. Chen, T. Koyanagi, K. Kane, A.M. Rossy, M. Balooch, K.A. Terrni, "Handbook of advanced manufactured material properties from TCR structure builds at ORNL - FY19," ORNL/TM-2019/1328 (2019).

35. G. Sasikala, M.D. Mathew, K. B. S. Raom S.L. Mannan, "Creep deformation and fracture behavior of Type 316 and 316L(N) stainless steels and their weld metals," Metall. Mater. Trans. 31A (2000) 1175.

36. C. R. Brinkman, "Elevated-temperature mechanical properties of an advanced Type 316 stainless steel," ASME Pressure and Piping Conference, Boston, MA (US), 08/01/1999-08/05/1999.

37. H.J. Kestenbach, W. Krause, T.L. da Silveira, "Creep of 316 stainless steel under high stresses," Acta Metall. 26 (1978) 661.

38. K.D. Challenger and J. Moteff, "Quantitative characterization of the substructure of AISI 316 stainless steel resulting from creep," Metall. Trans. 4 (1973) 749.

39. H.J. Kestenbach, T.L. Da Silveira, S.N. Monteiro, "On subgrain formation during creep pf 316 stainless steel," Metall. Trans. 7A (1976) 155.

40. L.J. Cuddy, "Internal stresses and structures development during creep," Metall. Trans. 1 (1970) 395.

41. S. N. Monteiro, F. S. da Luz, W. A. Pinheiro, et al "Creep parameters and dislocation substructure in AISI 316 austenitic stainless steel from $600^{\circ} \mathrm{C}$ to $800^{\circ} \mathrm{C}$," Mater. Res. 20 (2017) 231.

42. O.D. Sherby and P.M. Burke, "Mechanical Behavior of Crystalline Solids at Elevated Temperature," Prog. Mater. Sci. 13 (1968) 325.

43. H.J. Frost and M.F. Ashby, Deformation mechanism aps: the plasticity and creep of metals and ceramics, Pergamon Press, 1982.

44. R. W. Hertzberg, Deformation and Fracture Mechanics of Engineering Materials, 4th Ed., John Wiley \& Sons Inc., 1995.

45. O. D. Sherby, R. H. Klundt, A. K. Miller, "Flow stress, subgrain size, and subgrain stability at elevated temperature," Metall. Trans. 8A (1977) 843. 
46. D. J. Michel, J. Moteff, A. J. Lovell, "Substructure of Type 316 stainless steel deformed in slow tension at temperatures between $21^{\circ}$ and $816^{\circ} \mathrm{C}$," Acta Metall. 21 (1973) 1269.

47. S. V. Raj, I. S. Iskovitz, A. D. Freed, "Modeling the role of dislocation substructure during class M and exponential creep," in Unified Constitutive Laws of Plastic Deformation, Eds. A. S. Krausz and K. Krausz, Academic Press, San Diego, 1996, p. 343.

48. J.A. Mazza, G. Willoughby, "Structural changes and creep mechanisms in type 316 steel at $600^{\circ} \mathrm{C}$," Journal of the Iron and Steel Institute. 204 (1966) 718.

49. Naveena, P. Parameswaran, K. Laha, M. D. Mathew (2014), "Study on creep deformation mechanism of $316 \mathrm{LN}$ stainless steel from impression creep tests," Materials at High Temperatures, 31:2, 180-184.

50. G. Sasikala, M.D. Mathew, K. B. S. Raom S.L. Mannan, "Creep parameters and dislocation substructure i AISI 316 austenitic stainless steel from $600^{\circ} \mathrm{C}$ to $800^{\circ} \mathrm{C}$," Mater. Res. 20 (2017) 231.

51. R.J. Fields, T. Weerasooriya, M.F. Ashby, "Fracture mechanisms in pure iron, two austenitic steels, and one ferritic steel," Metall. Trans. 11A (1980) 1980.

52. G. H. Edward, M. F. Ashby, "Intergranular fracture during power-law creep," Acta Metall. 27 (1979) 1505.

53. F. C. Monkman and N. J. Grant, Proc. ASTM 56 (1956) 593.

54. S. H. Goods and L.M. Brown, "The nucleation of cavities by plastic deformation," Acta Metall. 27 (1979) 1.

55. A. Argon, I. W. Chen and C. W. Lau, in R. M. N. Pelloux and N. Stoloff (eds.), Creep, Fatigue and Environment Interactions, AIME, Warrendale, PA, 1980.

56. F. H. Bhuiyan and R. S. Fertig III, in Creep and Fatigue in Polymer Matrix Composites (2nd Ed.), 2019.

57. S. J. Fariborz, D. G. Harlow, T. J. Delph, "Intergranular creep cavitation with time-discrete stochastic nucleation," Acta Metall. 7(1986) 1433.

58. B. Ancker, T. H. Hazlett, E. R. Parker, "Relationship between Small-Angle Dislocation Boundaries and Creep" J. App. Phys. 27 (1956) 333.

59. A. J. Birnbaum, J. C. Steuben, E. J. Barrick, A. P. Iliopoulos, J. G. Michopoulos, "Intrinsic strain aging, $\Sigma 3$ boundaries, and origins of cellular substructure in additively manufactured 316L" Add. Manuf. 29 (2019) 100784.

60. D. L. Holt, “Dislocation cell formation in metals,” J. App. Phys. 41 (1970) 3197.

61. E. I. Galindo-Nava, P.E. J. Rivera-Diaz-del-Castillo, "A thermodynamic theory for dislocation cell formation and misorientation in metals" Acta Mater. 60 (2012) 4370.

62. M. Tamura, "Relation between sub-grain size and dislocation density during steady-state dislocation creep of polycrstalline cubic metals," J. Mater. Sci. Res. 7 (2018) 26.

63. F. Yan, W. Xiong, E. Faierson, G. B. Olson, "Characterization of nano-scale oxides in austenitic stainless steel processed by powder bed fusion," Script Mater. 155 (2018) 104.

64. H. Mughrabi, "Dislocation wall and cell structures and long-range internal stresses in deformed metal crystals," Acta Metall. 9 (1983) 1367.

65. H. Mughrabi, T. Ungar, W. Kienle, M. Wilkens, "Long-range internal stresses and asymmetric Xray line-broadening in tensile-deformed [001]-orientated copper single crystals," Phil. Mag. A 53 (1986) 793.

66. H. Mughrabi, "A two-parameter description of heterogeneous dislocation distributions in deformed metal crystals," Mater. Sci. Eng. 85 (1987) 15. 
67. A. Orlova, "Subgrain size in view of the composite model of dislocation structure," Mater. Sci. Eng. A297 (2001) 281.

68. A. W. Thompson, "Substructure strengthening mechanisms," Metall. Trans. A 8A (1977) 833.

69. Y.K. Lee , S.J. Lee , J. Han , “Critical assessment 19: stacking fault energies of austenitic steels," Mater. Sci. \& Tech. 32 (2016) 1.

70. Tavassoli, Ali Asghar, "Effect of Neutron Radiation on Mechanical Properties of Permanent near Core Structures", ASTM STP 1046 (1990), p. 684.

71. M. S. Pham, S. R. Holdsworth, "Dynamic strain aging of AISI 316L during cyclic loading at $300^{\circ} \mathrm{C}$ : mechanism, evolution, and its effect," Mater. Sci. Eng. A 556 (2012) 122. 


\section{Argonne}

Nuclear Science and Engineering Division

Argonne National Laboratory

9700 South Cass Avenue, Bldg. 401

Argonne, IL 60439

www.anl.gov 